Semmelweis Orvostudományi Egyetem

Honvéd- Katasztrófa-Rendvédelem-orvostani Tanszék csoport

\title{
A Magyar Néphadsereg Egészségügyi Szolgálatának története 1980-1989 (II. rész)
}

\section{Dr. Svéd László ny. orvos altábornagy, PhD}

Kulcsszavak: Magyar Néphadsereg, katona-egészségügy, katonai kórházak, egészségügyi szolgálat, szürővizsgálat, egészségnevelés, közegészségügy-járványügy,

MN szanatóriumai, ösztöndíjas, rekonstrukció, csapattagozat, helyörségi csapatrendelö, szervezési feladatok, kondicionálás

Az alaprendeltetést, azaz a háborús alkalmazást, készenlétet és az ezekre való felkészülést és feltételrendszerét bemutató $I$. rész után, most az egészségügyi szolgálatnak a mindennapok speciális - a haderő más szolgálataira nem jellemző - feladatait, nevezetesen az igényjogosult és bizonyos okok miatt a polgári lakosság egyre növekvő számú állományának a gyógyító-megelöző ellátása szervezése és végrehajtása emlékeit mutatom be a korabeli dokumentumok alapján. Ebböl a szempontból is jelentős ez az időszak, hisz a későbbiekben meghatározó infrastrukturális beruházások, a béke és háborús eszközpark megújítása ekkor történt. Jelentős előrelépés következett be a megelőző és kutató tevékenység fejlesztése terén is, ami közvetve szintén a háborús felkészülés részét képezte.

A mindennapok egészségügye

a Magyar Néphadseregben az 1980-89 közötti időszakban

A béke időszaki tevékenységek jelentős része az alaprendeltetési feladatokra irányult. Viszont bátran kijelenthetö az is, hogy az igencsak jelentős nagyságrendü és feladatú központi tagozat mindennapos müködtetése nem volt egyszerü feladat. Mindezeket bonyolították az alapellátás állandósult infrastrukturális és személyi feltételrendszerének anomáliái.
Ugyanakkor a katona-egészségügy társadalmi megítélése sokkal jobb volt, mint általában a hadseregé, amely sok esetben jelentős inspirációt jelentett a szolgálatnak. Mindezért sokan sokat tettek, és ez a tény szintén mindenütt tetten érhető az 1980-as évek Néphadseregének egészségügyében.

A korabeli dokumentumok idörendi áttekintése a fenti megállapításokat egyértelmüen alátámasztják. Ezeket a megitéléseket és változásokat néhány társadalmi és a hadsereg belső értékrendjében 
történő változás is segítette. 1980-tól a kötelező sorkatonai szolgálati időt 18 hónapra csökkentették, $3 \times 6$ hónapos váltásban. A bevonulási idő csökkentése végett a tartalékosokat általában meghatározott körzetekből hívták be, valamint a hadiruházatot is megkapták és behíváskor már abban vonultak be. A 80-as évek elejére szolgálatot teljesítő tisztek több mint 60\%-a 1956 után került a hadseregbe. 1983-ban a tisztikar átlagéletkora hozzávetőlegesen 40 év volt, a 26-35 évesek aránya $30 \%$ körül mozgott. Az egyetemet végzet tisztek aránya a 60 -as évek 20\%-áról a 80-as évekre 60\%-ra nőtt [24].

Mindezek fényében tekintsük át az évtizedet a fentiek irányába ható különbözö feladatok, intézkedések, átalakitások, struktúraváltozások, személyügyi feltétel rendszerek, a gyógyitó munka javitását célzó intézkedések és a megvalósulásuk tükrében.

A betegek szállítása, kísérése, a mütőssegédi és különböző betegek körüli munka megoldása mindig jelentős nehézséget jelentett. 1980 elején ezt áthidalandóan adta ki a MN Hadtáp Főnök a 32/1980. számú „A Magyar Néphadsereg kórházaiban utókezelő részleg szervezéséröl" címü intézkedést. Ebben legalizálták a kórházban hosszú ideig munkaterápián lévő - gyakorlatilag a fenti feladatokat végző - sorkatonák helyzetét. „Az MN KKK 30, az MN 1. KK 15, a vidéki kórházakban 10-10 ágyat biztosítanak” erre a feladatra. A „sorállományú katona betegek kórházi utókezelésére szolgáló részleg szervezésével az aktív gyógykezelést már nem igénylő, de még néhány hétig kórházi utókezelést igénylő betegek elhelyezése munkaterápiával kiegészítve" volt a hivatalos indok. Érdekes módon az intézkedés utalt arra is, hogy „Amennyiben a beteg a munkaterápiás programban való részvétele ellen valami- lyen okból tiltakozik - az egyéb gyógymódokhoz hasonlóan - nem kényszerítheto"' [20].

$A z$ alapellátás szempontjából a korszak legfontosabb és legátfogóbb szabályzatát az MN HF 68/1980. számú intézkedése léptetette hatályba 1980. január 01-től, amely az alapellátás bibliája lett a „Csapathadtáp Szabályzat 4. rész, az állandó harckészültség időszakában egészségügyi szolgálat" címmel [22]. A szabályzat tartalmazta a csapat-egészségügyi szolgálat szervezetét, feladatait, a benne szereplő minden egyes szolgálati személyre lebontva, a gyógyító-megelőző és gondozó munka összes feladatát, a szolgálat tagjainak a betegellátással kapcsolatos magatartását, a közegészségügyi-járványügyi és környezetvédelmi munka néphadseregi követelményeit, az egészségügyi anyagellátás és az egészségügyi technikai eszközbiztosítás rendszerét, valamint az alapellátás tervezését, nyilvántartását, a jelentések rendjét. A mellékletekben, az összes, ebben az időszakban elrendelt dokumentáció, jelentés, nyilvántartás, kiképzési okmány felsorolásra került. A szabályzatot 1990ben újra helyesbítve és pontosítva kiadták a 106/1989. (HK.28.) HM számú utasítással hatályba léptetve [20].

$\mathrm{Az}$ 1. sz. KK. (közismert és népszerü nevén Tiszti Kórház) 1980ban ünnepelte megalakulásának 30 éves évfordulóját (1980. június 25. 70/1980. MN HF pcs. [20]).

$\mathrm{Az}$ egészségügyi szakember állomány a központi tagozatban egészen páratlan és kiváló volt. Szakterületükön nemcsak a MN-ben, hanem országosan, egyesek európai, illetve nemzetközi mércével mérve is kiemelkedő személyiségek voltak. Ezt példázta az MN EÜSZF 4/1980-as számú intézkedése (1980. 01. 16.), amelyben a Magyar Néphadsereg Orvosi Tudományos 
Tanács (MN OTT) kiegészítéséről rendelkezett az 1979 évben bekövetkezett személyi változások miatt. A terjedelmessége ellenére is érdemes a teljesség igényével felsorolni e Tanács tagjait, hisz az egyszerü olvasónak is sokat mondóak a többségében ismert nevek.

\section{ELNÖK:}

Prof. Dr. Vámos László o. vőrgy., címzetes egyetemi tanár, az orvostudományok doktora

\section{Helyettesek:}

Dr. Hideg János o. ezds.

Dr. Horváth István o. ezds., a hadtudományok kandidátusa

Titkár: Dr. Giacinto Miklós o. alez.

Titkárhelyettes: Dr. Birkás János o. alez.

TAGOK:

Prof. Dr. Bernát Iván nyá. o. ezds., egyetemi tanár, az orvostudományok doktora

Prof. Dr. Bíró György o. ezds., egyetemi tanár, az orvostudományok doktora

Prof. Dr. Fiam Béla nyá. o. ezds., címzetes egyetemi tanár, az orvostudományok kandidátusa

Prof. Dr. Gyarmati László gy. alez., egyetemi tanár, a kémiai tudományok kandidátusa

Dr. Kurucz Tibor gy. alez., a hadtudományok kandidátusa

Prof. Dr. Magyar István o. ezds., címzetes egyetemi tanár, az orvostudományok kandidátusa

Prof. Dr. Manninger Jenö o. vőrgy., egyetemi tanár, az orvostudományok kandidátusa

Nagy Dénes gy. alez.

Dr. Sugár Béla o. szds.

Dr. Varga István o. alez.

Dr. Wittek László o. ezds.

Prof. Dr. Zoltán János címzetes egyetemi tanár, az orvostudományok doktora
ÖSSZESÍTVE 4 fő címzetes, 4 fő rendes egyetemi tanár, 4 fó az orvostudományok doktora, 2 fó hadtudományok, 3 fö az orvostudományok, 1 fö pedig a kémiai tudományok kandidátusa volt.

Bátran állíthatjuk, hogy az orvosi tudományos munka, a kutatási területek vezetése megnyugtató kezekben volt [21].

Az MN EÜSZF 1980. február 29-én adta ki az 1981. január 01-től hatályba lépő 12/1980. számú intézkedését, a csapatrendelök egészségügyi anyagi normájáról és a 31/1980. számú utasítását az ö.áeü.o szervezési müködési szabályairól 1980. május 30-án [21].

A Honvédelmi Miniszter a 0253/1980. számú parancsával 1980. április 1-jétől Dr. Giacinto Miklós orvos alezredest, az MN KKK pk. tudományos helyettesét, a MNOTT titkárát nevezte ki az MN Katona-orvosi Kutató Központ parancsnokává [21]. Személyében a hazai aneszteziológiai és intenzív terápia kiemelkedő alakját tisztelhettük, akinek óriási szerepe volt a háborús újraélesztési rendszer elméleti, gyakorlati és eszközös, egymásra épülő rendszerének kialakításában, a csapattagozattól az intézeti tagozatig (RE-I, RE-II, ARE).

A szolgálat az alapellátás kiszélesítését is felvállalta, amikor 1980 júniusában az MN EÜSZF 34/1980. számú intézkedésével elrendelte az „MN kórházaiban általános szakorvosi rendelés létesitését" az MN nyugállományú tagjai (hivatásos és kinevezett polgári), a katona-egészségügyi ellátásra jogosult hozzátartozók gyógyító-megelöző alapellátásának fejlesztése érdekében. A rendeletet az MN kórházainak rendelőintézeteiben „általános szakorvosi rendelés" szerint kellett szervezni és müködtetni napi 6 órában, általános szakorvos vezetésével. $\mathrm{Az}$ alapellátást azon nem nyugállományú katona-egészségügyi ellátásra jogosult 
hozzátartozók részére is biztosítani kellett, akik orvosi beutaló nélkül jelentkeztek. A rendelők feladata volt az általános gondozás is. Ez óriási terhelést jelentett a kórházaknak, főleg a fővárost illetően. A lakótelepek közelsége, a csapatorvos nélküli kis alakulatok ontották ezeket a betegeket. A rendkívül rövid határidő arra utalt - június 24-én adták ki az intézkedést július 1-jei működési idővel -, hogy már egy valamilyen formában régen müködő rendszer legalizálása történt [21].

Jelentős szakmai előrelépést - a fejezet elején már említett magas szintű képesség megjelenését - jelentett az $M N$ 1. sz. KK. Echo-cardiographias laboratórium müködésének beindítása az év közepén (MN.EÜSZF 40/1980. sz. intézkedés).

A laboratórium a szív-keringési rendszer megbetegedéseinek minél korábbi felismerése, a szívgyógyászati diagnosztika fejlesztése érdekében létesült. Feladatait természetesen MN szinten teljesítette, így hétfőn és szerdán az $\mathrm{MN}$ KKK, kedden és csütörtökön az 1 . sz. KK, továbbá a vidéki kórházakból, valamint az MN ROVKI-ból elöjegyzett betegeket fogadta. Pénteken tudományos célú vizsgálatokat végeztek. A laboratóriumot a két fövárosi katonai kórház föbelgyógyászai felügyelték (Dr. Németh István o. ezds. MN KKK, Dr. Hajdú Béla o. ezds. 1.sz KK) [21].

A vizsgálati módszert Magyarországon Dr. Lengyel Mária 1972-ben vezette be az Országos Kardiológiai Intézetben. (Dr. Lengyel Mária: Echo-cardiographia medicine, 1978. 8. old.)

Már ekkor is feszítő gond volt a megfelelő intézeti háttér hiánya, a hoszszabb intézeti ellátást - elsősorban ápolást-igénylő krónikus megbetegedésben szenvedők nagy száma miatt. Megjegy- zem, ekkor még az ellátás gazdaságossági hatékonysága nem volt vezető szempont. Ezt a helyzetet próbálta valamelyest enyhíteni az MN EÜSZF 46/1980. számú intézkedésével, amely a „hosszabb ápolást igénylö betegeknek az MN Szanatóriumaiban történő beutalásáról" rendelkezett. Ez a teher föleg a kórházak aktív, azon belül is a bel-típusú osztályait nyomta, amelynek enyhítésére átmeneti megoldásnak gondolták az MN Szanatóriumaiban a hosszabb ápolást igénylö betegek ellátására szervezett részleget. Ezen részlegekbe csak az MN KKK és az MN 1. sz. KK utalhatott be kizárólag a „86/1978. (HK.1.) HM-EÜMIN számú együttes utasítás 3.\$-ában meghatározott katona-egészségügyi ellátásra jogosult" beteget. Az MN 4. Szanatórium (Hévíz) „C” osztályán 14, az MN 5. Szanatórium (Balatonfüred) „A” és „B” osztályain 6-6 ágyon történt a feladat ellátása, funkcionális részlegként müködtetve. Javaslatot a beutalásra az osztályvezető főorvosok tehettek. Döntéshozatal a kórházparancsnok vezetésével müködtetett bizottság - föbelgyógyász, fösebész (MN 1. sz. KK-ban sebészet ov. főorvos) - feladata volt. Ha a beteg állapota a szanatórium részlegében súlyosra fordult, akkor visszaküldték a beutaló kórháznak, életveszélyben a legközelebbi polgári kórházba. Az 1980 augusztusában aláírt intézkedés 1980. október 1-jén lépett hatályba [21].

1980 augusztusa a fegyelem és az etikai helyzet szigoritása érdekében kiadott intézkedések jegyében telt el, gondolva az előző évben történtekre, és a tanulságok közreadására. Augusztus 5-én a 47/1980. MN EÜSZF-i intézkedés „ $A z M N$ gyógyító intézeteiben folyó gyógyitó- megelöző tevékenység szakmai ellenörzéséröl" szólt, de emellett a bevezetőben egyértelmüsítette, hogy a címen túlmenően az ellenőrzések 
célja az volt, hogy a „szervezési és etikai követelmények az érvényben lévő rendelkezéssel és elvárások szerint érvényesüljenek". Az ellenőrzés alapvető feladatát képezte az, hogy az intézeti gyógyító-megelőző ellátás szakmai színvonaláról, szervezeti feltételeinek alakulásáról, a munka rendjéről, a betegellátással kapcsolatos etikai követelmények megvalósulásáról, a FÜV eljárások helyzetéről, illetve a gyógyító-megelőző tevékenységet szabályozó rendelkezések hatályosulásáról tárgyilagos információk álljanak rendelkezésre. $\mathrm{Az}$ ellenőrzések segítségével megfelelő időben fel kellett ismerni, illetve meg kellett elözni a rendelkezésekben foglalt követelményektől eltérő gyakorlatot, illetve magatartást. Osztályokig lemenően szabályozta a betegellátással kapcsolatos ellenőrzési feladatokat, és külön pontokban (7. és 8. pont) foglalkozott a nagyon érzékeny, és a bajt okozó felülvizsgálati tevékenységgel, annak kritikus pontjaival [21].

Augusztus 6-án az MN EÜSZF kiadta a 48/1980-as számú intézkedést „az MN egészségügyi szolgálata etikai helyzetének megszilárditására" vonatkozóan, amely alapvetően az Egészségügyről szóló 1972. évi II. törvény, valamint annak az MN-ben történő végrehajtását szabályozó 23/1974. számú HM utasításon alapult. Az intézkedésről - elsősorban a hadseregen belüli orvos-beteg kapcsolatról - már a bevezetőben idéztem. Az intézkedést áthatotta a felelősség szellemisége abban a tekintetben, hogy az elvárt elkötelezettséghez az egészségügy szakmai és gazdasági célkitűzései hozzájárulhattak az etikai helyzet javulásához. Külön szólt az egészségügyi káderek kiválasztásáról, a képzés, továbbképzés, tudatformálás fontosságáról, az információ tartásáról a beteg és orvos kapcsolatában, külön kiemelve a hálapénz elfogad- hatatlanságát. A betegfelvétel területén csak a sorállományú betegekkel kapcsolatos csapatorvosi és kórházi kötelezettséget említette [21].

A 80 -as évek elején a népesedéspolitika kiemelt társadalmi feladatául a családés növédelmi ellátást tüzte ki. Az MN-ben ennek külön hangsúlyt adott az elsősorban továbbszolgáló állományba felvételre került nők arányának a növekedése. Ezt a tendenciát elég ellentmondásosan kezelték, még a szolgálaton belül is, hisz míg a csapattagozatban speciális katonai és szakmai képzést szerveztek a számukra 1982-ben, addig a 80-as évek közepén aZ akkori MN EÜSZF limitálta a női orvostanhallgató ösztöndíjasok számát.

Az MN EÜSZF az 54/1980-as számú intézkedéssel „A katona-egészségügyi ellátásra jogosultak család-és növédelmi ellátását" szabályozta csapatszinten és az intézeti tagozatban, a fö felelősként kijelölt 1. számú KK Szülészeti és Nőgyógyászati osztályát érintően [21]. Ez mind a két szinten egy komplex egészségnevelési feladatot jelentett, amely a központi tagozatban kiegészült a feltételek biztosításával is. Az egészségnevelés és a gondozás ekkor vonult be az egészségügyi szolgálat amúgy sem kevés feladatai közé. Elméleti kérdései is ekkor újulnak meg és kerülnek megismerésre. A tanácsadó szerv müködését 1981. januárjától kezdte meg [21]. Személyes tapasztalatom szerint ez a tanácsadó inkább csak a központi tagozatban müködött, hisz a csapattagozatban, a távoli helyőrségekből nem vállalták az 1. sz. KK-ba való felutazgatásokat, és inkább a kisebb helyőrségeket vagy a mellettük lévő kórházakat és terhes gondozást keresték fel, illetve részesítették elönyben. A csapattagozatban gyakorlatilag ez a feladat nem fordult elö. Az egészségnevelést azonban rendkívülien fontos kérdésként kezelték.. A ún. „nem fertőző 
betegségek epidemiológiája” ebben az évtizedben került a társadalom és még inkább az egészségügy látókörébe. A szürővizsgálatok és felmérések, a lakosság, ezen belül az MN állományának egészségi állapota figyelmeztetett az egészséges életmód megismerésére, annak fontosságára. Az MN EÜSZF 55/1980. számú intézkedése, amely „Az MN Egészségügyi Szolgálatfőnökség Egészségvédelmi és Egészségnevelési Tanácsának létrehozásáról" szólt, igencsak frappánsan fogalmazta meg a célt és a rendeltetést. „Társadalmunk és az MN jelen fejlődési szakaszában jogos igényként jelentkezik a személyi állomány egészségének fokozott védelme, egészség károsodásoktól való megóvása, illetve egészségi állapotának tervszerü javítása. Figyelembe véve, hogy az MN személyi állománya körében az egészségtelen életmód (túlzott alkoholfogyasztás, helytelen táplálkozási szokások és esetenként következményes kóros elhízás, a dohányosok magas aránya), és a nem megfelelö testkultúra elterjedése észlelhető, továbbá lassú az előrehaladásunk az egészséges életmódra nevelés területén; a betegségek megelözése, a szolgálat- és munkaképesség fenntartása érdekében fel kell lépni a helytelen táplálkozási szokások, az elhízás, a túlzott alkoholfogyasztás ellen, a dohányzás visszaszorításáért, $s$ mindezek érdekében fejleszteni kell a személyi állomány egészséges életmódra nevelését, fizikai és pszichikai állóképességét. Végezni kell az MN-en belül az anya-, csecsemő-, és gyermekvédelmi népesedés- és nőpolitikai érdekek egészségügyi szempontból történő képviseletét, továbbá elősegíteni az egészségügyi rehabilitációs tevékenységet" [21].

Az MN kiemelt feladata 1980-ban a jubileumi díszszemle volt, amelyben az egészségügyi szolgálat sok szinten és nagy létszámmal vett részt. A szűrővizsgálatok, a védőoltások, ezred és zászlóalj szintü segélyhelyek működtetése, a folyamatos és állandó közegészségügyijárványügyi ellenőrzések, a szabad ágyak biztosítása, a begyakorlások állandó helyszíni támogatása, komoly szervezési munkát, nagy igénybevételt jelentett mind a központi, mind a csapattagozat számára [21].

Ebben az évben miniszterhelyettesi szinten (043/1980. MN HF sz. intézkedés) szabályozták a vezetóállomány (magasparancsnoki) tagjainak szanatóriumi beutalását és az $\mathrm{MN}$ gyógyító intézeteiben történő elhelyezését [21]. A magasparancsnoki beosztásokat még 1975-ben szabályozták (020/1975. HM sz. belső utasítás 3/a. pontja). Ez többek között tartalmazza, hogy a beutalásokat csak az 1. sz. KK állíthatja ki, a hozzátartozó is beutalható és miután a feltételek adottak voltak, a kiemelt elhelyezést (magasabb parancsnoki betegszoba) is biztosítani kellett [21].

A központi tagozatból egy intézménynél az MN 5. sz. Szanatóriumánál került sor MN HF-i szemlére, melyet személyesen Stadler János vezérörnagy, az MN HF vezetett [21].

Az egyre növekvő tábori technikai eszköztár kiszolgálását a 08/1980. MN HF-i intézkedés tartalmazta, amelyből a kor igen modernnek számító egészségügyi berendezéseit ismerhetjük meg $[6,21]$.

Ezek az alábbiak voltak:

a) Hazai gyártmányú eszközök

- Tábori sterilizáló és vízdesztilláló készülék (AKVA)

- Kötöző gépkocsi

- Mozgó fogászati rendelő felépítményben

- Tábori mütő, konténerjellegü felépítményben 
- Bakteriológiai, Szerológiai Laboratórium (BSL) felépítményben

- Higiénés-entomológiai Laboratórium (HEL) felépítményben

- Mozgó laboratórium (ML) felépítményben

- Toxikológiai Laboratórium (TL) felépítményben

- Kórbonctani Laboratóriumi (KBL) felépítményben

- Vírus Laboratórium (VL) felépítményben

- Vivárium (VIV) felépítményben

- Egészségvédelmi-Radiometriai Laboratórium (ERAL) felépítményben

- Infúziós Laboratórium felépítményben

- Demineralizáló-Sterilizáló Berendezés (DSB) felépítményben

- Mozgó Egészségügyi Javító Műhely (felépítményben, mechanikai)

- Mozgó Egészségügyi Javító Mühely (felépítményben, elektronikai)

- Medirönt-41 típusú tábori röntgen készülék

b) Külföldi gyártmányú eszközök

- Jéggyártó berendezés (JGB)

- Vérszállító gépkocsi (VSZ gk.)

- Tábori Fürdető-Fertőtlenítő Berendezés (PDP-2)

- Tábori Fürdető-Fertőtlenítő Berendezés (DDA-2)

- Tábori Fürdető-Fertőtlenítő Berendezés (DDA-66) [6].

Év végén hatálytalanitottak egy sor, 1959 és 1960 között kiadott szabályzatot, illetve szakmai müködési utasítást. Így az Eü/52 Eü. biztosítás TÖPFE alkalmazásának körülményei között, a Mozgó Sebészeti Kórház (MSK), Mozgó Fertőző Kórház (MFK), Osztályozó-Kiürítő Állomás (OKÁ) és az Önálló Egészségügyi Osztag (ö.eü.o.) szakmai utasítását, az Eü/47 a Harckocsik víz-alatti átkelésének egész- ségügyi biztosítása és az Eü/14. A Szárazföldi Csapatok háborús egészségügyi biztosítása című kiadványokat.

Az 1981-es esztendő kiemelkedő feladata az V. ötéves terv lezárása és a VI. ötéves terv feladatainak és célkitüzéseinek a meghatározása volt. Az V. ötéves terv egy sor tényt és hasznosítható adatokat tartalmazott, melyekből néhányat érdemes felsorolni [7]. Az alapokat itt is az elöljárók e tárgyban kiadott intézkedései, direktívái jelentették (0085 HM direktíva, 0086 MN HF-i intézkedés és feladatterv, valamint az MSZMP Néphadseregi Bizottsága 1980. októberi állásfoglalása). Jelentős eredményekről számolt be az V. ötéves tervidőszak, de az értékelés előrebocsátotta, „hogy a szükségletek és igények nagyobbak voltak (erőteljesebbek), mint a feltételek javulása".

Megkezdődött a 300 ágyas győri kórház építése. A csapatrendelők 35\%-át felújították. A fejlődés a megbetegedési, illetve az egészségi állapotot jellemző mutatókban is tetten érhetö, így:

- a gyakorlatilag egészségesek aránya 60,7\%-ról 65,2\%-ra nőtt,

- a kórházi gyógykezelést igénylö, illetve a megelőző gyógyüdülésre szorulók aránya 22,5\%-ról 17,3\%-ra csökkent,

- a behívhatók aránya 76,2\%-ról 89,9\%-ra nőtt,

- a korlátozásokkal alkalmatlanok aránya 5,7\% lett 1979-ben (Az adatok az 1965-ös értékekhez viszonyítottak.)

A dokumentum kiemelte, hogy az orvosok 43\%-a (országosan 16,4\%) a szakdolgozók 13\%-a (országosan 6,1\%) tagja a pártnak.

$\mathrm{Az}$ egészségügyi tiszthelyettesek létszámaránya nem változott, továbbra is kedvezőtlen az öt év alatt végzett 157 fö ellenére. 1975 és 1980 között 117 fiatal csa- 
patorvossal bővült a csapategészségügyi szolgálat, a feltöltöttség elérte a $85 \%$-ot. $20 \%$ közülük kórházi beosztásba került. Változatlanul gondot jelentett a fogorvosi ellátottság. 10000 före csak az 1,6-1,7 fogorvos jutott az MN-ben, szemben az országos 2,8-as átlaggal. A katonaorvosi utánpótlás jelentős gondokkal küzdött. Az ösztöndíjasok 40\%-a szerződést bontott, a többiek 3-4 éves csapatszolgálat után leszereltek. 1976-80 között 24 fö. A békeidőszaki feladatokat a VI. ötéves tervben az alábbiakban, mint a „Béke egészségügyi ellátás fejlesztési program” határozták meg.

„A társadalomban felerősödött egészségtelen életmód és a nem megfelelö testkultúra terjedése a hadsereg körében is észlelhető (túlzott alkoholfogyasztás, helytelen táplálkozás - 46 éven felüliek 8\%-a elhízott -, dohányzás). Ennek érdekében az egészségnevelést kiemelt feladatként kell kezelni. Nagyon fontos az alap- és intézeti tagozat közötti integráció. Korszerüsíteni szükséges a kórház és rendelőintézeti struktúrát, annak felszerelését. Az alapellátás területén az első helyőrségi csapatrendelő és az összevont laktanya egészségügyi ellátás továbbfejlesztése kiemelt feladat. A csapattagozat fejlesztésénél az alapellátás hozzáférhetőségének megszilárdítására, az általános szakorvosi szint fokozatos és gyorsabb ütemü kibontakoztatására van szükség. A harckocsi ezred rendelöit kézi táska diagnosztikai eszközzel (KTD) szereljék fel. Minden EKG tanfolyamot végzett orvost a csapatszinten is EKG készülékkel kell ellátni. A fogászati gépek korszerüsítésével javítsák a fogászati ellátás technikai feltételeit. Az intézeti tagozat fejlesztése során az intézmények fejlesztésével egybekötött rekonstrukcióval, illetve belső szervezeti átcsoportosításokkal a honvédelem egészségügyi feladatok figyelembe vételével, szakmánként differenciáltan fejlesztést vagy fenntartást kell megvalósítani (1981. június 1.)" [7].

Az V. ötéves tervet a következő központi egészségügyi intézetek és seregtest szintü hadrendi elemek fejezték be és vágtak bele a VI. ötéves terv fentiekben felsorolt, igencsak nagy volumenü, sok szakmai területet érintő feladataiba:

- MN Egészségügyi Szolgálatfönökség (MN EÜSZF-ség Budapest)

- MN KKK Budapest

- MN 1.sz. KK Budapest

- MN 2.sz. KK Kecskemét

- MN 3.sz. KK Pécs

- MN 4.sz. Szanatórium (Hévíz)

- MN 5.sz. Szanatórium (Balatonfüred)

- MN 6.sz. Katonai Kórház Előkészítő Törzs Parancsnokság (Győr)

- MN Egészségügyi Anyagellátó Központ (MN EÜAK)

- MN ROVKI Kecskemét

- MN Közegészségügyi-Járványügyi Állomás (MN KÖJÁL Budapest)

- MN KOKK Budapest

- MN Felülvizsgálati Bizottság (MN FÜV Budapest)

- Hátországvédelmi Alakulatok Parancsnoksága $M$. Törzs

- Mozgó Kórházcsoport (MKCS) M. Törzs (Budapest)

- Eü. Tartalék M. Törzs (ET Budapest)

- 5. Hds.Egészségügyi Szolgálatfönökség (Székesfehérvár)

- 3. Hdt. Egészségügyi Szolgálatfőnökség (Cegléd)

- 1. Ho.lé.hds.Egészségügyi Szolgálatfönökség (Budapest)

- Hátországvédelmi Alakulatok Egészségügyi Szolgálatfönökség (Budapest)

- CSRP Egészségügyi Szolgálatfőnökség (Börgönd) [6-7]. 
A VI. ötéves terv feladatain túl egy sor szakmai feladat is jelentkezett. Még az előző évben, 1980 november 10-14. között, az 1.sz. KK-nál végrehajtott felügyeleti szemlén megállapították, hogy a kórház sebészeti beteganyaga hátrányosan befolyásolta a szakorvosi képzést, ezért 1981. februárjában az MN EÜSZF 8/1981. sz. intézkedésében elrendelte az MN KKK akut beteganyagának a beutalási területéről való betegátirányítást az MN 1. sz. KK sebészetére, valamint ugyancsak az 1.sz. KK Fül-orr-gége osztály ágyainak kihasználatlansága miatt az üres ágyakra mozgásszervi betegek elhelyezését. Gyakorlatilag ekkor született meg az első fekvőbetegeket ellátó Reumatológiai osztály a katona egészségügyben. Ugyanebben az intézkedésben utasították az 1.sz. KK-t a már előző évnél említett „Családi- és Nővédelmi Tanács” létesítéséről szóló beszámolóra [25].

Ujj, IV. sz. Belgyógyászati Osztály kezdte meg müködését az MN KKK-ban 1981 novemberében, amelynek érdekében a I. Bel osztály 90 ágyát felezték meg, így két 45 ágyas belgyógyászati osztály létesült, természetesen eltérő szakmai profillal (39/1981. MN EÜSZF-i int.) [25].

Az év folyamán kiderült, hogy a sebészeti osztályok akut mütéteinek száma az igényjogosult és katona betegeket figyelembe véve kevés. Ezért az MN EÜSZF 44/1981. sz. intézkedésében elrendelte $a$ katonai kórházak sebészeti osztályain az akut általános sebészeti mütéti számok növelését, ami azt jelentette, hogy a traumatológiához hasonlóan engedélyezték, hogy a katonai kórházak általános sebészeti osztályára, hetente egyszer, a kórház parancsnoka által meghatározott napon akut, általános sebészeti mütétet igénylö katona-egészségügyi ellátásra nem jogosult (területi) - beteget vehessenek fel. Az ilyen ágyak számát a kórház parancsnok határozta meg az MN Fősebész javaslatának figyelembe vételével [25].

A kórházak élelmezési ellátására is kiterjedt a figyelem. Az MN HF 26/1981. sz. intézkedésében az MN kórházainak és szanatóriumainak a betegélelmezés helyzetének komplex vizsgálatát rendelte el, a betegélelmezés hiányosságának feltárása és az ellátás javítása érdekében. A vizsgálatoknak ki kellett terjednie az élelmezéstechnológiára, feltételekre, eszközökre, kiszolgálásra, beszerzésre és a dietetikára. Az 1981. március 3-án elrendelt vizsgálatot szeptember 30 -ig kellett befejezni a tapasztalatok és javaslatok jelentésével [26].

Talán a pályántartás irányába ható elgondolásnak nevezhető az $\mathrm{MN} \mathrm{HF}$ 90/1981. sz. intézkedése, „Az MN állományába tartozó orvosok és fogorvosok nyilvántartásba vételéről." Ez egy 1960ban kiadott szabályozást szüntetett meg. A különböző mellék- és másodállás vállalásokhoz az orvosok és fogorvosok részéről ebben az időszakban előfeltétel volt az „országos orvosi nyilvántartásában” való szereplés. Az intézkedés ezt engedélyezte. Ez alapján a hivatásos katonaorvos az orvosok országos nyilvántartásába való felvételét közvetlenül kérhette, ha az MN-en kívül orvosi, illetőleg fogorvosi oklevélhez kötött munkaviszony létesítésére - szolgálati viszonyon kívüli munkavállalásra vonatkozó rendelkezések szerint - érvényes engedélylyel rendelkezett [26].

Gyakorlatilag ez egy illegális helyzetet legalizált, hisz sok kis helyőrségben számos csapatorvos vett részt az akkor körzeti orvosnak nevezett polgári alapellátást biztosító munkakörben. Több, 1974-ben végzett csapatorvos leszerelésének pont ez a nyilvántartási hiány volt az oka (Rétság, Lenti, Mezőtúr, Orosháza, Kiskunfélegyháza, Nagyatád). 
A központi tagozatban az év folyamán 1981. június 11-töl 22-ig egészségügyi módszertani bemutató foglalkozás került végrehajtásra, „Tábori kórház égett sérültek szakosított szakorvosi ellátásnak lehetőségei tábori kórházakban" címmel [25].

Egy fontos szabályzat, az EÜ/18-as is megjelent, amely az „Utasitás a katonai egészségügyi alkalmassági vizsgálatokra (I. rész)" címet viselte. Ugyanakkor változás történt a szakorvosi szürőcsoport parancsnoki beosztásában is. Dr. Béres László o. alezredest, Dr. Klucsár Tivadar o. alezredes váltotta fel [25].

Ebben az évben 1981 júniusában a központi tagozat egy intézete, az MN 4. Szanatórium (Hévíz) került "felügyeleti szemlére", amelyen az MN HF 43/1982. sz. parancsa alapján „Kiváloo” eredményt ért el [27].

Az évet egy igen fontos dokumentum zárta le, miszerint az MN HF 121/1981. sz. parancs alapján Dr. Vámos László orvos vezérőrnagyot az MN Egészségügyi Szolgálat fönökét a Honvédelmi Miniszter a 01040/1981. sz. parancsával 1982. január 1-jei hatállyal az MN Egészségügyi Szolgálat Főnökség állományából nyugállományba helyzete. Utódjául $D r$. Németh István orvos vezérőrnagyot nevezték ki 1982. január 1-jétől. Ö az MN Főbelgyógyásza volt, nagyon gazdag csapattapasztalattal. Kinevezését mind a központi, mind a csapattagozat egészségügyi szolgálata kedvezően és örömmel fogadta. Tevékenységét azonban nem lehet értékelni, mivel 1982 márciusában máig sem ismert és tudott okok miatt az irodájában szolgálati fegyverével öngyilkosságot követett el.

Helyette megbízással Dr. Horváth István orvos ezredes - az MN Egészségügyi Szolgálatfönök-helyettes - egy év időtartamra megbízott MN EÜSZF-ként látta el a beosztást.
Az 1982-es év két fontos intézkedés hatályba helyezésével kezdődött, melyek jelentős többletmunkával jártak, föleg a csapattagozatban, viszont igen sok hasznos információhoz lehetett az alapellátás területéről jutni.

$\mathrm{Az}$ első ilyen intézkedés az $\mathrm{MN}$ EÜSZF-ség és REVA szolgálatfönökének közös intézkedése, amely többéves kísérleti alkalmazás után került bevezetésre. Ez a személyi állomány megbetegedéseit érintö egységes számitógépes rendszer kialakitása volt. „Csapatgyengélkedő Naplót", amelyben a megjelent betegek betegségével kapcsolatos összes írott anyag szerepelt, félévenként kellett zárni, és a létszámadatokat is figyelembe vevő és igazodó kódolt jelentést kellett szeptember, illetőleg március 05-ig minden korcsoportra, állománykategóriára vonatkozóan felterjeszteni [27].

A másik intézkedés a (37/1982. MN EÜSZF) már az előzőleg említett 1980. július 01-től a kórházakban müködő általános szakorvosi rendelők müködését és feladatkörét módosította. Uj feladatként határozták meg:

- a nyugállományúak alapgondozását;

- a nem igényjogosultak ellátás utáni további alapellátásra utalását;

- a hivatásos és sorállomány szürését;

- a polgári alkalmazottak alkalmassági vizsgálatát;

- a gépjárművezetői alkalmasság elbírálását;

- és a védőoltások végrehajtását.

Tulajdonképpen a későbbi - foglalkozás egészségügyi rendelők - alapjait rakták le ekkor, kiegészítve a nyugdíjasok gondozásával [22, 27].

Ugyancsak ehhez a speciális szakterülethez tartozik, illetve sorolható az MN HF 5/1982. sz. intézkedése, a munkaköri alkalmasság orvosi vizsgálatáról és 
véleményezéséról. Ez a katonai szervezet egészségügyi szolgálatfönökének a munkaköri alkalmasság elbírálásában végzendő feladatait határozta meg. Az „Alkalmas”, „Nem Alkalmas” és az „Ideiglenes Alkalmas" minősítéseket vizsgálat alapján kellett meghoznia. A munkakörök veszélyességének eldöntésével a Katonai KÖJÁL/KÖJÁL Decentrum állásfoglalása volt a mérvadó. $A z$ intézkedés részletesen szabályozta az egyes munkaköri területre vonatkozó elöírt vizsgálatokat, a mérgező anyagokat (károsító tényezőket), veszélyes munkaköröket és az elvégzendő vizsgálatok gyakoriságát [27].

$\mathrm{Az}$ elmúlt évi 1. sz. KK sebészeti típusú osztályainak hatékonyabb müködése érdekében meghozott döntések alapján 1982. május 1-jével megkezdte a müködését a Reumatológiai és Fizikoterápiás Osztály - a Fül-orr-gégészeti osztály ágyainak terhére -8 ágyon (21/1982. EÜSZF int.) [27].

A VI. ötéves terv az alapellátás területén kiemelt jelentőségü feladatként kezelte a Helyörségi Csapatrendelö (HCSR, Nagykanizsa), illetve az összevont csapatrendelők müködésének beinditását. A helyőrségi csapatrendelő egyesítette a csapatrendelők és a kórházi rendelök feladatait. 1982. július 22-én adta ki az MN EÜSZF a 42/1982. sz. intézkedését, amely a létesítésről és szervezésről szóló 00133/90/1981. MN VKF Szervezési Csoportfönökség intézkedésére hivatkozva szabályozta az intézmény szakmai müködését. Meghatározta, hogy a kétszintủ ellátást (alap- és szakellátás) hogyan egészíti ki a helyőrség egészségügyi kiképzési, egészségnevelési feladataival és a külön díjazással járó ügyeleti szolgálattal. A felügyelet kicsit bonyolultra sikeredett. A szakmai felügyeletet a 3 . sz. KK látta el. A müködéssel és a szervezéssel kapcsolatos feladatokat az MN EÜSZFség Gyógyító osztálya és az 5 . Hadsereg egészségügyi szolgálata végezte a kísérleti szakaszban, melynek célja a müködési, illetve gyakorlati tapasztalat megszerzése volt.

A HCSR szakmai elöljáró fönöke a 8. gl.ho. egészségügyi szolgálatfönöke (Zalaegerszeg) volt és önálló alegységként a 14. gl. e.(Nagykanizsa) állománytáblájában szerepelt orvos parancsnok vezetésével [27].

Az év folyamán három jelentősebb az egészségügyi állományt érintö - gyakorlat került végrehajtásra. Az egyik a már említett [15] április 15-24. között végrehajtott „M” parancsnoki és összekovácsolási gyakorlat, melynek tapasztalatai a későbbi szervezési változásokba kerültek beépítésre [27].

A másik a június 21-26. között végrehajtott "DUNA-82" hadgyakorlat egy magyar (11. hk.ho), egy csehszlovák (13. hk.ho CSN) és egy szovjet gépesített lövész hadosztály ( 245 gl.ho SZU) részvételével.

A májusi egészségügyi hadijátékot épphogy befejezte az 5 . hadsereg egészségügyi szolgálata, amikor az alegységeiből erre a gyakorlatra a 91. (Nagykanizsa) és a 195. ö. eü. o.-k(Vác) jelölték ki 250 fö tartalékos állományú egészségügyi szakemberrel. Az értékelés alapján „Az egészségügyi osztagok jól begyakorolták a részlegek telepítését, a sérültek hátraszállítását és ellátást" [28].

A harmadik pedig a június 16-25. között egészségügyi módszertani bemutató gyakorlat levezetése volt, ahol sebészeti profilu tábori kórház került telepítésre, gyakoroltatásra és bemutatásra. (39/1982. EÜSZF-i pcs.) [27].

A VI. ötéves terv egyik fö feladata a kiürítés fejlesztése volt. Ennek érdekében - elsősorban a csapattagozatban beszerzésre kerültek a LUAZ-967 sebesültkihordó gépkocsik a ZHS-k kiürítö 
képességének minőségi és mennyiségi javítására [8].

A Zaporozsec motorral ellátott 2 fó fekvő sérült kiürítésére alkalmas, úszni és csörlözni tudó eszköz a különböző bemutatók és gyakorlatok fö látványossága lett. Hibáira és sebezhetőségére a szovjet-afganisztáni háború során derült fény. Nem lehetett azonban azonnal igénybe venni, miután a kiképzők kiképzését befejezték az MN EÜSZF és az MN Páncélos és Gépjármü-technikai Szolgálat fönöke „tartósan betároltatta” a jármüveket és harckészültség esetén „hátrahagyott" eszközként kezelte. (08/1982. MN EÜSZF és MN PCGJMÜ Technikai Főnök, 1982.12.09.) [8].

A későbbi beruházásokra, illetve fejlesztésekre elörevetítendően - egy intézkedés megjegyzéséből, amely eredendően ellátás, utalás módosításáról szólt - derült fény. Nevezetesen „Az 1. sz. KK tervezett rekonstrukciója szükségessé teszi az MN KEÜAR területe egy részének igénybe vételét". Ezt a feladatot már egy megbízott vagy új parancsnok hajtja végre, mivel a központ parancsnokát Megyeri György gy. alezredest az Egészségügyi Minisztériumba vezényelték, magasabb beosztásba. Feladatát megbízással Seres Károly gy. alezredes (Pk.h.), áruforgalmi osztályvezetö vette át (54/1982., 561982. EÜSZF-i pcs.) (MN EÜSZF 60/1982.) [27].

Az év végén jelent meg az új felülvizsgálati rendszer bevezetését meghatározó intézkedés, amely elsősorban szervezési feladatokat tartalmazott. Alkalmazását és végrehajtását 1983. január 1-jével kellett megkezdeni. Intézményenként, kórházankét Elsőfokú $F \ddot{U} V$ Bizottságot kellett müködtetni. Az MN 2. fokú FÜV bizottsága Budapesten müködött 3 fövel, esetenként a vidéki intézményekben a helyszínen is (kiszál- lással) (71/1982. EÜSZF-i intézkedés) [27].

Még egy elöremutató személyügyi parancsot érdemes ebből az évből megemlíteni. A HM Államtitkár (ÁT) 039. sz. parancsában 1982. augusztus 1-jei hatállyal kinevezte Dr. Ónodi István alezredest az MN 6. sz. Katonai Kórház [KK. (Győr)] parancsnokává [8].

Sajnálatos módon ez az év bővelkedett nagyon szomorú eseményekkel, aktív és vezető beosztású katonaorvosok elhalálozásával:

Dr. Sugár Béla o. ezredes, az MN KKK parancsnoka július 3-án hunyt el, akinek beosztását megbízással, 1982. augusztus 1-től egy évig Dr. Altmann István o. ezredes látta el (01273. HM pcs.) [29].

Dr. Kovács Ottó o. alezredes, az MN 4. sz. Szanatórium parancsnokhelyettese március 21-én halt meg.

Dr. Piros Kálmán o. alezredes a Traumatológiai osztály intenzív részlegének megalakítója, a Jemeni Népi Demokratikus Köztársaság magyar Kórházában elsőként szolgáló és Etiópiában is egészségügyi feladatokat ellátó katonaorvos május 22-én hunyt el. (43/1982., 32/1982 MN EÜSZF-i pcs.) [27].

Az 1983-as esztendő egy jelentős szakmai döntés meghozatalával kezdődött. Január 19-én a 9/1983. MH EÜSZF-i intézkedés rendelkezett a $M N$ KKK Mứvese Állomásának müködéséről úgy, hogy az állomásnak szeptember 1-jétől működőképesnek kellett lennie [29].

Három fontos honvédelmi miniszteri, valamint VKF-i parancs, illetve döntés alapján szervezési feladatok kerültek meghatározásra, amelyet szolgálatfőnöki intézkedések szabályoztak és váltottak aprópénzre. A miniszter döntött, hogy az MN 1. sz. KK-t és annak fóépületét az egyes szakmai funkciók korszerüsítése és 
üzembiztonsága érdekében 1984. II. negyedévében felújitásra tervezzék. Ennek érdekében 1983. október 01-ig az MN KKK VII. épületét ki kell üríteni. A Fertőző Osztályt a Fővárosi László Fertőző Kórházba, a Tüdőgyógyászati Osztályt - az ambulancia kivételével - az Országos Korányi TBC és Pulmonológiai Intézetbe helyezték át, ami a jövőt tekintve elörevetítette a két osztály lassú halálát, megszünését is $(49 / 1983$. MN EÜSZF int.) [29].

Szintén a honvédelmi miniszter rendelte el még 1982-ben (90/1980. HM pcs.) a Magyar Néphadsereg 1945-töl 1980-ig eltelt időszaka történetének teljes körü, átfogó kutatását, tapasztalatainak írásba foglalását „nyílt” jelleggel. A végrehajtásra 1983-ban intézkedett az MN EÜSZF. Célként határozta meg, hogy a kutatás során tárják fel az egészségügyi biztosítás törvényszerüségeit, hatékonysága fokozásának további lehetőségeit. Segítse a had- és történelemtudományt, katonai, társadalmi-gazdasági megítélésben. A feldolgozás során megbízható és hiteles képet, hasznosítható ismereteket kellett nyújtani a szolgálat számára. A teljesítési határidőt 1984. március 30-ában határozták meg. Konzulensként az MN Főgyógyszerészét, Dr. Kurucz Tibor gy. alezredest jelölték ki (80/1983. MN EÜSZF intézkedés) [29].

Az MN VKF a 0068/19/1982. sz. intézkedésében még szerepelt a Hadtáp Kiképző Központ „orvoskiképző” századának kiválása és diszlokálása. Az orvoskiképzö században a sororvosok, fogorvosok és gyógyszerészek kiképzése 1983. augusztus 1-jétől az MN 3. sz. KK (Pécs) részeként folytatódott. A kiképzés ideje 12 hónap volt. Ebből 3 hónap bázisképzés (1 hónap újoncképzés, 2 hónap szakmai képzés) volt. Ezt követte a 9 hónapos csapatgyakorlat. A kiképzés évente négy turnusban, csoportonként 100 fö részvételével zajlott. A kiképző század a pécsi tüzérezred laktanyájában került elhelyezésre, a sororvosok által „Bagolyvár”-nak elnevezett körletben. Az MN 3. sz. KK parancsnokának 1983. július 11-ére kellett a kiképzési programot elkészítenie. Az első oktatási és kiképzési turnust augusztusban kezdték meg. A kiképzés minőségi színvonala és hatékonysága érdekében tábori belgyógyászati, tábori sebészeti és egészségügyi anyagellátási szakkabinetet alakítottak ki. A csapatsegélyhelyek működési feltételei megismeréséhez egy gyakorló tábori ezredsegélyhelyet (ESH) biztosítottak. A kiképző század parancsnokává 1983. augusztus 1-jével az MN 3. sz. KK állományából Dr. Ferencz Lajos o. századost nevezték ki [17].

$\mathrm{Az}$ egészségnevelési munka fontosságát már többször említettem, de az egészségügyi szolgálat konkrét munkájához - szekunder prevenció, gondozás szükséges adatok nem álltak rendelkezésre. A gondozáshoz, a rizikófaktorok megismeréséhez az egész Néphadsereg állománya szürővizsgálati rendszerének átalakitására volt szükség. Utoljára 1971ben szabályozták ezeket a vizsgálatokat. „A Magyar Néphadsereg tagjainak egészségi okból történő szolgálat alóli felmentéséről, és szűrővizsgálatáról, valamint gyógyüdültetéséről" szóló 18/1983. sz. HM utasítást az MN EÜSZF-e a 40/1983. sz. intézkedésében igen részletesen szabályozta. Ez alapján kötelezték az egységparancsnokot, illetve a vele azonos, vagy ennél magasabb beosztású vezető állományt az évenkénti, az I. félévben végrehajtandó szürővizsgálatra. Sajnos az intézkedés nem tartalmazta a kockázati tényezők feltárását, melynek fontosságát Dr. Ónodi István o. alezredes által megírt kandidátusi értekezés is leírta, de az általa közreadott ötéves egészségi állapot fel- 
mérés igazolta fontosságát, így az 1987ben bevezetett „személyi szűrővizsgálati adatlap" már tartalmazta a kockázati tényezőket. A szürővizsgálatokat az $\mathrm{MN}$ 1. sz. KK végezte nagy hozzáértéssel és rendkívüli szervezettséggel. A részvételt szigorúan ellenőrizték. A szanatóriumi kezelést és gyógyüdültetést a 45/1983. MN HF intézkedés szabályozta. Balatonkenese nyáron, Mátraháza egész évben, Buják pedig a jogosultakat fogadta [29].

$\mathrm{Az}$ év folyamán három nagyszabású hadgyakorlatra került sor. Januárt az 5 . hadsereg által a szovje déli hadseregcsoporttal közösen vezetett és végrehajtott „DUNA-83” téli hadosztály gyakorlat nyitotta meg, amely az egészségügyi szolgálat számára sok munkával és felelősséggel zárult, miután súlyos rendkívüli események terhelték. A „0" pont közelében egy repeszszilánktól egy fö, a szovjet együttmüködő repülők találattévesztése következtében a marcali tüzérezred táborába csapódó lövedékektől négy fö sérült meg. A legtragikusabb esemény január 21-én 22.00 órakor történt meg, amikor a később megkezdett rakodás és rosszul végrehajtott szerelvény összekapcsolás miatt a személyi állományt szállító vagonok elgurultak, és egy másik vonattal ütköztek Herend térségében. Ennek következtében az MN 60. müszaki dandár 100. önálló műszaki zászlóalj állományából (Szeged) 5 fö meghalt, 9 fö súlyos, 29 fö könnyebb sérülést szenvedett [28].

A nyár folyamán két gyakorlat került levezetésre. A „KUNSÁG-83” 1983. június 2-16. között a 7. gépesített lövészhadosztály (gl.ho. Kiskunfélegyháza) Miniszteri Szemléjének zárógyakorlata volt, míg a másik „BAZALT-83” nevü gyakorlaton az előzővel közel egy időben, június 6-15. között, amelyen a 11. hk. ho. (Tata) vett részt. A két gyakorlaton több alakulat - köztük a hadseregközvetlen 194. ö.eü.o. (Kiskunfélegyháza) - teljes „M” állománnyal vett részt. A két gyakorlaton összesen 14000 fö, 180 löveg, aknavető, $3 \mathrm{db}$ indító állvány, 2800 gépjármü, $210 \mathrm{db}$ harckocsi, $210 \mathrm{db}$ PSZH, és BMP páncélozott szállító harcjármü, $6 \mathrm{db}$ L-29 repülő és $15 \mathrm{db}$ helikopter képezte a harcértéket. A 7. gl.ho. Miniszteri Szemléjének jelentésében az egészségügyi szolgálatról az alábbiak hangoztak el: „Az egészségügyi szolgálat jó színvonalú gyógyító tevékenysége biztosította a személyi állomány egészségének megörzését. Javult csapatsegélyhelyeinek ellátottsága, felszereltsége, állaga. A hivatásos, továbbszolgáló személyi állomány $65,5 \%$ a gyakorlatilag egészséges, $12,5 \%$-a csapatorvosi, 7,8\%-a ambuláns szakorvosi, 2,8\%-a kórházi kezelésre szorul, FÜV elé állítandó 1,57\%." A jelentés megemlíti azt is, hogy a vizsgált időszakban 16 tiszt és 40 tiszthelyettes mondott le szolgálati viszonyáról. A közöttük lévő orvos tisztek - ismereteim szerint 4 fö, Kiskunfélegyházáról 2 fö, Mezőtúr és Kalocsa 1-1 fö - okként azt írták kérelmükben, hogy „gyógyító tevékenységet akarok folytatni”. Ahogy az említésre került, a gyakorlaton a hadseregközvetlen alakulatokból részt vett a 194. ö.eü. osztagot - az 5. hds. 002061/1983. értékelő anyagában így minősítették": 70 fő imitált sérült ellátásával és kiürítésével jó szinten begyakorolták a sebesültek ellátását. Eredményes volt a gyógyító, közegészségügyi és járványügyi munka. (értékelés 31. oldal). A 7. gl.ho. 58. eü. zászlóalja (eü.z) „mivel 5 fővel vett részt a gyakorlaton, nem került értékelésre”. „A 194. eü. osztag tevékenységét »jónak " értékelem". (értékelés 54. oldal) [11].

A MÁTRA-III szervezési feladattal az „M” feladatok szervezése, irányítása, ellenőrzése és végrehajtása egy új hadrendi elem felelősségi körébe, illetve szervezeti alárendeltségébe került [31]. Az 
MN EÜSZF 0017/1983. sz. intézkedésében szabályozta ennek az új alakulatnak a Magyar Néphadsereg Hátországi Egészségügyi Alakulatainak Parancsnoksága (MN HEAP) jog- és hatáskörét. A hadrendbe lépés időpontja 1983. augusztus 1. volt. Gyakorlatilag az MN eü. szolgálatának valamennyi harckészültségi és mozgósítási feladatát a béke és háborús anyagellátást, ezek ellenőrzését az alakulat jogkörébe utalták [17].

Létrehozásának indokául az alábbiakat nevezték meg:

A Hátországi Egészségügyi Alakulatok Parancsnoksága (a továbbiakban: HEAP) létrehozásának kettős célja volt. Egyrészt szükségessé vált egy olyan apparátus, amely az állandó harckészültség időszakában - az MN EÜSZF-ség elvi irányítása mellett - összefogja és irányítja, illetve végzi a háborús feladatokra való felkészülést, a mozgósítás időbeni végrehajtását, az egészségügyi intézetek egészségügyi anyagokkal és egészségügyi technikai eszközökkel való ellátását.

A másik fó célkitüzés az volt, hogy háború esetén - az egészségügyi anyagi és egészségügyi technikai ellátás mellett - az MN Egészségügyiszolgálata rendelkezzen egy olyan tervező-szervező, irányító törzzsel, amely képes a hadmüveleti területen keletkező sérültek hátraszállítását a tábori kórházakból irányítani, és ezen sérülteket elosztani a hátországi kórházakba. E feladatokon túlmenően biztosítani kellett a hátországban tevékenykedő csapatok sérültjeinek kórházi ellátását is.

E konkrét tevékenység-rendszeren kívül igen lényeges volt megteremteni az állami egészségügyiszolgálattal való szoros együttmüködés szervezeti feltételeit. Ez úgy valósult meg, hogy a HEAP szervezetében létrejött 19 megyei és 1 fóvárosi katona-egészségügyi összekötő csoport, valamint az Egészségügyi
Minisztérium vezetési pontján települö Operatív Csoport [36].

Az MN hadtápfőnöke (MN HTPF) Szórádi Zoltán vezérőrnagy az 1984. január 10-én megtartott HM KT ülésen azt jelentette, hogy a „MÁTRA-III” szervezési feladattal összefüggésben korszerüsítésre került, illetve újonnan megalakult hadtáp szervezeti elemek beálltak [30].

$\mathrm{Az}$ irányítási, alárendeltség, anyagellátás és harckészültségi feladatok ellátásán túl a legfontosabb szervezeti öszszetétel és megnevezés változás az volt, hogy a kórházbázisok helyett egészségügyi dandárok alakultak úgy, hogy gyakorlatilag csak a megnevezés változott a megalakító Béke szervezet összetételében néhány „M” szervezet létszámának 1-10 fö közötti növelése, illetve csökkenése mellett. Így az 1. sz. kórházbázisból az 1. sz. eü. dandár (1. sz. eü.dd.) lett és az MN KKK, a 2. sz. kórházbázisból 2. sz. eü.dd. alakult és a 3. sz. KK. (Pécs), míg a 3. sz. kórházbázis neve 3. sz. eü.dd-ra változott, és a 2 . sz. KK (Kecskemét) alakult meg. A dandárok belső szakmai felépítése is közel azonos volt. A dandárok szervezetébe 10-10 TTSK, 5-5 TTBK, 2-2 TFK, 3-3 Könnyüsérült Kórház (KSK), 2-2 Osztályozó-Kiürítő Állomás (OKÁ), 1-1 Járvány-egészségügyi Osztag (JEO), 1-1 Szakorvosi Megerősítő Zászlóalj (SZMZ), 1-1 Sebesültszállító Század (sgk. szd) tartozott. Az 1. sz. dandár 2 ö.eü.o. és 1 á.eü.o., míg a 2 . és 3. egészségügyi dd. csak 1-1 ö.eü.o.-al rendelkezett. A tábori kórházakon kívüli szervezetek (eü.o., JEO., á.eüo.) az előző szervezet, a tábori hadtápfőnökség egyéb szervei közül kerültek átemelésre. Változatlanul szerepelt az új szervezeti rendben is az „Egyesitett Fegyveres Erők (EFE) közvetlen alárendeltségébe átadandó egészségügyi tartalék." Ez $10 \mathrm{db}$ tábori sebészeti (TSK), 2 db tábori belgyógyászati (TBK), $2 \mathrm{db}$ TFK, $2 \mathrm{db}$ 
KSK és 1 OKÁ-ból, összesen 17 intézetből és 1797 főből állt.

Az MN HEAP parancsnokának közvetlen alárendeltségébe tartozott:

- MNMNKORI 1984-től(Kaszópuszta, Somogyszob)

- MN KEÜR

- $6 \mathrm{db}$ ö.eü.o.

- 1 db á.eü.o. (83. sz.)

- $1 \mathrm{db}$ EJO (105. sz.)

- 1 db OKÁ (248. sz.)

- 1 db sgk.szd. (326. sz.)

- $18 \mathrm{db}$ sebesültszállító vonat (SV) (1-16, 252, 207. sz.)

- Mozgó kórházcsoport (MKCS), mely az 1. sz. KK. bázisán alakult meg az alábbi alakulatokkal:
- 1 kiszolgáló és ellátó század (kisz.ello. szd.) (65. sz.)

- $1 \mathrm{db}$ (VEA)

- 2 db TTSK (242-245. sz.)

- 2 db TTBK (246-247. sz.)

- $1 \mathrm{db}$ TFK (236. sz.)

- 1 db OKÁ (249. sz.)

- 1 db sgk.szd. (205. sz.)

Az MN HEAP parancsnoksága békében 85, mozgósítás idején 241 fővel látta el feladatait (9).

$\mathrm{Ez}$ a struktúra gyakorlatilag az évtized végéig nem változott. $\mathrm{Az}$ eü.dd.-k és az MN HEAP közvetlen szervek, valamint az MN EÜSZF-ség alárendeltségébe tartozó alakulatok és szervek összesített létszámadatait az alábbi ábrák tartalmazták:

\begin{tabular}{|l|c|c|c|c|c|c|}
\hline Megnevezés & Tiszt & Tts. & Sor & $\begin{array}{c}\text { Katona } \\
\text { össz. }\end{array}$ & Polgári & Mindössz. \\
\hline Béke & 12 & 4 & 35 & 51 & 27 & 78 \\
\hline „M"-ben & 737 & 922 & 2831 & 4490 & - & 4490 \\
\hline
\end{tabular}

1. ábra. 1. sz. eü.dd. létszámadatai

(Készitette a szerző, az MN rendszeresített és meglévő személyi állomány 1981-1982-1984-1986-ig alapján HL:472d/729 öe.)

\begin{tabular}{|l|c|c|c|c|c|c|}
\hline Megnevezés & Tiszt & Tts. & Sor & $\begin{array}{c}\text { Katona } \\
\text { össz. }\end{array}$ & Polgári & Mindössz. \\
\hline Béke & 10 & 6 & 30 & 46 & 20 & 66 \\
\hline „M"-ben & 706 & 878 & 2740 & 4324 & - & 4324 \\
\hline
\end{tabular}

2. ábra. 2. sz. eü.dd. létszámadatai

(Készítette a szerző, az MN rendszeresített és meglévő személyi állomány 1981-1982-1984-1986-ig alapján HL:472d/729 öe.)

\begin{tabular}{|l|c|c|c|c|c|c|}
\hline Megnevezés & Tiszt & Tts. & Sor & $\begin{array}{c}\text { Katona } \\
\text { össz. }\end{array}$ & Polgári & Mindössz. \\
\hline Béke & 9 & 2 & 23 & 34 & 16 & 50 \\
\hline „M"-ben & 706 & 878 & 2740 & 4324 & - & 4324 \\
\hline
\end{tabular}

3. ábra. 3. sz. eü.dd. létszámadatai

(Készítette a szerző, az MN rendszeresített és meglévő személyi állomány 1981-1982-1984-1986-ig alapján HL:472d/729 öe.) 


\begin{tabular}{|l|c|c|c|c|c|c|}
\hline Megnevezés & Tiszt & Tts. & Sor & $\begin{array}{c}\text { Katona } \\
\text { össz. }\end{array}$ & Polgári & Mindössz. \\
\hline Béke & 65 & 4 & 35 & 104 & 192 & 296 \\
\hline „M”-ben & 1087 & 694 & 2796 & 4577 & 3444 & 8021 \\
\hline
\end{tabular}

4. ábra. MH HEAP parancsnokának alárendelt alakulatok összesített létszámadatai

(Készítette a szerzö, az MN rendszeresített és meglévő személyi állomány 1981-1982-1984-1986-ig alapján HL:472d/729 öe.)

\begin{tabular}{|l|c|c|c|c|c|c|}
\hline Megnevezés & Tiszt & Tts. & Sor & $\begin{array}{c}\text { Katona } \\
\text { össz. }\end{array}$ & Polgári & Mindössz. \\
\hline Béke & 457 & 22 & 228 & 707 & 2903 & 3610 \\
\hline „M”-ben & 3557 & 3754 & 12181 & 19492 & 3444 & 22936 \\
\hline
\end{tabular}

5.ábra.MNEÜSZFalárendeltségébe tartozóállomány (alakulatok)összesitettlétszámadatai

(Készitette a szerző, az MN rendszeresitett és meglévő személyi állomány 1981-1982-1984-1986-ig alapján HL:472d/729 öe.)

A szervezési változások és egyéb okok miatt is az év személyügyi változások tekintetében nagyon izgalmasra sikeredett. A szolgálatfönöki, az MN KKK, az MN 1. sz. KK, és MN HEAP parancsnoki, két főszakorvosi, illetve a szolgálatfőnökség osztályvezetöi beosztásaiban történtek jelentős változások. Az 1982ben a szolgálatfönöki beosztással megbízott Dr. Horváth István o. ezredes helyett 1983. augusztus 1-jei hatállyal Dr. Hideg János o. ezredest, MN Repülö föszakorvosát (később 1984-től vezérörnagy) nevezték ki főnökké [5].

Dr. Hideg János 1933. január 25-én született a Tolna megyei Kalaznón. Budapesten a Ciszterci Rend, majd Bencés Gimnáziumban végezte középiskolai tanulmányait, majd 1951-ben érettségizett. 1951-ben a Pécsi Orvostudományi Egyetemre jelentkezett, ahová felvették, de miután katonának is jelentkezett, így azonnal beiskolázták - akarata ellenére - az Egészségügyi Tiszti Iskolába az Orvostudományi Egyetem helyett. 1951. október 24-én lett katona. Az Egészségügyi Tiszti Iskolát 1 év alatt elvégezte és a Nyíregyházi Huszár Hadosztályhoz alhadnagyi rendfokozatban anyagi tisztnek nevezték ki. Érdekes módon az akkori hadosztályvezető orvos Dr. Németh István o. főhadnagy a későbbiekben tragikusan elhunyt MN egészségügyi szolgálatfönök volt. 1953-ban három főnek engedélyezték az orvostudományi egyetemre való visszatérést, akik közé ő is tartozott. Az orvostudományi egyetemet 1959-ben végezte el. Egyetemi évei alatt folyamatosan a kórélettani intézet tudományos diákkör tagja volt. 1957-ben lett honvédségi ösztöndíjas. Az egyetem elvégzése után Egerbe került ezred vezető orvosnak. Abban az időben 54 üres orvosi beosztás volt. 1960-ban a Gyáli úti Repülö-alkalmassági Vizsgáló Állomásra egyik elődjének, Dr. Vámos Lászlónak a helyére került. Állatkísérleteket végzett és részt vett a kecskeméti barokamra tervezésében, majd le is költözött Kecskemétre, ahol 1970ig maradt. 1970-ben az Országos Légierő Parancsnokság (OLP) vezető orvosa lett. 1967-68 között orosz nyelvi előkészítőn, majd 1968-69 között a leningrádi KIROV Katonaorvosi Akadémián felső orvos vezetői képzésben vett részt. 1972ben kettévált az OLP: Honi Légvédelmi Parancsnokságra és Légvédelmi Repülö Főnökségre. A repülőorvosi intézet átke- 
rült az MN EÜSZF-ség alárendeltségébe, és így az MN Repülő Főszakorvosa lett 1983-ig, míg az MN EÜSZF-i beosztásba ki nem nevezték. 1978 és 1980 között - a program vezetőjeként - részt vett az első magyar ürhajós kiválasztásában. Kandidátusi és nagydoktori értekezését az ürhajós válogatás fiziológiai paramétereinek méréséből, a vizsgálati rendszerek elméleti és gyakorlati tapasztalatiból írta.

A szolgálatfönöki kinevezés mellett, elhalálozás, tartalékállományba helyezés, nyugdíjas, illetve szervezési változások miatt az alábbi fontos beosztásokban történt még váltás, kinevezés vagy megbízás:

Az MN KKK parancsnoka Dr. Sugár Béla o. ezredes az előző évben elhalálozott. A beosztást megbízással ellátó $D r$. Altmann István o. ezredes helyett a Honvédelmi Miniszter Dr. Birkás János o. alezredest (később ezredes, majd vezérőrnagy) nevezte ki 1983. augusztus 1-jei hatállyal [17, 29]. Az MN 1. sz. KK parancsnokát Dr. Simon Pál o. ezredest a Honvédelmi Miniszter 0770. sz. parancsával, kérelmére, nyugállományba helyezte és helyére kinevezte Dr. Sultész József o. ezredest 1983. augusztus 1-jével [17].

A már említett szervezeti változással létrejött MN HEAP parancsnokának szeptember 1-jei hatállyal az államtitkár Dr. Törő István orvos alezredest nevezte ki [17]. Szintén szeptember 1-jétől nyugállományba helyezték a 0731 . HM sz. paranccsal Dr. Bíró György orvos ezredest, az MN Főepidemiológusát. Beosztását megbízással a HM 01375. parancsa szerint Dr. Kádár Pál orvos ezredest látta el [17]. Az egészségügyi szolgálatfönöknek kinevezett Dr. Hideg János orvos ezredes előző, repülő főszakorvosi beosztását szintén megbízással a 051. sz. HM ÁT parancsával 1983. december 1-jétől Dr. Bognár László orvos alezredes látta el 1984. november 1-ig [17]. Az MN KKK parancsnokának kinevezett Dr. Birkás János alezredes helyett az EÜSZF-ség Szervezési és Kiképzési osztályvezetőjének Dr. Villányi Ferenc orvos alezredest nevezték ki 1983. december 1-jei hatálylyal [17].

Két új parancsnok gyógyító helyettes is kinevezésre került: Dr. Vohlner György orvos alezredes az MN 1. sz. KK-ba, Dr. Sedivi László o. százados pedig az MN 4. sz. Szanatóriumába szeptember 1-jei hatállyal [17].

$\mathrm{Az}$ 1984-es esztendő bővelkedett a különböző infrastrukturális beruházásokban, fejlesztésekben és az intézményrendszer számának növekedésében. Különösen fontos ezt hangsúlyozni azért, miután a polgári egészségügyhöz viszonyítva ez jelentős minőségi elörelépést jelentett. $\mathrm{Az}$ előző évben megtervezett és előkészített MN 1. sz. KK felújításának megkezdéséről az 1984. január 10-i HM KT ülésen döntöttek véglegesen, miszerint „ $A z M N$ Tiszti kórház február 9-ével a rendelöintézet kivételével bezár. A felújitás helyzetéről decemberben és 1985 júniusában kell jelenteni" [30]. A feladat végrehajtására az MN HTPF és az MN EÜSZF is intézkedett. Ezek alapján az első negyedévben megkezdődő rekonstrukció érdekében „a Gyermekgyógyászat, a Semmelweis Orvostudományi Egyetem (SOTE) Gyermekklinikájára, a Szülészeti-Nőgyógyászati Osztály és szakrendelés az 1. sz. Női Klinikára, a többi részleget - az általános szakorvosi Rendelö kivételével - és a parancsnokságot az MN KK-ba kell kitelepiteni”. „A teljes kitelepitést 1984. február 29-ig be kell fejezni." (001/1984 MN HF intézkedés) [32].

A felújítás várható befejezésének időpontját 1986. első felében határozták meg. Az MN 1. sz. KK személyi állományának megoszlását az egyes intézetek között a felújítás időszakában a 6 . ábra szemlélteti. 


\begin{tabular}{|l|c|c|c|c|c|}
\hline Megnevezés & MN KKK & $\begin{array}{c}\text { 1.sz. Nöi } \\
\text { Klinika }\end{array}$ & $\begin{array}{c}\text { 1. sz. Gyer- } \\
\text { mekklinika }\end{array}$ & 1. sz. KK & Összesen \\
\hline Orvos & 61 & 9 & 7 & 3 & 80 \\
\hline Szakdolgozó & 88 & 37 & 19 & 2 & 146 \\
\hline Egyéb & 91 & 10 & 3 & 73 & 177 \\
\hline Összesen: & 240 & 56 & 29 & 78 & 403 \\
\hline
\end{tabular}

6. ábra. 1. KK személyi állományának megoszlása a felújitás időszakában (Készitette a szerzö, a 001/1984. MN EÜSZF-i intézkedés alapján)

Az év kiemelkedő eseménye az MN 6. sz. KK, (Győr) rendszerbe állítása volt. Az MN HF 027/1984. sz. intézkedése az MN 6. sz. KK béke és háborús szakfeladatairól, valamint müködésének és gazdasági ellátásnak rendjéről az alábbiak szerint fogalmazta meg ezt a pillanatot. „A Honvédelmi Bizottság (HB) 00502/77. sz. határozatára a Győr-Sopron Megyei Tanács Kórházának fejlesztéséhez kapcsolódva - közös beruházásként - Györ helyörségben 300 ágyas új katonai kórház létesült. Az MN VKF 05/151/1984. sz. szervezési intézkedésével a kórházat, mint az $M N$ 6. sz. KK-t 1984. május 01-jei hatállyal hadrendbe állította..."

Háborús szakfeladatai érdekében „a később meghatározandó helyőrségben polgári kórházra települve - 500 ágyat, ugyanakkor Győr helyőrségben továbbra is gondoskodjon egy 300 ágyas kórházrészleg működtetésérôl", mely feladatokat 1986. január 1-jéig kellett végrehajtani. A kórház a gyógyító szakfeladatait 1984. november 1-jén kezdte meg [32]. Ezeket a feladatokat az MN EÜSZF a 010/1984. sz. intézkedésében határozta meg, az alábbiak szerint:

„3/a. A szakorvosi járóbeteg ellátás, a gondozás, szűrés és szakgondozás céljaira belgyógyászati (két munkahely [mkh]), általános sebészeti ( $1 \mathrm{mkh})$, égés sebészeti (1 mkh), ideg-elme (1 mkh), szemészeti (1 mkh), gégészeti $(1 \mathrm{mkh})$, fogászati ( $2 \mathrm{mkh})$, röntgen ( $1 \mathrm{mkh})$, és labor (1 mkh) szakrendeléseket;

b./ a fekvőbeteg kivizsgálás és kezelés célára belgyógyászati ( 80 ágy), ideg (40 ágy), elme (40 ágy), általános sebészeti (40 ágy), baleseti sebészeti (40 ágy), idegsebészeti (40 ágy), és égési (20 ágy) osztályokat alakítsanak ki.

4....A 3. pontban nem szereplő szakrendeléseken és fekvőbeteg osztályokon (ortopédia, urológia, érsebészet, bőrgyógyászat, nőgyógyászat, gyermekgyógyászat, tüdőgyógyászat, onkológia, művese és egyéb speciális szakrendelések) történő szakellátásokat a megyei kórház szakrendelésein és fekvőbeteg osztályain kell megszervezni.

5. A járó- és fekvőbeteg ellátáshoz szükséges - a megyei kórházban müködő valamennyi - diagnosztikus (rtg-, klinikai-, izotóp-, endoszkópiás-, kardiológiai-, audiológiai-, labor- stb.) kivizsgálásokat és kezeléseket (fizikoterápia, intenzív ellátás, sugárkezelés stb.) a megyei kórházzal együttmüködésben kell biztosítani.”

Az 1. sz. melléklet alapján a

- személyi állomány feltöltését 1984 . július 30-ig.

- az üzembe helyezési szakfeladatokat 1984. augusztus 1-ig

- a kórház müködőképességének az elérését 1985. július 30-ig

- a nővérszálló üzemeltetését 1985. március 31-ig kellett befejezni [32]. 
Részben új intézményként került a rendszerbe a Kaszópusztán létesített „MN Kondicionáló és Regeneráló Intézet”. „M” elrendelése után gyógyító-utókezelő feladatok ellátása volt a feladata, és az MN HEAP közvetlen alárendeltségébe került. A békeidőszaki feladatait - pilóták kondicionálása, a többi nem egészségügyi feladat kivételével - az MN EÜSZF határozta meg. Szakmai felügyeletét az MN ROVKI látta el. Működőképességét 1984. szeptember 1-jén érte el [32].

$\mathrm{Az} 1983$ augusztusában hadrendbe állított MN HEAP működőképességét az év elejére érte el. Emiatt a megalakításakor meghatározott feladatokat (0017/1983. sz. MN EÜSZF intézkedés) kiegészítették [17]. A feladatait a vezető, irányító és ellenőrzési tevékenységének szabályait a 0011/1984. sz. intézkedés az alábbiakban határozta meg

\section{HKSZ, „M” és háborús felkészítés területén:}

1. Vezesse és irányítsa az egészségügyi intézetek HKSZ-„,M” és háború felkészítés területén végzendő munkáját. Negyedévente ellenőriztesse és egyeztesse a HKSZ és „M” terveket...

2. Folyamatosan és tervszerüen ellenőriztesse az „M” eü. anyagi bázisokat, a hadrafoghatóság és a háborús anyagok tárolása, csoportosítása szempontjából.

3. Minden év negyedik negyedévében a tárgyévben végrehajtott összekovácsoló és „M” parancsnoki kiképzések összegzése és a hiányosságok megszüntetése céljából vezessen le egynapos konferenciát az eü.dd.-ok, az MKCSF-ség és az eü. tartalék parancsnokai és „M” törzs parancsnokai részére.

4. Szervezze meg és irányítsa az egészségügyi intézetek sorállományának lebiztosítását, alapkiképzését.
5. ...Gyüjtse, értékelje és összesítse az egészségügyi intézetekről és „M” törzsektől felterjesztett jelentéseket...

\section{Béke és „M” egészségügyi anyagellátás területén:}

6. Az MN EÜSZF által átruházott jogkörben az MN HEAP parancsnoka:

a./ Hajtsa végre a HM közvetlen katonai szervezetek (csapatok, intézetek, kórházak, szanatóriumok) egészségügyi anyagellátásának szakmai irányítását.

b./ Önálló jogi személyként - a meghatározott jog- és hatáskörben - kötelezettséget vállalhat, jogokat szerezhet - (szerződéskötés és felbontás, megrendelés és lemondás, áralku, kötbér igény érvényesítésének kezdése, stb.). Tartson kapcsolatot a népgazdaság termelö, kereskedelmi és szolgáltató szervezeteivel.

d./ Hajtsa végre az állami egészségügyi tartalék ellenőrzését, az $\mathrm{MN}$ EÜSZF-ség irányításával, az MN EÜSZF által elrendelt, valamint a saját éves terve szerinti téma és célellenőrzéseket.

e./ ...jogvitás ügyekben polgári jogi szerveknél biztosítsa a szolgálat képviseletét...

f./ Az MN EÜSZF által jóváhagyott terv és felhatalmazás alapján szakmaigazdasági ellenőrzéseket hajtson végre az önálló gazdálkodást folytató csapatoknál, intézeteknél, egyéb katonai szervezeteknél.

\section{Béke egészségügyi ellátás területén:}

7. Hajtsa végre - a katonai kórházak és szanatóriumok kivételével - a HM közvetlen katonai szervezetek egészségügyi ellátásának szakmai felügyeletét, illetve egészségügyi szolgálatainak szakmai irányítását.

8. A 6/a. pontban jelölt katonai szervezetek szakmai ellenőrzéseit az MN EÜSZF-ség gyógyító osztályával együtt- 
működve szervezze. Az ellenőrzések során működjön együtt az MN KÖJÁL-lal.

9. Fogadja és dolgozza fel a csapategészségügyi szolgálat eü. helyzetjelentéseit, az évi szürővizsgálatokról felterjesztett jelentéseit, valamint a megbetegedési statisztikai jelentéseket; ezek alapján öszszegező, értékelő jelentést terjesszen fel évente október 01-ig az MN EÜSZF-ség gyógyító osztályára.

10. A 6/1982 (HK.5.) MN EÜSZF és MN REVA SZF sz. együttes intézkedésben elrendelt megbetegedési statisztikai jelentés pontos elkészítését és az MN HEAP-nak határidőre történő felterjesztését a jelentésre kötelezett csapategészségügyi szolgálatoktól követelje meg, $s$ a beérkezett jelentéseket a fenti intézkedésnek megfelelően az adatfeldolgozó központnak, illetve az MN REVA intézet által megküldött eredménytáblákat a jelentőknek továbbítsa" [32].

Az MN HEAP hadrendbe állításával az $\mathrm{MN}$ intézeti és csapat háborús egészségügyi biztosítása az alábbiak szerint valósult meg:

„A Magyar Néphadsereg csapatai egészségügyi biztosításának megszervezéséhez a várható feladatok nagyságához igazodó egészségügyi erők és eszközök állnak rendelkezésre. Mindezek alapján tekintsük át azokat az egészségügyi szervezeteket, melyek MN szinten a szakosított ellátás biztosításának szolgálatában állnak.

A Magyar Néphadsereg Egészségügyi Szolgálatfőnökség szakmai irányítása alatt álló, az úgynevezett központhadtáp alárendeltségében levő egészségügyi szervezeteknek két nagy csoportja különíthetö el. Az első csoportba a Központ Hadtáp Elöretolt Lépcsö (KHEL) közvetlen irányítása alá tartozó egészségügyi szervezetek tartoznak, melyek a hadmüveleti területre elvonuló, alapvetően szárazföldi csapatok szakosított szakorvosi ellátását végzik. A KHEL alárendeltségében három egészségügyi dandár öszszesen hatvan gyógyító intézete közel 20000 ágyon biztosít a csapattagozatból beérkező sérültek szakosított szakorvosi ellátásának személyi és tárgyi feltételeit. A három eü. dd. gyógyító intézeteinek zökkenőmentes tevékenységét további, mintegy 10 szervezet (alegység) segíti és hangolja össze. Az egészségügyi dandárok kiemelten fontos szerepét támasztja alá az is, hogy állományukban több mint 1500 orvos tevékenykedik. Az egészségügyi intézetek és szervezetek második csoportjába a központhadtáp hátországi szerveihez tartozók alkotják. Meghatározott harckészültségi fokozat elrendelését követően az addig közvetlenül a Magyar Néphadsereg egészségügyi szolgálatfönökének alárendelt katonakórházak, szanatóriumok és intézetek a $\mathrm{Ma}$ gyar Néphadsereg Hátországi Alakulatok Parancsnokságának utaltságába kerülnek át. A megalakításra kerülő sebesültszállító vonatok más, ugyancsak ebben az időszakban mozgósított szervezetekkel egészíti ki a Magyar Néphadsereg Hátországi, Egészségügyi Alakulatok alárendeltségébe tartozókat.

Közvetlenül a Magyar Néphadsereg egészségügyi szolgálatfönök alárendeltségébe tartozik - tartalékként - a Mozgó Kórházcsoport (MKCS), melynek állományába több tábori gyógyító intézet tartozik, mintegy 2000 ággyal. Az MKCS felhasználására az egészségügyi szolgálatfönök közvetlenül intézkedik, vagyis a hadmüveleti területen és a Magyar Népköztársaság területén egyaránt sor kerülhet alkalmazására.

Természetesen mindenki előtt világos, hogy állandó kórházaink és szana- 
tóriumaink háborús körülmények között megnövelt ágykapacitása a felmerülő igényeknek csupán töredékét képes kielégíteni. A reális szükségletek biztosítására az Egészségügyi Minisztérium - a megállapodások értelmében - további kórházi ágyakat bocsát rendelkezésünkre, melynek egy része katonai kiürítő kórházakban, további része pedig szükség (kiegészítő) kórházakban kerül felállításra.

A központhadtáp tagozat jellemzett két nagy csoportjának nagyságára utal, hogy személyi állományának létszáma meghaladja a 20000 föt és feladataikat mintegy 5000 gépjármü, illetve önjáró technikai eszköz igénybevételével oldják meg.

Szolgálatunk vezetésének felelösségteljes feladata, hogy a haditechnikai fejlesztések (újabb fegyvertípusok megjelenése, korábbiaktól eltérő harceljárások kimunkálása stb.) alapján a várható sérültszámhoz, valamint sérülési típusok ellátásához igazítsa ennek a tagozatnak is az ellátó kapacitását, felszereltségét" [37].

$\mathrm{Az}$ egészségügyi szolgálat vezetése egészségügyi történelmi szempontból is fontos szabályzókat vezetett be, illetve szüntetet meg ebben az évben.

$A$ vércsoport és $R h$ faktor meghatározásával az MN VKF 06/1984. sz. intézkedésében elrendelt új mintájú személyi igazolványokban feltüntették ezeket az adatokat, amely a sorköteles katonától a hivatásos és továbbszolgáló állományig mindenkire vonatkozott. (05/1984. MN EÜSZF int.) [32].

$A z$ MN katonai kórházaiban egyre több külföldi - elsősorban az akkor „harmadik világnak” nevezett országokból, úgy, mint Jemen, Bissau Guinea, Vietnám stb. - állampolgárságú beteget vizsgáltak ki és gyógykezeltek. Ezeknek a betegeknek a magas szintü, közmegelégedést szolgáló kivizsgálását, gyógykezelését és ápolását fontos feladatnak érez- ték és mindenki megelégedésére látták el. Az intézkedés a jelentési rendet szigorította, és követhetőbbé tette a beteg útját és állomásait (27/1984. sz. MN EÜSZF intézkedés) [33].

Az ENSZ Egészségügyi Világszervezetének (WHO) ajánlása alapján 1984. február 1-töl a himlö elleni kötelezö védőoltást (karcolás, skarifikáció) megszüntették, valamint a 19/1974. MN EÜSZF-i utasítás erre vonatkozó 2 . sz. mellékletét hatálytalanították (1/1984. MN EÜSZFintézkedés) [33].

Ebben az évben is kellett kellemetlen szakmai döntéseket hozni. Az MN 3. sz. KK-ban 1983-ban súlyos szakmai hiányosságok fordultak elő, föleg az ún. ügyeleti és hétvégi időszakokban. A feltárás és kivizsgálás után a 28/1984. MN EÜSZF-i intézkedés határozta meg azokat a feladatokat, amelyek a kórházban folyó szakmai tevékenység színvonalának emelése érdekében kellett végrehajtani, úm.:

„• ügyeleti szolgálat szigorítása,

- ügyeleti időben a labor és röntgen vizsgálatok elvégzése,

- orvosi kar és szakdolgozók továbbképzése, különös tekintettel az ügyeleti akut ellátás és szövődmények korai felismerésének kérdéseire,

- az intézet valamennyi orvosa három évenként orvostovábbképző intézeti tanfolyamon való, illetve más szakmai továbbképzéseken való részvétele,

- folyóirat referátumok és referálások kötelezővé tétele,

- kliniko-patológiai értekezlet az 1983ban bekövetkezett események elemzésére,

- ügyeleti rendszer bővítése,

- orvosetikai előadássorozat elrendelése és kötelezővé tétele,

- és minderről a kórházparancsnok elemezze a történteket, vonja le a következtetéseket és jelentsen róla" [33]. 
Az 1983. évben lezajlott szolgálatfőnöki, kórház parancsnoki, főszakorvosi és egyéb beosztásokban bekövetkezett változások egyenes következménye volt a tudományos munkát, szakmai irányok meghatározását és a kutatásokat koordináló és szervező legfőbb tudományos tanács, a Magyar Néphadsereg Orvosi Tudományos Tanács (MN OTT) 1984. július 1-jével történö átalakitása, és mint újdonság, a különböző szakterületek müködtetésére elgondolt ún. szakosztályok létrehozása. Ezek a következők voltak:

- Eü. szervezés és harcászat,

- Belgyógyászat,

- Sebészet,

- Toxikológia,

- Ideg-elmegyógyászat,

- Sugárbiológia,

- Repülőorvostan.

A tagok felsorolásából kiderült, hogy egykét kivételtől eltekintve 1980-hoz képest a Tanács teljesen kicserélődött. Ezzel együtt a tudományos minősítéssel rendelkezők száma is jelentősen csökkent. Az új tagokból csak hatan (Dr. Hideg János, Dr. Horváth István, Dr. Novák János, Dr. Manninger Jenö, Dr. Magyar István, Dr. Birkás János) rendelkeztek tudományos fokozattal, professzori címmel ebben az időszakban.

Az újjáalakult Tanács

ELNÖK:

Dr. Hideg János o. ezds., MN EÜSZF

Helyettesek:

Dr. Horváth István o. ezds. MN EÜSZF H

Dr. Farkas József o. ezds. MN KKK parancsnok tudományos helyettese

Dr. Novák János o. ezds. MN Égés-plasztikai föszakorvos

\section{TitKÁR:}

Dr. Rékai Miklós o. őrgy. NOTT titkár

HeLYetTES:

Dr. Bokor Tamás o. hdgy. NOTT szervező föorvos
TAGOK:

Prof. Dr. Manninger Jenő o. vőrgy. MN fösebész

Dr. Medveczki Pál o. ezds. MN 2. sz. KK pk., majd MN EÜSZF H

Dr. Hajdu Béla o.

ezds. MN főbelgyógyász

Dr. Magyar István o. ezds. MN föideg-elmegyógyász

Dr. Bagi János áo. ezds. MN föállatorvos

Dr. Birkás János o. ezds. MN KKK pk.

Dr. Kádár Pál o. ezds. MN mb. föepidemiológus

Dr. Varga István o. ezds. MN EÜSZF-ség Gyógyító Osztály, osztályvezető

Dr. Gelencsér Ferenc o. alez. MN Labor föszakorvos

Dr. Villányi Ferenc o. alez. MN EÜSZF Szervezési Osztályvezető

Nagy Dénes gy. alez. MN főgyógyszerész Dr. Bognár László o. alez. MN mb. repülő föszakorvos

Dr. Remes Péter o. alez. MN ROVKI pk.

Benkö György gy. alez. tudományos fömunkatárs

Dr. László Imre o. őrgy. MN EÜSZF-ség kiképző föorvos [33].

Az egészségügyi szolgálatot - a háborús feladatokhoz hasonló eljárási és ellátási elvek alapján - a katasztrófák egészségügyi következményeinek felszámolásába is bevonták. A 0070/1984. MN HF intézkedése az MN érintett csapatai és intézetei hadtáp biztositására a Paksi Atomerömüben esetlegesen elöforduló üzemzavar esetében az alábbiakat határozta meg:

„2.A feladatok végrehajtása során keletkező sérülteket és betegeket a csapatok saját járműveikkel az első orvosi ellátás után - az állapotuktól függően -, a dunántúli részen tevékenykedő csapatok, Pécs 3. KK, a Duna-Tisza között tevékenykedők Kecskemét 2. KK-ba adják le. Tömeges sérülések és megbetegedé- 
sek esetén a lakosság mentésére kijelölt egészségügyi osztagok végezzék a sérültek és betegek ellátását és kiürítését. A mentési munkára kijelölt csapatok müködtessenek segélyhelyet, az ehhez szükséges fogyó és nem fogyó egészségügyi anyagokat a "30 napos" készletből vigyék magukkal. A mozgósítás útján megalakuló egészségügyi és járványügyi osztagok teljes egészségügyi anyagi készleteikkel vonuljanak el. A felhasznált készleteket - ha az elrendelt készletek 50\%-ra lecsökkentek - a központi egészségügyi anyagraktárból soron kívül vételezzék." A feladathoz kijelölt erők az egészségügyi szolgálattól: az érintett csapatok segélyhelyei „M” állománnyal, valamint a központi tagozatból a 202. és 218. ö.eüo.; 105.ejo, valamint a 2. és 3. KK [32].

A szárazföldi haderő két hadosztálya is "miniszteri” szemlére került. Az 5. hadsereg 8. gl.ho. (Zalaegerszeg) 59. eü. zászlóalját (Nagykanizsa) Bácsai Lajos őrgy. "M” törzsfőnök vezetésével „jó”-ra, a 3. hadtest 15. gk. lövész hadosztály (Nyíregyháza) 55. eü. zászlóalját (Nyíregyháza) pedig Oravecz András őrgy. „M” törzsfönök irányítása alatt „megfelelö”-re értékelték (001/1984. és 0014/1984. HM pcs.) [34].

Három vezetői beosztásba történt kinevezést érdemes megemlíteni.

Dr. Kovács Máté o. ezredest 1984. március 01-től a HM AT 09. sz. parancsával az MN KKK parancsnokhelyettesévé;

Dr. Király Margit o. alezredest 1984. május 01-től a HM AT 018. sz. parancsával az MN KKK parancsnok gyógyító helyettesévé nevezi ki [32];

Dr. Giacinto Miklós orvos ezredest az MN KOKK parancsnokát a 01467. sz. HM paranccsal nyugállományba helyezték, helyette december 1-jével a beosztás ellátásával Dr. Gelencsér Ferenc orvos alezredest bízták meg (HM AT 067. sz. parancs) [33].

Az 1985-ös év elején Oláh István vezérezredes, honvédelmi miniszter január 25-én megtartott előző év értékelését és az 1985-ös év feladatait tartalmazó feladatszabó vezetői értekezletén elhangzott előadói beszéde előre vetítette, hogy az egészségügyi szolgálatra, mind a háborús feladatokra való felkészülés, mind az intézetek infrastrukturális fejlesztése, müködéseinek beindítása, valamint az egészségnevelés területén jelentős kihívások várnak. Csak néhány kiemelt mondat a beszédből, amely alátámasztotta a fentieket:

„• 1985-ben folytatjuk-befejezzük a VI. ötéves tervet! (19. old.)

- Az alkoholizálás elleni küzdelem is fontos, a parancsnoki példamutatás (12-13. old.)

- Szojuz-84, Duna-84, Pajzs-84 szárazföldi; Gránit-84, Zengő-84, Tigris-8484 honi légvédelmi gyakorlatok jól szolgálták a háborús feladatokra való felkészülést, melyeket 1985-ben a Dráva-85 és Duna-85 szárazföldi, a Gránit-85, Zengő-85 és Sztrelba lövészetet a honi légvédelmi csapatok részvételével fogják végrehajtani.

- A hadtáp gyakorlatokból kiemelkedik az Orion-85 egészségügyi és a Tranzit-85 közlekedési rendszergyakorlat, amelyeken a hátország védelmi alakulatok is részt vesznek (22. old.)."

A beszéd megemlítette az 1984-ben átadott 6. sz. katonai kórházat (Győr), amely „hozzájárult a kórházi ágyak számának növekedéséhez" [38].

$\mathrm{Az}$ értékelő és feladatszabó értekezlet után két héttel, az MN Egészségügyi Szolgálata eddigi történetének egyik legjelentősebb és a későbbiekben is kiemelt 
fontosságú rekonstrukció, illetve fejlesztés elgondolása került előterjesztésre a HM KT elé.

A címe „Elgondolás az MN Központi Katonai Kórház rekonstrukciós fejlesztéséröl" volt. (Nyt.sz.: 096/1985. MN EÜSZF-ség) [39].

Úgy gondolom, hogy az indoklás kivonatos leírása visszaadja a kor hangulatát, a katona-egészségügy helyzetét, kapacitásait, valamint a betegellátás fekvő- és járóbeteg adatait, a polgári egészségüggyel való kapcsolatát. Az ehhez az indokláshoz kapcsolódó 1980-84. közötti, az MN egészségügyi szolgálatának központi tagozata ágystruktúráját, járóés betegforgalmi adatait az 1. sz. melléklet tartalmazza. Az indoklásból az alábbiak emelhetők ki: az „elkövetkezendő évtizedekben is, mint sokprofilú, bővített szakmai lehetöségekkel rendelkező kórháznak alkalmasnak kell lennie a magas szintű gyógyító-, szakmai kiképző-továbbképző, tudományos-kutató és szakirányító feladatok korszerü ellátására. A rekonstruált kórháznak rendelkeznie kell mindazon szakmai profilokkal és diagnosztikus funkciókkal, amelyeket az orvostudomány jelenlegi állása és a reálisan prognosztizálható jövőbeni fejlesztés tendenciái megkívánnak. Ugyanakkor nem mellőzhető a szakmai ellátást és a betegek gazdasági ellátását szolgáló korszerű szállítási, információs technológiák alkalmazása sem".

A fenti alapvető célkitüzések figyelembe vételével, a kórház központi szerepének megfelelően, a katona-egészségügyi ellátásra jogosultak - mintegy 300000 fö - szükségletei indokolták, hogy az akkori szakmai profilok mellett új profilként ér-, kéz-, ortopéd- és szeptikus sebészeti, reumatológiai és mentálhigiénés osztály létesüljön. Az új profilok létesítése mintegy 250 ágyas bővítést je- lentett, amely az intenzív és a krónikus (lábadozó), valamint a központi felvételi osztály fejlesztését is magában foglalta.

A tervezésben alapvető feladatnak tartották, hogy a rekonstrukció során a pavilonrendszert kombinált, azaz tömbösített pavilonrendszer váltsa fel; a szétszórt sebészeti és belgyógyászati profilokat megfelelően csoportosítsák; a nagyszámú osztályos műtők számát jelentősen csökkentsék és új központi mütőblokkot alakítsanak ki.

A rekonstruált kórházban korszerü, a távlati szakmai fejlesztés lehetőségeit is biztosító szak- és üzemviteli technológia alkalmazását tervezték.

A korszerü üzemviteli funkciók mellett biztosítani kellett az MN szintű szakmai képzés és továbbképzés, valamint a tudományos-kutatói munka elhelyezési és eszköz feltételeit annak érdekében, hogy a KKK perspektívájában a Fegyveres Erők és a Fegyveres Testületek országos vezető intézeteként - egyetemi szinten - alkalmas legyen az Országos Orvos-továbbképző Intézet katonaorvosi fakultásaként is müködni. Ezzel hazai és egyben nemzetközi tekintetben több évtizedes szakmai lemaradásunkat pótolni.

Ez év végén befejeződött az MN 1. KK rekonstrukciója. Az 1. KK a Központi Katonai Kórházzal funkcionális egységben vett részt az $M N$ egészségügyi (kórházi fekvő- és szakorvosi járóbeteg) ellátásban.

A rekonstruált $\mathrm{MN} 1$. KK biztosította a zavartalan betegellátást a Központi Katonai Kórház rekonstrukciója alatt, valamint továbbra is ellátta a MN KKK-ra nem tervezett alábbi funkciókat:

- a teljes igényjogosult állomány, ezen belül elsősorban a budapesti helyőrség szülészet-nőgyógyászati, családvédelmi és gyermekgyógyászati kórházi és szakorvosi járóbeteg ellátását; 
- a HM vezető állománya, a magas parancsnoki és a területileg utalt pk.-i állomány rendszeres szakorvosi szürővizsgálatát, gondozó-megelőző ellátását;

- a MN KKK-val egyeztetett módon részt vett Budapest Helyörség és a területileg utalt igényjogosultak szakorvosi járó- és fekvőbeteg ellátásában;

- a MN KKK-val közösen biztosította a munkásmozgalom veteránjai és hozzátartozóik szakorvosi, járó- és fekvőbeteg ellátását.

Az MN 1. KK Sebészeti és Belgyógyászati osztályai a funkcionális egységből adódóan - a MN KKK lehetőségeit is figyelembe véve - szakosodtak. A rekonstrukció idején - a beruházás I. ütemében - az új építmény a KEÜAR területén szanált épületek helyén került megvalósításra. Ebben az időszakban - a KKK meglévő funkcióinak lényeges beszűkítése nélkül - fenntartható volt az üzemelés.

A rekonstrukció előtti helyzethez viszonyítva javulást jelentett az 1 . KK viszszaköltözése és a korábbinál lényegesen kedvezőbb feltételek közötti működése.

A győri MN 6. KK felfutásával lehetőség nyílt elsősorban a sorállományú beteganyag egy részének átcsoportosítására. Az így kialakult helyzet lehetőséget biztosított arra, hogy a kórházi rekonstrukció II. ütemében a meglévő betegosztályokat befogadó épületeket felújításra az építőknek átadják. A II. ütemben elképzelésünk szerint egyes kórházi osztályokat rövidebb-hosszabb időtartamra (a pavilonok rekonstrukciójának idejére) a Fővárosi Tanács intézeteibe helyezzük ki. A II. ütem megkezdéséig ehhez megfelelő idő állt rendelkezésre.

Az elgondolás megemlítette, hogy a MN KKK diagnosztikai és gyógyító esz- közparkjának 21\%-a korszerü, 38\%-a használható, 41\%-a korszerütlen, elavult állapotú" [39].

A honvédelmi miniszter február 11én engedélyezte az anyag HM KT elé való terjesztését. Igen sok kritikával illeti, de engedélyezi, hogy a február 19-i KT ülésen megtárgyalják azt. A kritikák kézenfekvőek, egyszerűek, és logikusak. Érdemes belöle néhányat felsorolni:

„Szerintem egy ilyen nagy vállalkozás a jelenlegi helyzet alaposabb, elemzettebb bemutatását, s a koncepció jobb, szakszerübb megalapozását igényli!

Ezért szóban próbálja meg a két érdekelt (BFF és EÜSZF) pótolni ezt.

Továbbá:

A KT kapjon, lásson egy áttekinthető makettet az ülésen.

Hol, mikor, kik terveznek más szocialista országban tapasztalatot szerezni? (pl. Prága, Belgrád) Kikkel (szakemberek) konzultáltak?

Soványnak látszik ez az indoklás, éppen a kórházi jelleg, követelmények oldaláról. De az épületek állagát sem érzékelteti ez a jelentés eléggé! A helyzet mindkét vonatkozásban tarthatatlan ugyanis!

Miért épp ennyi?

Ez új hadrendi elem?

Ezeket (s más) követelményeket szakszerűbben kellene érzékeltetni.

Én ezt nagyon hosszú időnek tartom!

Elképesztően elhúzódó építkezés lenne! Ez közel 13 év.

$\mathrm{Ez}$ is fontos szempont! De az még fontosabb, hogy mielőbb megfelelő kórházunk legyen."

A KT ülésen elhangzó kiegészítések néhány, az előbb felsorolt, a miniszter által feltett kérdésekre adott válaszok konkréttá tették a számokat és nem utolsó sorban a bekerülési költségeket. Ezek alapján a 977 ágyas kórház 1220 ágyra nő. A fóépületben 478 betegágyat, 
15 mütőt, 2 osztályos műtőt, 3000 adagos élelmezési központot, központi laboratóriumot, betegfelvételi osztályt, központi gyógyszertárt, oktatási központot, Katonai Kutató Központot, vérellátó központot és a proszektúrát terveztek elhelyezni.

A meghagyásra tervezett betegpavilonokban összesen 742 beteget gondoltak elhelyezni.

A rekonstrukció becsült teljes költsége az első árjavaslat alapján 1984. évi árszinten 4,260 millió Ft volt (I. és II. ütem együtt).

A I. ütemre: 1986-1992 között 4,380 millió Ft-ot,

a II. ütemre: 1992-1996 között 1,140 millió Ft-ot terveztek.

A 11 év rekonstrukciós időszakra prognosztizált költség $5,520 \mathrm{mFt}$ volt. $\mathrm{Az}$ I. ütem költségeit figyelembe véve a kritikus összeg a VII. ötéves tervben 3,7 mFt-tal jelentkezett, ugyanakkor 1990ig már több jelentős építési feladat végrehajtásában is döntés született.

Egy harmadik változat is javaslatba került, melynek alapján:

$\mathrm{Az}$ I. ütem 1987. évi kezdéssel és 1994. évi befejezéssel 4,670 mFt-tal, a II. ütem 1994. évi kezdéssel és 1998. évi befejezéssel 1,290 mFt-tal mindösszesen 5,960 mFt-tal szerepelt.

1985. április 12-én a február 19-i KT ülés határozatának a szellemében és az akkor megszabott feladatoknak megfelelően az MN HF és MN Beruházási és Fenntartási Főnökség (BFF) a Honvédelmi Bizottság(HB) elé terjesztette tervezetét, az egyeztetéseket végrehajtotta, és azt a 0129/1985. MN BFF-ség számú anyagában előterjesztette a KT-nak.

A kórház tervezett kapacitásának indoklására - az egyik fontos nyitott kérdésre - a jövő lehetőségeit vázolták fel, miszerint 11 új orvosi profilt létesítenek, és még lehetőséget láttak arra, hogy az ezredforduló után a betegágyak számát 3-400-zal növeljék. Ugyanez vonatkozik a mütőkre és a diagnosztikai részre is.

Az egyeztetéseknél is kapott kritikákat az előterjesztés.

$\mathrm{Az}$ Országos Terv Hivatal (OTH) részletesebb vizsgálatokat kért az építési költségekről. A Pénzügyminisztérium és az Állami Fejlesztési Bank eltéréseket vett észre a műszaki és egészséggazdasági részadatokban. A HB viszont alkalmasnak tartotta az előterjesztést a megvalósításra.

$\mathrm{Az}$ Egészségügyi Minisztérium a szubintenzív ágyak számát 10-zel, a mütők számát 2-vel kérte csökkenteni, továbbá kifogásolta, hogy miért vannak ezek az új épülettömbben. Az Építési és Városfejlesztési Minisztérium kérte, hogy a kivitelezéssel, a „Középület Építő vállalatot" bízzák meg.

A BFF egy másik előterjesztésében (0128/1985. MN BFF) kérte, hogy az MN KKK rekonstrukciót „Nagyberuházássá" minősítsék [39]. Az MN BFF a VII. ötéves terv építési tervének alapelgondolásának előterjesztésében tükröztette az egészségügyi szolgálat infrastrukturális és fejlesztési feladatait, azok nagyságrendjét. „Az egészségügyi ellátás feltételei - terveinket meghaladóan mind képességben, mind színvonalában számottevően javultak."

A kórházrekonstrukcióra 1986-90 között 1,4 mrd Ft-ot javasolt az előterjesztés [39].

Az 1986-os kezdéshez azonban területre van szükség. Az elgondolásnak megfelelően az első kapavágást az $\mathrm{MN}$ KEÜAR Róbert Károly körúti objektumában teszik meg. Ennek érdekében az MNHF intézkedik az MN KEÜAR áttelepitésével kapcsolatos feladatokra még az év végén (068/1985. MN HF sz. intézke- 
dés 1985.okt.08.). A fent említett objektumból az anyagraktárnak 1986. január 20. és február 1. között kellett átköltöznie a Budapest X. kerület, Zách u. 6. szám alatti új elhelyezési körletbe. Az áttelepülés befejezését 1986. március 01-ig határozták meg [42].

Ugyanezen a február végi Katonai Tanácsülésen jelentett az MNHF az $M N$ üdülői kihasználtságáról, és javaslatokat tett annak növelésére. Az elö-utószezoni 75-77\%-os kihasználtság mellett a föszezoni 78\%-os volt, amely az elöző öt évben soha nem mutatott ilyen alacsony szintet. Az előterjesztő okként az ötnapos munkahét bevezetését, a rövidülő nyári szünetet, a háromszor 6 hónapos kiképzést, a gyakorlatok nyári időszakra történő esését jelölte meg. Megjegyzendő: az üdültetési költségek emelkedése is szerepet játszott a kihasználatlanság kialakulásában. A miniszterhelyettes bejelentette, hogy a már előző évben beharangozott $M N$ Kondicionáló és Regeneráló Intézet (MN KORI) tevékenységét 1985. április 15-től tervezi megkezdeni [39]. Az egészségügy szakmai feladatait az MN EÜSZF intézkedése szabályozta (27/1985. MN EÜSZF sz. intézkedés). A csapatrepülő alakulatok hajózó- és repülőcsapatok ejtőernyős állománya kondicionáló sportképzésére, a kórházi kezelést követő utókezelésre szoruló állományról volt szó. Az előzőeket az MN csapatrepülő pk., az utóbbiakat a gyógykezelést végrehajtó kórház gyógyító helyettese volt jogosult beutalni. A gyógyító turnusok időbeosztását az MN EÜSZF-ség gyógyító osztályvezetője határozta meg, a férőhelykeretet az MN 1. KK parancsnok gyógyító helyettese tartotta nyilván. A kondicionálásra, illetve utókezelésre a gyógyító osztály, a repülő fönökség és a ROVKI állományból vezényeltek az MN KORI-ba orvo- sokat. Utókezelésre a következő betegségcsoportba tartozó betegeket lehetett beutalni:

a) Belgyógyászat: pszichoszomatikus betegségek, krónikus légzőszervi betegségek (kivéve az asztmát), beállított hyperthyreosis,

b) Ideggyógyászat: kifáradásos állapotok,

c) Sebészet: általános sebészeti mütétet követő rekonvaleszcencia,

d) Szemészet és Fül-orr-gégészet: mütétek utáni rekonvaleszcencia és a gondozottak [40].

1985. áprilisának végén egy újabb, a jövő szempontjából is fontos jelentés került az MN KT elé. „A csapatorvosi utánpótlás fejlesztésének lehetőségeire, módszereire, az orvostisztek erkölcsi, anyagi megbecsülésének javitására" címü előterjesztés hü képet ad az akkori egészségügy humán erőforrás helyzetéről. (0278/1985. Eü.sz.) [39].

Az előterjesztésnek két oka is lehetett. $\mathrm{Az}$ egyiket vehetjük kötelezőnek, amelyet a bevezetőben írnak le. „A Politikai Bizottság 1982. június 08-i határozata és a végrehajtására készült $\mathrm{HM}$ „Feladatterv" elóírja javaslat kidolgozását a csapatorvosok szükséglet szerinti utánpótlásának módjaira, anyagi ösztönzésük szakmai előmenetelük javítására." Az e tárgyban végrehajtott vizsgálat és a megállapítások, valamint a javaslatok jelentése az egyik ok [40], a másik az 5. hadsereg egészségügyi szolgálat főnökének cikke a "Hadtápbiztositás" címü folyóiratban, amely a csapatorvoslás akkori helyzetéről, állapotáról és eredményességéről ad számot. Ez többek között megemlítette, hogy „A legfontosabb és legtöbb gondot okozó feltétele a csapat-egészségügyi szolgálatnak az orvostiszti feltöltöttség helyzete. 1979-80 óta egy fokozottabb 
kiáramlási és egy alacsonyabb szintű beáramlási tendencia miatt 1984. évre $50 \%$ alá esett a csapatorvosi feltöltöttségi arány seregtestünknél. Ez évben a fenti arány a kiáramlás csökkenésével, a beosztások feltöltésének az elöljáró által biztosított lehetőségén túl, polgári orvosok hivatásos állományba vételével elérte az 55\%-ot. Örvendetes, hogy a kiáramlás okai között nem a szolgálati viszonyról való lemondás a domináló - főleg az utóbbi 2-3 évben - hanem a szakmai továbbképzést és továbblépést biztosító kórházba helyezési kérelmek elutasítása. Emelkedett az orvos tisztek között a nők száma. 41 feltöltött beosztásból 17 az orvosnők száma. Az egészségügyi tiszthelyettesi állomány feltöltöttsége $86 \%$-os, jónak ítélhetö meg" [41].

Az előterjesztés a tapasztalatok összegzésével nyíltan feltárta a kiáramlás okait és a megoldásra is elfogadható javaslatokat adott. Így megismerhettük a képzés lehetőségeit, feltételeit, a leszerelés okait. „A Néphadsereg orvos tiszti utánpótlását közel két évtizede alapvetően a HM ösztöndíj rendszer keretein belül a hazai orvostudományi egyetemeken, valamint az Szovjetunióban folytatott orvosképzéssel biztosítjuk. Az Egészségügyi Minisztériummal történt megállapodás alapján, az orvostudományi egyetemeken az MN részére évente 50 fö HM ösztöndíjas jelentkezett és a felvételi vizsgán megfelelt fiatal beiskolázása biztosított. A Szovjetunióban 1969-1974-ig folyamatos beiskolázással 1976 és 1980 közötti időben 55 fö szerzett orvosi diplomát."

A két képzési rendszer együttes eredményeként a csapatok hivatásos orvosi feltöltöttsége 1976-1980 között jelentős mértékben javult és elérte a $80-85 \%$-ot (az egészségügyi intézeteké a 92-95\%-ot).

1979-től kedvezőtlen változás következett be, melynek eredményeként a csapatorvos feltöltöttség 1985-re 62\%-ra csökkent. Ez seregtestenként különbözö, pl. az 5. HDS-nél 55\% és vannak olyan helyőrségek, ahol valamennyi ht. orvosi hely (pl. Nagyatádon 6) betöltetlen. Ennek egyik oka, hogy a Szovjetunióban az orvosképzés 1980-ban - a leningrádi Kirov Katonaorvos Akadémia férőhely problémái miatt - ideiglenesen megszakadt. Az új szerződés 1983 évtől újból 10 fő beiskolázását tette lehetővé évenként. A másik oka, hogy a hazai egyetemeken megnőtt az ösztöndíj szerződés bontások száma. A tanulók 50-70\%-a bontotta fel szerződését. Ezek közül az alsóbb évfolyamosok főleg tanulmányi elégtelenség, a 4-6. évfolyamosok (18-20 fö) viszont a polgári életben kínálkozó kedvezőbb - kórházi, rendelőintézeti, körzeti és üzemi orvosi állásokba történő - elhelyezkedési lehetőségek miatt távoztak a szolgálatból.

$\mathrm{Az}$ utóbbi 5 évben a csapatorvosok között is felerösödött a leszerelési tendencia. (1979-1984 között 54 fö). A csapatorvosi beosztások 38\%-át sorkatonai szolgálatot töltő, frissen végzett tapasztalatlan orvosokkal voltak kénytelenek betölteni, ami számottevően csökkentette a csapattagozatban az orvosi ellátás színvonalát. Évente 400 orvos került behívásra sorkatonai szolgálatra, akik 12 hónapos tartalékos tiszti kiképzésben részesültek. Közülük 180-200 fö folyamatosan - 9 hónapig - a csapatoknál teljesített szolgálatot. További kedvezőtlen jelenség, hogy az orvosi pálya elnőiesedése a katona-orvosi utánpótlás terén is egyre inkább előtérbe került, $s$ ez bizonyos határon túl rontotta az alapellátás színvonalát. Az 1980-84 között végzett 85 orvos $41,17 \%$-a volt nő, míg ugyanebben az évben 1984. október 1-ig az orvosegyetemeken tanuló 259 hallgató $49,42 \%$-a volt hölgy. 
Országos tapasztalat, hogy a pályakezdő orvosok közvetlenül a végzés után főleg kórházi munkakör elnyerésére pályáznak. Az Egészségügyi Minisztérium és a tanácsi szervek a helyzet ellensúlyozására több intézkedést adtak ki (lakás, másodállás, mellékfoglalkozás, pótlékrendszer), föként a körzeti- és üzemorvosok élet- és munkakörülményei javítására. Ennek hatására 20\%-kal emelkedett ezen orvosi munkakörök feltöltöttsége. A HM ösztöndíjasok is - annak ellenére, hogy a csapatorvosi szolgálatot vállalták - hasonló igényekkel lépnek fel és a szakorvosi képesítés minél gyorsabb megszerzése érdekében az egyetem elvégzése után kórházi beosztást szerettek volna kapni. Ez nem egyezett a Néphadsereg érdekeivel.

Az 5-6 éves csapatszolgálattal rendelkező katonaorvosok többsége viszont már körzeti- és üzemorvosi beosztásba törekedett. Elhatározásukat befolyásolták:

- azok az anyagi lehetőségek, amelyek fizetésen felüli jövedelem többletet biztosítanak,

- a csapatorvos és a körzeti orvos munkája közötti eltérések, a csapatorvos kevesebbet foglalkozik gyógyító munkával, laktanyai elfoglaltságai (értekezlet, törzsfoglalkozás, ellenőrzés, stb.) elvonják az orvosi munkától.

Megoldási javaslatként jelentették, hogy „közbenjárásunkra az Egészségügyi Minisztérium 1984-ben lehetővé tette, hogy a csapatorvosok meghatározott időtartamú csapatszolgálat és kórházi vezénylést követően az eddigi 4 mellett (általános orvostan, közegészségtan-járványtan, repülőorvostan, társadalomorvos tan) 13 féle (üzemorvostan, reumatológia-fizioterápia, belgyógyászat, bőrgyógyászat, neurológia, radiológia, sportorvostan, klinikai laboratóriumi vizsgálatok, pszichiátria) szakorvosi képesítést szerezhessenek csapatszolgálatuk időszakában.

1983-ban ismét beindították a katonaorvos képzést a Szovjetunióban. A korábbi években Leningrádban végzett orvosaink munkájával és helytállásával kapcsolatban pozitív tapasztalatokat szereztek.

A kialakult helyzet szükségessé teszi, hogy a meglévő lehetőségek jobb kihasználásával hatékonyabbá tegyük a HM ösztöndíj rendszeren alapuló katonaorvos utánpótlást, az ösztöndíjasok és csapatorvosok kiáramlásának mérséklését, szakmai fejlődésük elősegítését, élet- és munkakörülményeik javítását" [39].

Egy új szakmai specialitás alapjainak lerakása is megtörtént ebben az évben. Az MN EÜSZF megbízta Dr. Bognár László orvos alezredest - aki ekkor a Tanulmányi Módszertani Osztály vezetője és megbízott repülő főszakorvos - 1985. február 15-vel az MN KKK pszichológiai laboratóriumának szakmai igazgatásával. Egyben feladatul kapta az MN és az MN KKK főideggyógyászokkal együttmüködésben az MN KKK rekonstrukciós tervével összhangban, hogy alakítsa ki az egészségügyi szolgálat pszichofiziológiai bázisát, mentálhigiénés laboratóriumát, valamint dolgozza ki a Mentálhigiénés osztály létrehozásának elgondolását. (10/1985. sz. MN EÜSZF int.) [40].

Ugyancsak a kórház rekonstrukcióval összefüggő bontási és költözési feladatok is végrehajtásra kerültek az év folyamán. Lebontásra került az óvoda, a pszichiátriai osztály oldalépülete, raktárak és barakképületek. Befejeződött a FÜV Bizottság, a Tanulmányi Osztály, a KOKK és a HEAP átköltözése is a kórház üzemviteli épületébe [46].

A Sugárhematológia osztály 1985. november 1-jén szünt meg, és még ebben az évben az andrológiai járóbeteg rendelés kezdte meg a müködését [45]. 
A Tudományos Minősítő Bizottság a tudományos fokozatra felkésztésen résztvevők témavédésének helyéül az $M N$ KKK-t, mint az MN egészségügyi szolgálata tudományos kutató és oktató központját jelölte ki. (61/1985. MN EÜSZF sz. int.) [40].

A honvédelmi miniszter év eleji beszéde visszaköszönt az Egészségvédelmi és Egészségnevelési Bizottságok létrehozásával és a munkahelyi programok elkészitésével kapcsolatos, az MN HF által kiadott parancsban. (83/1985. sz. MN HF pcs.) Ezeket a bizottságokat a „mértéktelen alkoholfogyasztás visszaszorítására irányuló honvédelmi minisztériumi program részeként" kellett létrehozni. Irányadóként az MN Egészségvédelmi és Egészségnevelési Tanács (MN EET) 1983-85. évi munkaterve 1. pontját és az MN Első Egészségvédelmi Konferenciáján elfogadott (a HM által jóváhagyott) „A honvédelmi minisztérium programja a mértéktelen alkoholfogyasztás visszaszorítására" anyagban lefektetetteket kellett tekinteni [40].

$\mathrm{Az}$ év három jelentős rendezvényében részben, illetve rendkívüli módon kivette a részét a szolgálat.

$A z$ 1985. évi jubileumi díszszemle egészségügyi biztositása - a többi érintett szolgálattal és fegyvernemmel együttmüködésben - jelentős feladat volt. Az előszűréses vizsgálatoknál kiemelt szerepet kapott a fizikai és idegi kondíció, az állóképesség (állástürés), a vegetatív idegrendszer, az alsóvégtag és a gerinc, valamint a vérnyomás vizsgálata. A közegészségügyi-járványügyi rendszabályok azonosak voltak az előző díszszemlénél leírtakkal. Az MN KKK-nak 30 bel- és 15 sebészeti típusú ágyat kellett folyamatosan tartalékolnia. A résztvevő állomány helyszíni fogászati ellátására az elhelyezési körletekben (Budapest Nemzetközi Vásár (BNV) és a központi élel- mezési raktár (KÉRA)) fogászati gépkocsikat biztosítottak.

A fekvőbetegeket az MN KKK belgyógyász és sebész szakorvosokból álló „szakorvosi brigád” ellenőrizte [42].

$A z$ év legkiemelkedőbb rendezvénye, illetve az egész egészségügyi szolgálatot megmozgató eseménye az 1985. június 18-28. között megrendezett „Orion-85” Egészségügyi Rendszergyakorlat volt. (043/1985. MN Hadtáp TÖF sz. pcs.) Az előkészületekről és annak terveiről a HM KT ülésen jelentett az MN HF. Jelentése alapján „Az Orion-85 gyakorlat előkészítése az elözetes terveknek megfelelöen folyamatban van" [43]. A gyakorlatról - amely a korszak tábori és háborús egészségügyét legjobban és legobjektívabban értékelte - az arról készült, és a Hadtápbiztosítás folyóiratban az MN EÜSZF-ség Szervezési osztályvezetője, Dr. Villányi Ferenc o. alezredes által megírt cikk adta. Ebből a gyakorlatból kiemelendő, hogy:

„Az 1985. június 18-28. között levezetett "ORION-85" egészségügyi együttmüködési komplex rendszergyakorlat tudatos folytatása volt az 1970-es években megkezdett egészségügyi rendszergyakorlatoknak. Ezek a gyakorlatok - méretüket, a feldolgozandó kérdéseket illetően - fokozatosan szélesedtek, általában az adott ötéves tervidőszakot zárták le és megalapozták a következő ötéves tervidőszak fejlesztési és háborús feladatokra történő felkészítési elveit, gyakorlati módszereit.

$\mathrm{Az}$ első "ORION" gyakorlaton tanulmányoztuk a katona-egészségügyi ellátási rendszer hátországi tagozatának feladatait, problémáit, az állami egészségügyi szolgálattal történő együttmüködés kérdéseit a hadműveleti területről a hátországba szállított sérültek ellátásának megszervezése érdekében."

A következő „ORION” gyakorlaton az elvonuló szárazföldi hadsereg egész- 
ségügyi biztosítása érdekében működő gyógyító-kiürítő ellátási rendszer korszerü összetételének vizsgálata volt az alapvető célunk. Vizsgáltuk a vegyes kórház bázisok és a hátországi ellátási rendszer egymáshoz kapcsolódó működését, valamint a tábori kórházak és hátországi szükségkórházak szervezeti felépítése egységesítésének lehetőségeit.

A távlati fejlesztési célok pontosítása érdekében tanulmányoztuk az állami és katonai egészségügyi szolgálatok összehangolt vezetés-irányítási rendszerének kialakítását is.

$\mathrm{Az}$ ezt követőn „ORION-79” gyakorlat célja volt felmérni a honi területen müködő katonai kiürítő és szükségkórházak szervezetének működési feltételeinek, valamint anyagi-technikai ellátási eszközeinek meglétét. Ezen a gyakorlaton sikerült olyan kísérleti szervezésü egészségügyi alegységeket, segélyhelyeket kialakítani a csapattagozatban is, amelyek jobban megfelelnek a korszerű háború követelményeinek.

A fentiekből látható, hogy az „ORION-85” egészségügyi komplex rendszergyakorlat elött levezetett három gyakorlat méretét tekintve nem fogta át teljes vertikumában az $\mathrm{MN}$ és az állami egészségügyi szolgálat valamennyi ellátó tagozatát, a háborús csoportosítás felvétele a védelmi és a támadó hadművelet időszakában. Továbbá nem került elemzésre az országhatár közelében diszlokáló és megalakuló katonai és polgári kórházak kitelepítésének megszervezése, a tömeges, hagyományos, illetve a tömegpusztító fegyverek által keletkezett nagyszámú sérült ellátásának, a veszteséget szenvedett egészségügyi szervezetek pótlásának lehetőségei és rendszere.

A levezetett három gyakorlat tapasztalatai, valamint a harcászati, hadműveleti és hadászati elvek továbbfejlődése felve- tette egy olyan komplex együttműködési egészségügyi rendszergyakorlat levezetésének gondolatát, mint az "ORION-85”, amely teljes vertikumában - a harcmezötől a hátországig - az egészségügyi szolgálat valamennyi ellátó tagozatát átfogja.

E gyakorlat keretében olyan kérdések feldolgozását tüztek ki célul, amelyek eredményeként értékes tapasztalatokat szerezhettünk:

- az MN Egészségügyi Szolgálatfőnökség, az Egészségügyi Minisztérium, az MN Hátországi Egészségügyi Alakulatok Parancsnoksága, a Polgári Védelem Országos Parancsnoksága és a Központhadtáp Előretolt Lépcső egészségügyi vezető és középirányító szervei feladataival, együttmüködési rendjével és módszereivel kapcsolatban a Magyar Népköztársaság és az MN mozgósításának, az MN csapatai és intézetei háborús csoportosítása felvételének időszakában;

- az egészségügyi csapatok és intézetek mozgósításában, összekovácsolásában, háborús csoportosítása felvételének megtervezésében és végrehajtásában;

- az összpontosítási körletekben tartózkodó csapatainkra az ellenség által mért csapások következményeinek felszámolásában;

- a Magyar Népköztársaság területén, koalíciós front kötelékében, az MN csapatai által vívott védelmi hadművelet időszakában keletkezett sérültek ellátásának megszervezésében, valamint a támadó hadművelet végrehajtása során keletkezett sérültek ellátásában;

- a hadmüveleti területen települt segélyhelyek és intézetek tevékenységének, a sérültek különböző típusú szállítóeszközökön történő nagytávolságú hátraszállításának megtervezésében, megszervezésében és végrehajtásában; 
- az egészségügyi csapatok és intézetek mindenoldalú biztosításának megtervezésében és végrehajtásában;

- az egészségügyi dandárok alkalmazásában, a határbiztosítás, a védelmi és támadó hadmüveletek végrehajtásának időszakában;

- az MN Hátországi Egészségügyi Alakulatok Parancsnoksága helyének, szerepének és feladatainak meghatározásában;

- a biztosítási övben diszlokáló és „M” útján megalakuló egészségügyi intézetek kitelepítésének megtervezésében;

- a tömeges hagyományos és a tömegpusztító fegyverek csapásaitól keletkezett nagyszámú sérült ellátásának megszervezésében;

- a járványos megbetegedések továbbterjesztésének megakadályozásával, a járványgócok felszámolásával kapcsolatos feladatok megszervezésében;

- a felhasznált egészségügyi anyagok tömeges utánpótlásának megtervezésében és megszervezésében;

- az MN egészségügyi csapatok és intézetek, továbbá a középirányító szervek vezetésének megszervezésében és végrehajtásában;

- a hátországban tevékenykedő csapatok segélyhelyei, illetve az egészségügyi intézetek maximális leterheltségének vonatkozásában;

- az egészségügyi csapatok és intézetek pártpolitikai munkájának megtervezésében és végrehajtásában.

Az „ORION-85” gyakorlat levezetésére a VI. ötéves tervidőszak utolsó évében akkor került sor, amikor alapvetően befejeztük a katona-egészségügyi szolgálat erőinek és eszközeinek átszervezését és korszerüsítését. A gyakorlat végrehajtása után, ma már bízvást állíthatjuk, hogy a végrehajtott korszerüsítések alapvetöen sikeresek voltak, kiállták a gyakorlat próbáját.

A szervezeti korszerüsítések eredményeként valamennyi tagozatban növekedett a kiürítő, a sérültellátó kapacitás, javultak a müködtetés, a vezetés, a - hadmüveleti tagozatban - a fentieken túlmenően az oszthatóság, a manőverezés, a mindenoldalú biztosítás feltételei. A hátországi (hadászati) tagozatban, javultak az Egészségügyi Minisztérium és az MN csapatai és intézetei egészségügyi szervezetei közötti együttműködés feltételei, jobban volt összekapcsolható az állami és a katona-egészségügyi szervek tevékenysége a közös feladatok megoldása érdekében.

Mindezek már ezen a gyakorlaton is bizonyították eredményességüket és jó alapot szolgáltattak a gyakorlat elé tüzött célok sikeres megvalósítására.

Összességében megállapítható: a gyakorlat az alapvető célját elérte. A gyakorlaton értékes tapasztalatokat szereztünk az egészségügyi csapatok és tisztek HKSZ, M és összekovácsolási feladatainak megtervezésében, megszervezésében és végrehajtásában, a mindenoldalú biztosítás feladatainak feldolgozásában, a nagytávolságú menetek előkészítésében. Szélesedett látókörünk a „Számítási Év" tervébe betervezett egészségügyi anyagi igények gyártási és átvételi lehetőségeivel kapcsolatban.

Növeltük felkészültségünket és jártasságot szereztünk az ország területén folyó védelmi harctevékenység egészségügyi biztosításában, ezt megelőzően a biztosítási övben diszlokáló és „M”-kor megalakuló egészségügyi intézetek kitelepítésében, együttműködve az állami egészségügyi szolgálat szerveivel.

Tovább fokoztuk felkészültségünket a védelemből indított támadó hadmüvelet 
egészségügyi biztosítási kérdéseinek feldolgozásában.

Egyeztettük elképzeléseinket a Magyar Néphadseregen belül és az MN, valamint az Egészségügyi Minisztérium vonatkozásában mind a hagyományos, mind a tömegpusztító fegyverektől keletkezett nagyszámú sérült ellátásával kapcsolatban.

Ismereteket szereztünk az MN egészségügyi erőinek és eszközeinek a Magyar Népköztársaság lakossága körében keletkezett tömeges sérültek ellátásában való közremüködés kérdésében.

Tisztázásra kerültek az Egészségügyi Minisztériummal kapcsolatos együttmüködés területei és ezek megvalósításának lehetséges változatai.

Elöreléptünk a sebesültszállító vonatok többirányú felhasználásával kapcsolatos kérdések feldolgozásában.

Kirajzolódtak a kontúrjai a Vegyes Kórház Bázisokon belüli vezetés-irányítási, ellátási rendszernek és az ezekkel kapcsolatos további feladatainknak.

Meggyőződtünk arról, hogy a VI. ötéves tervidőszakban végrehajtott szervezeti változások, melyek kapcsán rendszerbe állítottuk az egészségügyi ezredet, az egészségügyi dandárokat és az $\mathrm{MN}$ Hátországi Egészségügyi Alakulatok Parancsnokságát, indokoltak voltak.

$\mathrm{Az}$ Egészségügyi Minisztériumi, és a megyei egészségügyi operatív csoportok igazolták létfontosságukat, de tevékenységük értékelése egyben arra is felhívta a figyelmet, hogy az Egészségügyi Minisztériumban dolgozó, az MN érdekeit képviselő operatív csoportot hivatásos állományú orvosokból célszerü létrehozni. A vezetés-irányítás és működés feltételeit tekintve a gyakorlat igazolta az újonnan kialakított összfegyvernemi típusú szervezeteink nagy előnyét a régebbiekkel szemben. Az egységek és intézetek törzsei az újonnan kialakított szervezetek előtt álló feladatokat alapvetően megismerték, kezdeti jártasságot szereztek szakfeladataik végrehajtásában. A tartalékosok felkészítési rendszerének tökéletesítése terén azonban további feladataok voltak. A megyei operatív csoportok hatáskörét ki kellett terjeszteni a megye területén tartózkodó alakulatoktól minden típusú polgári kórházba érkező saját és szövetséges sérült, beteg nyilvántartására, továbbirányításuk vagy felülvizsgálatuk intézésére.

A bemutató ráirányította a figyelmet arra, hogy tovább kell fokozni erőfeszítéseinket a Szakorvosi Megerősítő Zászlóalj és egyes tábori intézetek funkcionális részlegeinek korszerüsítésére, egyes egészségügyi-technikai eszközök rendszerbe állítása terén.

A hátországi rendeltetésü csapatoknál keletkezett sérültek ellátását vizsgálva, olyan kérdések vetödtek fel, hogy a jövőben nagy jelentőségü lehet a gyógyító intézetek 150-200\%-os leterheltségre való felkészítése.

Az Egészségügyi Minisztériummal és a megyei egészségügyi szervekkel folytatott közös munka lehetőséget nyújtott arra, hogy a tervezésben, szervezésben és irányításban együttmüködésünk minden lényeges kérdését feltárjuk és az eddig megoldatlan gondok, problémák többségére választ találjunk. Mindkét részről megnyilvánult a további közös együttműködés, együttgondolkodás igénye, mind a felkészítés mind a fejlesztés terén" [44].

A harmadik, immáron nemzetközi rendezvény a Varsói Szerződés Tagállamai Katona-egészségügyi szolgálata vezető állománya részére technikai bemutatóval is megfüszerezett $X V$. Koordinációs értekezlet 1985. október 09-18. közötti megrendezése. (0012/1985. MN EÜSZF sz. int.) [42]. 
Azt, hogy milyen technikai eszközöket mutattak be, a 039/1985. számú, az MN Fegyverzeti és Technikai Főcsoportfőnöke és az MN HF együttes intézkedése 1. számú mellékletéből tudhatjuk meg. Ez a paletta az alábbi lehetett:

- DDA-66 fürdető-fertőtlenítő gépkocsi

- PDP-2 fürdető-fertőtlenítő berendezés

- AKVA

- DSB (demineralizáló-sterilizáló berendezés)

- Sebesültszállító gépkocsi

- LUAZ 967 sebesültkihordó gépkocsi

- Kötöző gépkocsi

- Műtő egység felszerelés konténerben

- Mozgó laboratóriumi gépkocsi

- Fogászati gépkocsi

- Bakteriológiai-szerológiai laboratóriumi gépkocsi

- Egészségvédelmi radiológiai laboratóriumi gépkocsi

- Kórbonctani laboratóriumi gépkocsi

- Toxikológiai laboratóriumi gépkocsi

- Vivárium gépkocsi

- Egészségvédelmi laboratórium

- Infúziós laboratórium

- Univerzális sebesültszállító hordágy rögzítö

- Tábori röntgen egység

- Autómaxos fertőtlenítő

- Extenziós készülék asztallal

- Égési asztal

- Sebesültszállító targonca [42]

Ez az év sem volt mentes kiemelkedő rendkívüli eseménytől. A kecskédi - az 1. sz. eü.dd. megalakításához „MZ” (mozgósítás esetére zárolt) anyagokat tárolóraktárbázison, a zárolt készletekböl eltüntek az egyszerhasználatos ampullákból a kábitószert tartalmazók. Ez a rendkívüli esemény újraszabályoztatta a kábítószer tárolására vonatkozó eddigi utasításo- kat. Ettől kezdve az egészségügyi „MZ” készletekben lévő kábítószereket eredeti csomagolási helyükről kiemelve külön, segélyhelyenként összevontan, erősfalú ládában kellett tárolni. A ládákat két lakattal látták el. Az egyik lakat kulcsát az anyagkezelő, a másikat pedig az egészségügyi szolgálatfönök (ha nem volt, akkor a parancsnok által kijelölt személy) örizte. „M" bázisokon az egyik lakat kulcsát az anyagkezelő, a másikat a bázis parancsnoka örizte. (54/1985. MN HF sz. int.) [42].

Ez az év bővelkedett elhalálozás, nyugdijj, betegség, vagy új szervezeti elem beléptetése miatti vezetői kinevezésekben, megbízásokban. Dr. Varga István o. ezds. az MN EÜSZF-ség Gyógyitó osztályvezetöje rokkantsági nyugállományba vonult (01500/1985. HM sz. pcs.), helyére Dr. Fekete István o. alezredes kerül [40]. Prof. Dr. Manninger Jenő orvos vezérőrnagyot, az MN fösebészét 1985. szeptember 1-jével nyugállományba helyezték (0944. sz. HM, 42/1985. MN EÜSZF sz. pcs.) [40], és helyére ugyanettől az időponttól Dr. Farkas József orvos ezredest nevezték ki. (0943. sz. HM pcs., 011/1985. MN EÜSZF sz. pcs.) (42) Dr. Kádár Pál orvos ezredest felmentették az MN KÖJÁL parancsnoki beosztásából és kinevezték 1985. július 1-től az MN föepidemiológusának. (033. HM ÁT, 015/1985. MN EÜSZF sz. pcs.) (42) Dr. Maklári György orvos alezredest 1985. július 1-jével kinevezték az MN KÖJÁL parancsnokává (033. sz. HM ÁT, 09/1985. MN EÜSZF sz. pcs.) (42) Dr. Túry Károly orvos ezredest 1985. február 15-töl az MN Föszemészévé (0119. HM, 04/1985. MN EÜSZF sz. pcs.), Dr. Remes Péter orvos alezredest ugyanettől az időponttól az $M N$ repülö föszakorvosává nevezték ki. (04. HM ÁT, 04/1985. MN EÜSZF sz. pcs.) (42) A késő nyár folyamán elhalálozott 4. sz. Szanatórium parancsnoka Dr. Renczés Alajos orvos ezredes helyére 1985. dec- 
ember 1-jével Dr. Sedivi László orvos őrnagyot nevezték ki. (083. MN HF HMH, 014/1985. MH EÜSZF sz. pcs.) (42) Dr. Kovács Máté orvos ezredest 1985. augusztus 1-jével nyugállományba helyezték (0845. HM és 41/1985. MN EÜSZF sz. pcs.) (40) és helyére Dr. Rékai Miklós orvos örnagyot az MN KKK parancsnokhelyettesévé (067. HM ÁT, 013/1985. MN EÜSZF sz. pcs.), míg Dr. Tóth József orvos alezredest az 1 . sz. KK parancsnokhelyettesévé (017. HM ÁT, 06/1985. MN EÜSZF sz. pcs.) 1985. március 15-től helyezték beosztásba. Ez utóbbi helyére az MN EÜSZF szervező föorvosának (ov.h.) Dr. László Imre orvos alezredest nevezték ki. (07/1985. MN EÜSZF sz. pcs.) [42].

Az 1986-os év fö feladatait már az újonnan kinevezett Kárpáti Ferenc honvédelmi miniszter által jóváhagyott "Munkaterv" konkrétan meghatározta. A személyi állomány ellátása és szolgálati körülményeinek javítása érdekében elkészített terv a szolgálat részére az alábbi területeket ítélte fontosnak:

„1./ A gyógyító-megelőző munka magasabb színvonalon történő ellátása érdekében üzembe kell állítani a felújított MN 1. Katonai Kórházat és az MN KKK részét képező önálló rehabilitációs osztályt Verőcemaroson.

A személyi állomány egészségvédelmét szolgáló, a mértéktelen alkoholfogyasztást visszaszorító „HM Program” megvalósítása érdekében elö kell készíteni és végre kell hajtani az MN Egészségvédelmi Napot. Létre kell hozni az egészségvédelem aktíva hálózatot az MN-ben és biztosítani kell annak hatásos működését. Az Egészségvédelmi Nap tervezett időpontja október 1-15. között került meghatározásra. A csapatorvosi utánpótlás fejlesztésének lehetőségeire és módszereire az orvostisztek anyagi és erkölcsi megbecsülésének javitása érdekében a hazai és NDK egészségügyi föiskolán a képzés beindításának kezdeményezése a csapatorvosi továbbképzési rendszer bevezetésére javaslat kidolgozása a fó feladat.

a) A Varsói Szerződés Tagállamai katona-egészségügyi szolgálatai vezető állománya XV. Koordinációs értekezlete ajánlásainak feldolgozása, a kutatási témák szekcióban való meghatározása, amely a következő területeket foglalta magába:

- sérültek és betegek rehabilitációjának kérdései háborús körülmények között,

- kórházbázisok (front) vezetési módszerek számítógép alkalmazásával,

- áthatoló sugárzás elleni egészségügyi védőeszközök kidolgozása,

- személyi állomány pszichés és fizikai munkavégző képességének növelésére gyógyszerkészítmények előállítása, - új módszerek a hajózó állomány pszichofiziológiás munkavégző képességének emelésére."

A munkaterv mellékletei tartalmazták az MN KKK rekonstrukció folyamatos végzését és felújításként a verőcemarosi Betegotthon felépítési munkáinak befejezését, az MN 1. sz. KK teljes felújításának befejezését, illetve az MN 3. sz. KK föépületének a felújítását. (0057/1986. MN HF nyt.sz. munkaterv) (47).

Ugyancsak visszaköszöntek ezek a feladatok az „MN Hadtáp fejlesztésének főbb irányai és feladatai az 1986-1990 közötti időszakban" címü intézkedésében. (0091/1986. MN HF sz. int.) (48) Az intézkedés értékelte az előző 5 év teljesítményét is. Ezek alapján az egészségügyi szolgálat „növelte segélynyújtó és kiüríto kapacitását, szervezeti korszerüsítéssel javította háborús biztosítása lehetőségeit".

Tovább korszerüsitették a béke egészségügyi ellátás tárgyi feltételeit, ez azonban részben a hivatásos orvosok, másrészt a 
követelménytámasztás hiánya miatt nem eredményezett lényeges javulást a csapatok ellátásában. A kórházak, rendelőintézetek fejlesztésével a korábbiaknál lényegesen kedvezőbb betegellátási feltételek alakultak ki. Eredményes munkája mellett a szolgálatot technikai beszerzési gondok, „M” bázisaik müködési, irányítási rendellenességei, a felülvizsgálati, szanatóriumi beutalási rendszer korszerütlensége terhelték. Az elkövetkezendő 5 évben is fö feladatul az elvonuló és hátországi egészségügyi szervezetek további korszerüsítését, az első orvosi és szakorvosi segélynyújtó kapacitás növelését szabták meg. További anyag és technikai eszközfejlesztést határoztak meg a háborús egészségügyi biztosítás érdekében.

A békeidőszaki egészségügyi ellátás feladatairól az alábbiakat gondolták el:

„Minden tagozatban növelje a béke egészségügyi ellátás színvonalát. Kiemelten végezze a megelőző és rehabilitációs tevékenységet, növelje a meglévő szakmai kapacitások kihasználtságát. Kutassa a személyi állomány egészségi állapotának alakulását, döntően meghatározó főbb betegségcsoportokat, és ezek leküzdésére dolgozzon ki szakmai célprogramokat. Minden szinten növelje az egészségvédelmi munka szervezettségét, a szürés és gondozás eddiginél szervezettebb, módszerében korszerübb megvalósítását. Hatékonyabban és szakszerübben foglalkozzon az egészséges életmódra neveléssel. A csapatsegélyhelyeken növelje a végleges ellátásban részesülők arányát. Gazdaságos megoldásokkal fejlessze a laktanya- és helyőrség szintü ellátást, biztosítva az egyes részfunkciók (fogászati ellátás, szürés-gondozás, sürgősségi ellátás, fekvőbeteg ellátás) szervezeti, technikai, elhelyezési feltételeit. Folytassa tovább a polgári egészségügyi intézmények szakmai lehetőségeinek ki- használását, a csapatorvosi ellátásban a szak-konzíliáriusi rendszer kifejlesztését a területi kórházak felügyeletével.

Folytassa az egészségügyi intézetek szervezeti korszerüsítését. Biztosítsa az építés-beruházási feladatok szakirányítását, kiemelten az MN KKK rekonstrukciója szakmai segítését. Kezdje meg a területi kórházak felújításának tervezését. Az intenzív ellátás fejlesztésével, krónikus ellátó osztályok (részlegek) szervezésével, illetve új profilok kialakításával tökéletesítse az érintett tagozat progreszszív ellátási rendszerét.

Dolgozza ki és vezesse be az MN-ben a mentálhigiénés szolgálatot, teremtse meg annak szervezeti feltételeit.

Biztosítsa az egészségügyi intézetek orvosi gép-, müszerparkjának folyamatos üzemeltetését - az anyagi lehetőségek függvényében -, korszerüsítését és fejlesztését. Folyamatosan szervezze és koordinálja a repülő-hajózó és repülö-müszaki, valamint a földalatti munkahelyen dolgozó állomány rendszeres gyógy-üdültetését.

A szolgálat káder tevékenységében különös gondot fordítson a vezető szakkáderek utánpótlására, a csapatorvosi helyek betöltésére.

Átfogó elgondolás alapján folytassa a gyógyító-megelőző ellátást segítő számítógépes rendszer programok bevezetését" [48].

A már évekkel korábban elöre jelzett, és az éves munkatervben szereplő krónikus ellátásra szoruló betegek számára a „Bakony-I” szervezési feladatokból előrehozták az MN KKK szervezetébe újonnan belépő Szociális Betegotthon (Verőcemaros) rendszerbe állását [48]. Az MN KKK Betegotthonának alaprendeltetéséről, müködésének rendjéről és a beutalásról az MN HF intézkedett (77/1986. MN Hadtáp F. sz. int.) 
„A fokozatos (progresszív) betegellátás elvének megfelelően gondoskodjon az aktív kórházi kezelést nem igénylő, de hosszabb (vagy végleges) időtartamú intézeti szakápolásra, rehabilitációra és általános orvosi felügyeletre szoruló betegek ellátásról."

„Az MN KKK kihelyezett szervezi elemeként, Verőcemaros községben müködik. Vezetését az MN KKK parancsnokának közvetlen szolgálati és szakmai alárendeltségébe tartozó parancsnok (osztályvezető föorvos) látja el."

A beutalásokat az MN KKK parancsnok gyógyító helyettese által elnökölt, a kórház fősebészből és fóbelgyógyászból álló „Beutaló Bizottság” bírálja el. Egyszer három, illetve újbóli három hónapos hosszabbítást a betegotthon parancsnoka és az illetékes föszakorvos, hat hónapot meghaladó időtartamot pedig az MN EÜSZF volt jogosult eldönteni, illetve engedélyezni [49]. Működését 1986. augusztus 1-jével kezdte meg.

Az MN KKK rekonstrukciója kapcsán új helyre költözött az MN Központi Egészségügyi Anyagraktár (KEÜAR). 1986. áprilisától a budapesti Zách utcában kezdte meg az újbóli működését. (23/1986. MN EÜSZF sz. int.) [50]

Az MN HF szigorú hangvételü intézkedést ad ki a gyógyintézetek, illetve orvosok a lött sérülésekkel kapcsolatos jelentési kötelezettségéről. Az intézkedésből kiderült, hogy az érintettek sokszor nem tesznek eleget a jelentési kötelezettségeknek. A lőtt sérüléseket a hadmüveleti ügyeletesen keresztül az ügyészségnek kellett jelenteni. (65/1986. MN HF sz. int.) [49].

1986. május 1-jével újból átalakult a Magyar Néphadsereg Orvosi Tudományos Tanács (MN OTT).

ELNÖK:

Dr. Hideg János o.vőrgy.
Helyettesei:

Dr. Farkas József o.ezds.

Dr. Novák János o.alez.

TAGJAI:

Dr. Horváth István o.ezds.

Dr. Medveczky Pál o.ezds.

Dr. Hajdú Béla o.vőrgy.

Dr. Magyar István o.ezds.

Dr. Birkás János o.ezds.

Dr. Gelencsér Ferenc o.ezds.

Dr. Bagi János áo.ezds.

Dr. Kádár Pál o.ezds.

Dr. Fekete István o.alez.

Dr. Villányi Ferenc o.alez.

Dr. Nagy Dénes gy.alez.

Dr. Remes Péter o.alez.

Dr. László Imre o.alez.

A 16 főből már „csak” 7 fö rendelkezett tudományos minősítéssel, illetve fokozattal. (191/1986. MN EÜSZF sz. int.) [50].

Új bizottságot hoztak létre az egészségügyi szolgálat történetének megírására Dr. Medveczky Pál orvos ezredes, az MN EÜSZF első helyettesének vezetésével. A kidolgozási határidő 1987. december 15., az anyagok értékelése 1988. I. félévére került meghatározásra. (61/1986. M EÜSZF sz. int.) [50].

A minőségi szakmai munka érdekében a szívinfarktuson átesett katonák egészségügyi rehabilitációja érdekében kiadásra került az MN Főbelgyógyászának 1/1986. számú direktívája, amely az akkor korszerü WHO (Világ Egészségügyi Szervezet ENSZ) ajánlásai alapján készült el. (60/1986. MN EÜSZF sz. int.) [50].

Ebben az évben készítette el az MN Egészségügyi Szolgálata az egyik legkiemelkedőbb és legjelentősebb előterjesztését a HM KT számára: „az MN személyi állománya béke egészségügyi ellátásnak helyzetéröl és fejlesztésének föbb irányairól". Az előterjesztés az utolsó ilyen jellegü jelentés időpontjától, 1979- 
től 1986. októberéig terjedő időszak béke egészségügyi ellátásáról szól, tehát a korszakot jelentősen átfogó és azt objektívan bemutató, adatokkal bőségesen ellátott dokumentum. (00179/30/1986. MN EÜSZF sz. előterjesztés) [51].

$\mathrm{Az}$ információkban igen gazdag áttekintést gyakorlatilag szó szerint érdemes megörökíteni, hisz összehasonlító epidemiológiai kutatások során kiemelkedő értékkel és jelentőséggel bírhat. Így néhány sor kihagyásával a következők írhatók le a szolgálati akkori helyzetéről, eredményeiről, a személyi állomány egészségi állapotát jellemző adatokról és állapotokról:

„A hivatásos és továbbszolgáló állomány korösszetételében - 15 éves periódusra visszatekintve - az elmúlt években növekedett a 21-40 éves korcsoportba tartozók aránya (1970-ben 59\%, 1985-ben 64\%). Ez a változás kedvező és összességében a hivatásos állomány átlagéletkorának csökkenését (megfiatalodását) eredményezte. A 41-50 éves korcsoportba tartozók létszámaránya csökkent (35\%ról 20-21\%-ra). Az 51 év feletti idősebb korosztályok százalékos aránya (5-6\%-ról 15-16\%-ra) növekedett. Ez utóbbi változás az egészségügyi ellátás iránti igények szükségszerü növekedését eredményezte.

A megelőző-gyógyító tevékenység hatékonyabbá tétele érdekében az elmúlt évek során rendszerré vált a hivatásos állomány évenkénti kötelező szűrővizsgálata. A vezető állomány meghatározott kategóriáinál (mintegy 1200 fö) a szűrést a katonai kórházak szakorvosai, az egyéb állománykategóriáknál a csapatorvosok végzik. A szürővizsgálatokban évente mintegy 25000 fö vesz részt.

A szürővizsgálatokon a megjelenés megfelelő (88-92\%-os). Az eredményeket értékelve a hivatásos állomány egészségi állapota az elmúlt öt évben gyakorlati- lag nem változott. Átlagosan az állomány közel 65\%-a gyakorlatilag egészséges és a csapatorvosi gondozást igénylöket is ideszámítva az állomány mintegy 85\%-a szolgálatképes. A szürési adatok azt is tükrözik, hogy az életkor és a vele együtt járó szolgálati évek növekedésével a gyakorlatilag egészséges minősítésűek számaránya gyors ütemben csökkent. Így 46 év felett az MN átlag felére, 51 év felett pedig annak harmadára redukálódott. A leggyakrabban előforduló megbetegedések sorrendje: mozgásszervi $(9,8 \%)$, szív-érrendszeri $(8,1 \%)$, emésztőrendszeri $(6,8 \%)$, és idegrendszeri betegségek (6,7\%).

$A z M N$ vezető állomány részvétele a szürővizsgálatokon megfelelő (92-95\%os). Az állomány 47,4\%-a gyakorlatilag egészséges, $45,1 \%$-a igényel rendszeres szakorvosi gondozást, kórházi kivizsgálásra, gyógykezelésre 7\% szorul, egészségügyi alkalmasságát - évek óta - 0,5\%nak kell felülvizsgálni. A gondozottak valamivel több, mint kétharmada igényel regeneráló pihentetést, illetve szanatóriumi ellátást, mivel a vezető állomány körében a szív-érrendszeri és a mozgásszervi megbetegedések aránya az $\mathrm{MN}$ átlagát jelentősen meghaladja. Egészségi állapotuk rendszeres ellenőrzésével, folyamatos gondozásukkal, egészségügyi rehabilitációjukkal szolgálatképes arányuk tartósan 90\% felett van.

A szürési rendszer korszerüsítése céljából az MN ROVKI-ban modell-kísérleteként szakorvosi szürővizsgálatot végeztek az MN Légvédelmi és Repülő Parancsnokság repülést kiszolgáló mérnök-műszaki, a rádiótechnikai csapatok nagyfrekvenciás sugárzásnak kitett hivatásos- és a földalatti harcálláspontok hivatásos és polgári állománya (összesen mintegy 2000 fö) körében. Az orvosi vizsgálatokat kiegészítették a hazánkban leggyakoribb halálozást okozó szív-érrendszeri betegségek koc- 
kázati tényezőinek vizsgálatával. A kockázati tényezők előfordulásának gyakorisági adatait, a vizsgálatba bevontak száma (1650 férfi, 334 nő) alapján MN szinten modellnek tekintjük. A vizsgálatok eredményei azt bizonyítják, hogy a vizsgáltaknak 40\%-a szív naponta több mint 20 cigarettát, emelkedett vérnyomásértékek 25\%-ban, EKG eltérések 10\%-ban, vérzsír és vércukor szint emelkedés 20 , illetve $5 \%$ os gyakorisággal fordult elö. A $10 \%$ feletti testsúlytöbblet gyakorisága 15-20\% körül van. Ezek a tényezők amellett, hogy hajlamosítanak a szív-érrendszeri megbetegedésre, más betegségek kialakulásában is szerepet játszanak, így a dohányzás a tüdőrák, az elhízás a kőbetegségek (epekő, vesekő), illetve a cukorbetegség kialakulását segítik elö.

Kérdőíves módszerrel vizsgálták a gyógyszer és alkoholfogyasztást. Értékelhető eredményt nem kaptak, mert ezeket a kérdéseket a vizsgáltak többsége nem válaszolta meg. A kockázati tényezők előfordulási gyakorisága az életkor elörehaladtával nőtt, ugyanígy növekedett azok száma is, akiknél halmozottan (3 vagy több kockázati tényező) fordul elő. A kockázati tényezők feltárása és megszüntetése több krónikus megbetegedés megelözésének leghatékonyabb eszköze. Ezen tényezők vizsgálata a szürővizsgálatok további korszerüsítését is jelentik.

A katonai kórházakban kezelt hivatásos állomány megbetegedési adatait elemezve megállapítható, hogy a leggyakrabban előforduló betegségcsoportok közül sorrendben az emésztőszervi (18$20 \%$ ), a szív-érrendszeri betegségek (1719\%), az idegrendszer múködési zavarai (11-13\%), a balesetek (9-12\%), és a mozgásszervi elváltozások (8-11\%) szerepelnek. Évente kórházainkban mintegy 3000 hivatásos katonát kezeltek, ez a teljes állomány $12 \%$-át tette ki.
Az egy betegre eső szolgálatmentes napok száma 25 napról 18,2 napra csökkent. Ennek ellenére a betegek számszerü növekedése miatt az összlétszámra vonatkoztatva az egy före eső egészségi okból a szolgálatból kiesett napok száma 2,6-ról 3,5-re emelkedett.

Az MN polgári alkalmazotti állomány megbetegedési statisztikájával nem rendelkezünk. A KKK-ban a polgári alkalmazottak táppénzes helyzete, az MN ROVKI-ban a szűrt nők adatainak vizsgálatai alapján 34,1\%-uk gyakorlatilag egészséges. Kezelést nem igénylő betegségben szenvedett 9,9\%; csapatorvosi gondozásra 13,5\%; szakorvosi ellátásra 31,7\%-a szorult. Kórházi ellátást igényel 24,3\%-uk. A táppénzes \% $(12,2-13,8)$ igen magas, azonban mintegy fele gyermekápolás címén keletkezett. A kedvezőtlen tendenciák részletesebb feltárást és megfelelö intézkedést igényelnek.

A sorállomány egészségi állapotát jellemző megbetegedési adatok struktúrájában az elmúlt években jelentős változás nem következett be. Első helyen a heveny légúti $24,5 \%$, a második helyen a sérüléses $22,2 \%$, a harmadik helyen az emésztőszervi betegségek (7,8\%), a negyedik helyen a különböző funkcionális idegrendszeri kórképek (5,5\%) álltak. A bevonuló sorállomány fogászai helyzete továbbra is kedvezőtlen. Hosszú idő óta $97 \%$-uk valamilyen fogászai ellátásra szorul (2. melléklet).

A sorállomány kórházi kezelést igénylő betegségei sorrendben: balesetek (1720\%), emésztőszervi (15-18\%), légzöszervi betegségek (10-13\%), működési jellegü idegrendszeri (10-12\%), valamint érzékszervi (10-11\%) károsodások (2. sz. melléklet). Kórházaink évente mintegy 11000 sorkatonát kezeltek, ez a teljes állomány 16\%-a. Az éves összkiképzési napokból betegség miatt kiesett napok 
aránya az elmúlt évben 2,5-2,6\% körül mozog. Az egy betegre jutó szolgálatmentes napok száma ezen idő alatt 16,9ről 14,8-ra csökkent. Ez azt jelenti, hogy az enyhébb lefolyású, rövidebb ideig tartó megbetegedések kerültek előtérbe."

\section{„A közegészségügy és járványügy} területén a Néphadseregben általában kedvezőbb a helyzet, mint a polgári életben. Ebben a hadseregen belül érvényesülő nagyobb szervezettség és fegyelem mellett szerepet játszik az is, hogy a parancsnokok tisztában vannak a közegészségügyi veszélyeztetés, különösen a járványos, fertőző megbetegedések közvetlen hatásával a csapatok harckészültségére. Mindezeknek és az egészségügyi szolgálat hatékony megelőző tevékenységének köszönhetően az elmúlt években a harckészültséget veszélyeztető járvány nem fordult elő. A tömegesen fellépő fertőző megbetegedések aránya az országos gyakoriság 20-30\%-át érte el.

A korábbi időszakban az elhelyezés, az élelmezés és munkakörülmények terén elért higiénés fejlődés a kedvezőtlen gazdasági körülmények következtében az utóbbi 2-3 évben érzékelhetően stagnált. A közművek karbantartási problémái fokozódnak, ez kedvezőtlenül növeli a potenciális közegészségügyi-járványügyi veszélyeztetést.

A katonai KÖJÁL és a kecskeméti KÖJÁL decentrum, illetve az ezek bázisán müködő csapattagozatban felállított közegészségügyi-járványügyi felügyeleti rendszer alaprendeltetésü feladatait hatékonyan látta el. A többi területi kórház bázisán tervezett újabb KÖJÁL decentrumok létesítése anyagi feltételek hiányában nem valósult meg. Erre a fejlesztésre feltétlenül szükség van, létrehozásukat jelen tervidőszakban tervezzük." A jelentéshez csatolt, az állomány szürövizsgálatáról, a járóbeteg szakrendelésen megjelentekről, illetve kórházi ápolásról, valamint a sorköteleseket jellemző mutatókról a 2. sz. mellékletben lehet adatokat és információkat gyűjteni. Az előterjesztésben említett és az MN ROVKI-ban már kikísérletezett szürővizsgálati módositásokat a 63/1986. sz. intézkedés valósítja meg, mellyel az eddig érvényben lévő - és már akkor is korszerünek tartott - 39/1983. MN EÜSZF sz. intézkedést pontosították. Ennek lényege az orvosi titoktartás erősítése és egy új öszszesítő mellékletnek, a rizikófaktoroknak (dohányzás, testsúly, cukorbetegség, zsíranyagcsere zavar, életmód, magas vérnyomás) felmérésének az elrendelése volt. Ez az intézkedés rendelte el 1988. január 1-jei határidővel az aktív gondozói munka általános és speciális szakmai irányelvének kidolgozását is [50].

A minöségi szakmai munka támogatását jelentette, hogy az MN KKK-ban az országban akkor harmadikként - egy harmadik generációs CT került telepítésre, amelyet néhány év múlva $U H$ diagnosztikus berendezés is követett. Rendszerszervezési és számitástechnikai osztály alakult 6 fövel. A Mellkas sebészeti osztály megszüntetése után az érsebészeti osztály önálló állománytáblát kapott [45].

December 1-jén az MN 1. sz. KK-ban befejezték a felújitás utáni átadás-átvételt. A nyár folyamán az Állami Egészségügyi Szolgálattal együttműködésben végrehajtott „Balaton-86” egészségügyi törzsvezetési gyakorlat jó szinten került lebonyolításra [48].

$A z$ elözö éveket összefoglaló „Tájékoztató jelentés" amelyet az MN VKF Anyagtervezési és Közgazdasági Csoportfőnökség terjesztett elő júniusban a HM KT elé, az egészségügyi szolgálatról az alábbiakat jelenti:

„Az egészségügyi ellátás létesítményfeltételei terveinket meghaladó mértékben 
javultak. Üzembe helyezésre került a győri 300 ágyas kórház, a nagykanizsai helyőrségi rendelö, a kecskeméti rendelöintézet, a pécsi rendelöintézet és befejeződött a pécsi kórház bővítése. (00226/11/84. MN VKF ATCSF) [43].

Nagyobb jelentőségű személyi váltásra, illetve kinevezésre csak az Egészségügyi Szolgálatfönökség állományában történt. Dr. Horváth István o. ezds-t az MN eü. szolgálatfönök első helyettesét 1986. február 01-től más fontos állami beosztásba - az egészségügyi minisztérium szervezési fóosztály vezetöjének - került. (48) Dr. Fekete István o. alez-t a 01725/1985. HM sz. pcs-al 1986. január 1-től a Gyógyító osztály, míg Dr. László Imre o. alez-t pedig a 0785/1986. HM sz. pcs-al 1986. augusztus 1-től a Szervezési osztály osztályvezetöjének nevezték ki [52].

$\mathrm{Az}$ 1987-es esztendő ugyanazzal az eseménnyel kezdődött, mint amivel az elöző év befejeződött, nevezetesen az $M N$ 1. sz. KK átadása utáni visszaköltözésével. Január 2-4. között az MN KKK-ban müködő valamennyi járóbeteg szakrendelés, a felvételi iroda és a kartonozó települt vissza. A Mentőrészleg január 2-án, a III. Belgyógyászati osztály január 3-án, az Ideggyógyászat január 8-án, a műtéti osztályok (sebészet, fül-orr-gége, szülészetnőgyógyászat, intenzív és gyermekosztály, valamint a központi sterilizáló) február 28 -ig települt vissza. Az egész év, annak ellenére, hogy az áttérés időpontja 1987. március 01., gyakorlatilag - föleg a csapatoknál - költözésekből és diszlokációkból állt, hiszen megkezdődött az előző évben jóváhagyott Bakony-II hadiszervezetei megalakítási tervének végrehajtása, azaz az ezred-hadosztály struktúráról a dandár-hadtest szervezetre való áttérés.

A központi egészségügyi szervek diszlokációjában is történtek változások, és a csapatok csoportosításhoz alkalmazko- dó területen helyezték el őket, illetve készenléti idejüket a biztosítandó erők mobilitásához pontosították.

Háborúban az MN eü. szolgálatfönökség alárendeltségében lévő, 1. sz. eü.dandár (eü.dd) [1.dd.pság, 222. sz. híradó század (hír.szd.), 201 sz. műszaki század (mű.szd.) 209. sz. kiszolg.elló.zl., 232. sz. VEA, 110, 111, 112, 129, 132, 143, 70, 71, 144, 191. sz. TTSK, 80, 81, 82, 169. sz. TTBK, 69. sz. tábori többprofilú belgyógyászati repülő kórház (TTBRK), 88, 147, 159. sz. KSK, 84, 184.sz. TFK, 86, 149. sz. OKA, 99. sz. EJO, 234. sz. SZMZ, 151. sz. sgk.szd. 120, 196. sz. eü.o., 239. sz.áeü.o.], az Oroszlány-Tata-Tatabánya-Kisbér-Zánka-Balatonfüred-Balatonalmádi és Balatonkenese körletében az Észak-Dunántúlon alakult meg. Készenléti ideje M-1-24.00 lett.

A 2. eü.dd. [dd.pság, 223. sz. hír.szd., 205. sz. műsz.szd., 216. sz. kiszolg.elló.zl., 223. sz. VEA, 77, 145, 99, 100, 113, 114, 104, 105, 157, 158. sz. TTSK, 165, 171, 174, 175. sz. TTBK, 176. sz. TTBRK, 200, 151, 253. sz. KSK, 146,181.sz. TFK, 150, 227. sz. OKA, 119. sz. EJO, 235. sz. SZMZ, 93.sz. Sgk.szd.] Komló-VasasSzentlőrinc-Sásd-Szekszárd-Bonyhád és Mecseknádasd körletében a Dél-Dunántúlon alakult M-1-24.00 készenléti idővel.

A 3. eüdd. [dd.pság, 237.sz.hír.szd., 208.sz. müsz.szd., 238sz.. kiszolg.elló. szd., 107. sz. VEA, 136, 137, 138, 139, $125,126,127,128,153,154$. TTSK, 115, 172, 83, 166. sz. TTBK, 167. sz. TTBRK, 185, 271, 293. sz. KSK, 178, 182. sz. TFK, 190, 219. sz. OKA, 208. sz. EJO, 92. sz. SZMZ, 206. sz. sgk.szd., 211.sz. eü.o.], Örkény-Dabas-Kerekegyháza-ÓpusztaszerKiskundorozsma-Kakucs-Lajosmizse körletében a Duna-Tisza közben, KözépMagyarországon alakult meg. Készenléti ideje M-3 24.00 óra volt.

A $18 \mathrm{db}$ sebesültszállító vonat (sv) [1-16, 152, 157.sz. sv.] Maglód, Mór, 
Dunaharaszti, Taksony, Dömsöd, Kunszentmiklós, Fülöpszállás, Pusztavám, Bodajk, Ajka (2), Oroszlány, Alsóörs, Csengőd, Ágasegyháza, Zánka-Köveskál, Soltvadkert állomásokon alakultak meg M-3-5 napos készenléti idővel.

$\mathrm{Az}$ egészségügyi tartalék, amely a szovjet Déli-Hadsereg Csoport parancsnok át-alárendeltségébe átadásra került $[74,75,76,101,103,121,122,123,124$, 133.sz. TSK, 164, 116. TBK, 179, 180. sz. TFK, 148, 102. sz. KSK, 87. sz. OKA], Dömsöd-Dunavarsány-Taksony körletében helyezkedett el, a készenléti ideje M-2-24.00 óra volt.
Háborúban a MN HEAP alárendeltségében lévő, csapatok és kórházak az alábbi elrendezésben diszlokáltak, szintén készenléti idő pontosítással.

Mozgó kórház csoport [MKCS fönökség, 65.kiszolg.elló.szd., 241. sz. VEA, 242, $243,244,245$. sz. TTSK, 246, 247. sz. TTBK, 236. sz. TFK, 249.sz. OKA, 205. sz. sgk. szd.], Acsa-Jászkísér-Jászberény-RáckeveBugyi körzetében alakult meg és M-1-M-324.00-ás készenlétü szervezetek voltak.

A békében meglévő kórházak számára a háborús időszakban ikerkórház szervezetet, illetve hadi helyőrséget is kijelöltek. Így:

\begin{tabular}{|c|c|c|}
\hline $\begin{array}{l}\text { Az MN HEAP } \\
\text { parancsnokság }\end{array}$ & \multicolumn{2}{|c|}{ Bugyi } \\
\hline $\mathrm{MN}$ KKK & \multicolumn{2}{|c|}{ Kalocsa (hadihelyőrségek) } \\
\hline 1.rlg. & \multicolumn{2}{|c|}{ Budapest } \\
\hline 2.rlg. & \multicolumn{2}{|l|}{ Hatvan } \\
\hline Betegotthon & \multicolumn{2}{|c|}{ Verőcemaros } \\
\hline 1. KK & \multicolumn{2}{|c|}{ Balatonkenese (hadihelyőrségek) } \\
\hline 1. rlg. & \multicolumn{2}{|c|}{ Budapest Királyhágó u. } \\
\hline 2. KK & \multicolumn{2}{|c|}{ Hódmezővásárhely (hadihelyőrség) } \\
\hline 1. rlg. & \multicolumn{2}{|c|}{ Kecskemét } \\
\hline 3. KK & \multicolumn{2}{|c|}{ Harkány (hadihelyőrségek) } \\
\hline Kihelyezett rendelő & \multicolumn{2}{|l|}{ Nagykanizsa } \\
\hline 1. rlg. & \multicolumn{2}{|l|}{ Pécs } \\
\hline 6. KK & Győr & Esztergom (hadihelyőrségek) \\
\hline 1. rlg. & \multicolumn{2}{|l|}{ Győr } \\
\hline 4. . sz. Szanatórium & $\begin{array}{l}\text { Hévíz } \\
\text { 1. rlg. Hévíz }\end{array}$ & Hévíz (hadihelyőrségek) \\
\hline 5.sz. Szanatórium & $\begin{array}{l}\text { Balatonfüred } \\
\text { 1. rlg. }\end{array}$ & $\begin{array}{l}\text { Balatonfüred, Horgász u (hadihelyőrségek) } \\
\text { Balatonfüred }\end{array}$ \\
\hline MN ROVKI & Kecskemét & $\begin{array}{l}\text { Hódmezővásárhely (hadihelyőrségek) } \\
\text { 1. rlg. Kecskemét }\end{array}$ \\
\hline MN KORI & $\begin{array}{l}\text { Kaszópuszta } \\
\text { (Somogyszob }\end{array}$ & Kaszópuszta (hadihelyőrségek) \\
\hline MN KEÜAR & Budapest & Jászberény (hadihelyőrség) \\
\hline - Kirendeltség & Acsa & Acsa \\
\hline - Kirendeltség & Jászberény & Debrecen (hadihelyörségek) \\
\hline - Kirendeltség & Békéscsaba & Békéscsaba \\
\hline - Kirendeltség & Békéscsaba & Békéscsaba \\
\hline
\end{tabular}

$\mathrm{Az}$ egészségügyi osztagok (201, 202, 217, 218, 219, 220. sz.) a 83. sz. áeü.o., a 105. sz. EJO, a 248. sz. OKA és 326. sz. sgk. szd. A Mór-Vértesacsa-BalatonakarattyaBalatonfüred-Zánka-Ráckeve-Nyárapát-
Acsa helyőrségekben alakultak meg, illetve érték el alkalmazási készségüket.

Az elözö évi szakmai fejlesztések következtében, megkezdödött az érbetegek ellátása az önálló érsebészeti osztályon [45]. 
A Klinikai laboratórium 2 főorvosa kidolgozta az ország és a hadsereg első klinikai laboratóriumi konténerét, amely békében és katasztrófa körülmények között egyaránt müködőképes volt [45].

Dr. Záborszky Zoltán o. ezds. az MN KKK Traumatológiai osztály osztályvezető föorvosa a Debreceni Orvostudományi Egyetem újonnan megalakult Traumatológiai Tanszékének első professzora lett [45].

$\mathrm{Az}$ év végén, december 9-én az $M N$ egészségügyi szolgálatfönök referátumában - melyet az MN hadtáp vezetői állománya részére a gazdasági-társadalmi kibontakozás feladatait meghatározó értekezletén mondott el - összefoglalta az előző, továbbá az 1987. évben elért eredményeket, és elörevetítette a jövöre vonatkozó elgondolásokat.

Sok helyen visszaköszönnek az elmúlt évi, Katonai Tanács elé terjesztett anyaggal kapcsolatos döntések végrehajtásának eredményei, úgy, mint a csapatorvosok pályántartása érdekében megtett lépések, a szürővizsgálatok előzetes kísérletek és próbák utáni bevezetése 1988-ban, a csapattagozat személyi feltételinek biztosítása az 1. sz. KK-ban és Veröcemaros rendszerbe állításának kedvező hatásai az ellátás minőségi fejlődésére.

Az új diagnosztikai eszközök beszerzé$s e$ - rtg., automata labordiagnosztika és intenzív terápiás fejlesztés, komputertomográf üzembe helyezése $60 \mathrm{mFt}$ értékben - szintén a fenti célokat szolgálták.

Megjelentek a gazdaságosságra való törekvés első jelei. Elöször lehetett hallani az „egyes betegre vonatkozó költségelszámolásra” való felkészülésről.

$\mathrm{Az} \quad \mathrm{MN}$ KKK rekonstrukcióhoz kapcsolódó feladatok - érsebészeti és mentál-higiénés osztályok rendszerbe állítása - kiemelten kerültek kezelésre.

A szanatóriumi beutalási rendszer módositása, illetve szigorítása révén a 100
000 fö jogosultra Hévízen 3 400, Balatonfüreden 1500 fö kezelését hajtották végre. A káderutánpótlás javitásával - a Kirov Katonaorvosi Akadémián újból orvosképzés beindításával - az 5. hadsereg igényeit majdnem sikerült kielégiteni, amelynek eredményeként az 1 . és 2 . hadtest alárendeltségébe tartozó valamennyi dandár hivatásos orvossal rendelkezett. A referátum nem ítélte kedvezőnek a férfi és női orvosok arányát, és bejelentette, hogy a további elnőiesedés megakadályozása érdekében 1987-től csak fiúk jelentkezését fogadták el a HM ösztöndíjra. Az ekkor beiskolázásra került 46 főből - egyedi elbírálás alapján, és kizárólag katonaszülők gyermekeként - 3 fö volt a leány.

A Pécsi Orvostudományi Egyetemmel a katona-orvosi fakultás beindítására előkészítő tárgyalásokat folytattak, amely egy új ösztöndíj rendszer kialakítását tette volna lehetővé. Lényege az volt, hogy a leendő hallgatók más karra ne tudjanak átmenni.

A háborús felkészités érdekében az év folyamán vérszállitó gépkocsi és sebesültszállitó vonatok kerültek rendszeresítésre és fejlesztésre, 80 millió Ft értékben pedig az MN lejáratos gyógyszereit frissítették.

A jelentés végén az MN egészségnevelési tanácsának fontosságáról tett említést, hisz ezzel sikerült látható módon is a kormány egészségmegőrző programjához csatlakozni [53].

A vezető állományból 1 fö, $D r$. Kurucz Tibor gy. ezds. az MN fögyógyszerésze a 024/1988. sz. HM paranccsal került szolgálati nyugállományba 1987. december 1-jei hatállyal [54].

Az 1988 évi feladatokat az MN hadtápfőnökség 1988. évi munkaterve körvonalazta. Az előző év értékelésében a terv külön foglalkozott azzal, hogy a nehézségek ellenére folytatták az MN KKK rekonstrukcióját. 
Elrendelték, hogy az év folyamán ki kell dolgozni, a vegyes kórház bázisoknál (VKB) a katonasérültek és betegek dokumentációját, valamint azokat a polgári kórházaknak át kell adni.

Ugyancsak el kellett készíteni a katonasérültek és betegek háborús normák szerinti járandósági biztositási rendszerét [55].

A szürővizsgálatok rendszerének átdolgozása is megtörtént, amelyet mind a munkaterv, mind pedig az előző évi egészségügyi szolgálatfönöki referátum is indokolt $[53,54,55]$.

Ez alapján minden állománykategóriát 3 évenként kellett szürni. A hivatásos és továbbszolgáló katonák teljeskörü vizsgálatát 1991-ben kellett végrehajtani. Az 1988-ról elmaradtak szürését 1989ben kellett pótolni. A kinevezett polgári (Ki.pa.) állomány teljeskörü szűrővizsgálatát 1989-ben szervezték meg, kötelező tették a nők nőgyógyászati rákszürését is. (46/1988. sz. MN EÜSZF-i int. az MN ht. és tsz. állomány gondozásáról szóló 39/1983. sz. MN EÜSZF int. módosításáról és kiegészítéséről) [54].

Az egészségügyi tisztképzést - az orvostudományi egyetemek egészségügyi föiskolai karán - szeptember 1-jével indították be [55].

A kardiológiai gondozás és rehabilitáció MN szintü végrehajtását is kidolgozták, melyekhez MN föszakorvosi direktívák kidolgozására és pontosítására is szükség volt [55].

Felülvizsgálták és újra szabályozták a tényleges állomány egészségügyi felmentésének és a Ki.pa. állomány táppénzbe (keresőképtelen állományba) vételi szabályait [55].

Az MN HEAP feladatait az MN HF jogkörében újraszabályozták [55].

$\mathrm{Az}$ előző év beszerzései nyomán rendszerbe állt az MN KKK laboratóriumában a VKM vércsoport meghatáro- zó és az összeférhetetlenség kimutatására szolgáló műszer [55].

Az Országos Hematológiai és Vértranszfúziós Intézet sokirányúan segítette a Vérellátó osztály működését [45].

Az MN KKK Baleseti sebészeti osztályán új röntgen, ambuláns mütö és sokktalanitó került kialakításra. $A z$ „M”-bázisok tevékenységének szabályozására az előző években már említett visszaélési és szabálytalan tárolásból eredő nagy összegű anyagi károk megelőzésére szolgáló követelményrendszert adtak ki, amely a kórházparancsnokok felelösségét jelentősen megnövelte. (07/1988. sz. MN HTPF pcs.) [56].

Ugyancsak megszigorították a szanatóriumi beutalás, felvétel rendjét. Így olyan beteg, akinek akut ellátásra van szüksége, nem kerülhetett beutalásra. Az Elsőfokú Egészségügyi Felülvizsgáló Bizottság (FÜV) és a Repülő Orvosi Bizottság $(\mathrm{ROB})$ negyedévenkénti ülésekre és a katonabetegek külön nyilvántartására lettek kötelezve. A vezető állomány keretével az MN EüSzF-ség Gyógyító osztálya rendelkezett. Egyes osztályvezető föorvosokat részleges előjegyzési jogkörrel ruháztak fel. Az indokolatlanul beutalt betegeket haza (vissza) kellett küldeni. $\mathrm{Az}$ intézkedés mellékletében külön szabályozták az abszolút javallatokat és ellenjavallatokat [54].

Tovább folytatták az MN KKK és a csapatsegélyhelyek rekonstrukcióját, illetve korszerüsítését. Véglegesen kialakult az MN KEÜAR a Zách utcában [55].

A VSZ tagállamainak fösebészei 1988. december 6-7-én megtartott értekezletén képviseltette magát a szolgálat.

Ebben az évben nagyon kevés volt a személyügyi változás. Dr. Kádár Pál o. ezds. az MN fóepidemiológusa 1988. július 01-jei hatállyal került nyugállományba (0327/1988. sz. HM pcs.) (54), helyette a feladattal Dr. Maklári György o. alez. az 
MN KÖJÁL parancsnoka került megbízásra (029/1988. sz. HM AT pcs.) [57].

1988. szeptember 1-jén Dr. Szalkai Iván o. alez-t kinevezték az MN 3. sz. KK parancsnokhelyettesévé (041/1988. HM AT pcs.) (57), míg Frolyó Imre alez-t az MH HEAP törzsfőnökévé (079/1988. sz. MN HTPF pcs.) [57].

$\mathrm{Az}$ év végére teljességgel kialakult az MN egészségügyi szolgálata kórházi és intézeti vezetőinek végleges névsora, amelyet érdemes megörökíteni az utókornak. Dr. Hideg János o.vőrgy. MN EÜSZF

Dr. Medveczky Pál o. ezds. MN EÜSZF.h.

Dr. Villányi Ferenc o. alez. MN EÜSZFség Szervezési osztályvezető

Dr. Fekete István o. alez. MN EÜSZF-ség Gyógyító osztályvezető

Dr. Birkás János o. ezds. MN KKK parancsnok

Dr. Rékai Miklós o. alez. MN KKK pk.h.

Dr. Király Margit o. ezds. MN KKK pk.gy.h.

Dr. Bellák Ervin o. alez. MN KKK pk.tud.h.

Haraszti György alez. MN KKK pk.agi.h.

Dr. Maklári György o.alez. MN KÖJÁL pk., mb.föepidemiológus

Dr. Túry Károly o.vőrgy. MN főszemész

Dr. Magyar István o. ezds. MN föideggyógyász

Dr. Novák János o. ezds. MN égési föszakorvos

Dr. Farkas József o. vőrgy. MN fösebész

Dr. Hajdú Béla o. vőrgy. MN föbelgyógyász

Dr. Kádár Pál o. ezds. MN főepidemiológus 1988. július 1-ig

Dr. Remes Péter o. ezds. MN repülő föszakorvos (MN ROVKI pk.)

Dr. Bagi János áo. ezds. MN föállatorvos

Dr. Hangai Géza gy. örgy. MN fögyógyszerész

Dr. Sepsey Szabolcs o. ezds. MN Közp. FÜV bizottság elnök
Dr. Sultész József o. ezds. MN 1. KK pk.

Dr. Tóth József o. alez. MN 1. KK pk.h.

Dr. Vollner György o. alez. MN 1. KK pk.gy.h.

Dr. Polgár József o. ezds. MN 2. KK pk.

Dr. Szedresi István o. alez. MN 2. KK pk.h.

Dr. Oláh Lajos o. alez. MN 2. KK pk.gy.h.

Dr. Csengeri Attila o. alez. MN ROVKI pk.h.

Dr. Pozsgai Attila o. örgy. MN ROVKI pk.tud.h.

Dr. Aracsi László o. ezds. MN 3. KK pk.

Dr. Bene Ambrus o. alez. MN 3. KK pk.gy.h.

Dr. Ferencz Lajos o. örgy. MN 3. KK pk.h.

Dr. Törő István o. ezds. MN HEAP pk.

Dr. Pintér Attila o. örgy. MN HEAP pk.h.

Keserü György gy. alez. MN HEAP pk.ag.h.

Mózes Gábor alez. MN HEAP TÖF

Lefler László őrgy. MN HEAP pk.pol.h.

Dr. Ónodi István o. ezds. MN 6. KK pk.

Dr. Lehoczky Miklós o. örgy. MN 6. KK pk.h.

Dr. Hidvégi Tibor o. alez. MN 6. KK pk.gy.h.

Dr. Sedivi László o. őrgy. MN 4. Szanatórium pk.

Sándor János alez. MN 4. Szanatórium agi.pk.agi.h.

Dr. Kovács Kálmán o. alez. MN 4. Szanatórium pk.gy.h.

Dr. Gyökössy József o. ezds. MN 5. Szanatórium pk.

Dr. Galambos Aladár o. alez. MN 5. Szananatórium pk.h.

Dr. Kálóczy József o. alez. MN 5. Szanatórium pk.gy.h.

Dr. Vittek László o. ezds. MN főanaesthesiológus (05/1988. MN EÜSZF sz. pcs.) [57].

Az 1989-es év is szervezési változásokkal kezdődött: a „Bakony-III” szervezési feladat I. ütemének a végrehajtásával. 
Ennek keretében megszüntették az MN Központi Sorozó Bizottságát, valamint az MN 1. sz. Sorozó Központot (Budapest), állományát és eszközeit a Pest megyei, az MN 2. sz. Sorozó Központot (Veszprém), állományát és eszközeit a Veszprém megyei, az MN 3. sz. sorozó központot (Debrecen), állományát és eszközeit a Hajdú-Bihar megyei Hadkiegészítési és Területvédelmi Parancsnokságok szervezetébe sorolva. Az MN KKK szervezetét „Felsőfokú Orvosi Sorozóbizottság" beállításával módosították [58].

$\mathrm{Az}$ életet ezt követően inkább a várható, nem kisléptékü változások előszele irányította. A szolgálat mindenesetre figyelemmel kísérte az eseményeket, és ugyanúgy, mint az ország, így a Magyar Néphadsereg állománya is nem egyöntetüen és egyforma megítéléssel követte a változásokat. A szakmát tulajdonképpen a kórházrekonstrukció folytatása jelentette, amelynek jegyében 1989-ben a Pszichiátriai osztály ágylétszáma fokozatosan 60-ról 31-re csökkent. Egyidejüleg megalakult a Mentálhigiénés osztály. Az elsöként elkészült és újonnan átadott elöadó teremben a Röntgen osztály megrendezte a Magyar Neuroradiológus Társaság 1. kongresszusát [45].

A már említett változások során olyan kihívásoknak kellett az MN állományának megfelelnie, amelyek teljesen új gondolkodási mód kialakítását is igényelték.

$\mathrm{Az}$ akkori katonai vezetés a hadsereg politikai semlegességének megőrzése, az ország honvédelemmel kapcsolatos gazdasági megterhelésének csökkentése és egyéb megfontolások alapján dolgozta ki és terjesztette a Minisztertanács elé a Honvédelmi Minisztérium szervezetének és vezetési rendjének átalakitására vonatkozó javaslatot, amelyet a Minisztertanács az 1989. november 30-án kelt
344/1989. sz. határozatával jóváhagyott. A szervezeti átalakítás a Honvédelmi Miniszter 00107/89. sz. parancsával lépett érvénybe. A parancs alapján az irányítás és a katonai vezetés szétválasztásra került. Ennek következtében az irányítási - föleg közigazgatási - funkciókat végző Honvédelmi Minisztérium mellett, létrehozták a katonai felsőszintü vezetési feladatokat ellátó Magyar Honvédség Parancsnokságát (MHP). Ezzel teljes egészében leválasztották a katonai szervezeteket a Honvédelmi Minisztériumról, így már 1989. december 1-jétől a 135 fös Honvédelmi Minisztérium közvetlen katonai vezetési jogkörök nélkül (a Magyar Köztársaság 13 minisztériumának egyikeként), közigazgatási közhatalom jogosítványokkal irányította a Magyar Néphadsereget, majd 1990. március 15-től a Magyar Honvédséget (MH) [59].

Az MN, illetve MH első parancsnokává 1989. december 1-től az akkor 50 éves Lörincz Kálmán vezérezredest nevezték ki. Az átalakítások előtti és az utána következő alá- és fölérendelési változásokat az egészségügyi szolgálatot illetően a 7 ., 8 valamint $a$ 9. ábra mutatja.

$\mathrm{Az}$ anyagi és technikai szolgálatok 1987-89 között végrehajtott integrációja - melynek kiteljesedése az MHP megalakulásával következett be - a vezető szervek csökkentését célzó változások az egészségügyi szolgálatnak soha nem látott pozícióvesztést okoztak. A homogenitás elvét figyelembe véve az egészségügyi szolgálat mindenütt az anyagi-technikai szolgálatfönök alárendeltségébe került, az MHP-ság kivételével, ahol az egészségügyi fönökség a hadtáp csoportfönök alárendeltségébe került mindösszesen 5 fövel. Ekkor hozták létre az MN majd MH Egészségügyi Intézetek Főigazgatóságát ( $\mathrm{MN}$ majd $\mathrm{MH}$ EIF), mint az intézeti tagozat elöljáróját. 


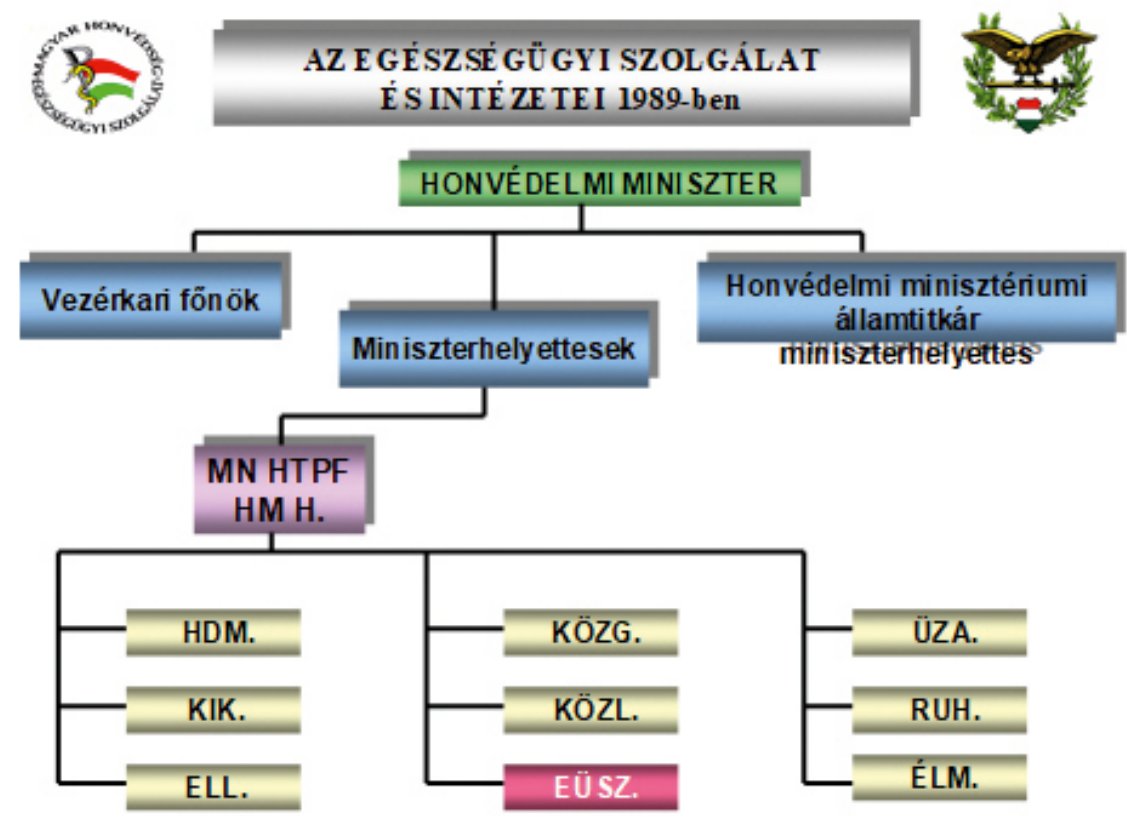

7. ábra. Az MN EÜ.szolgálat alárendeltsége 1989 december 1-ig
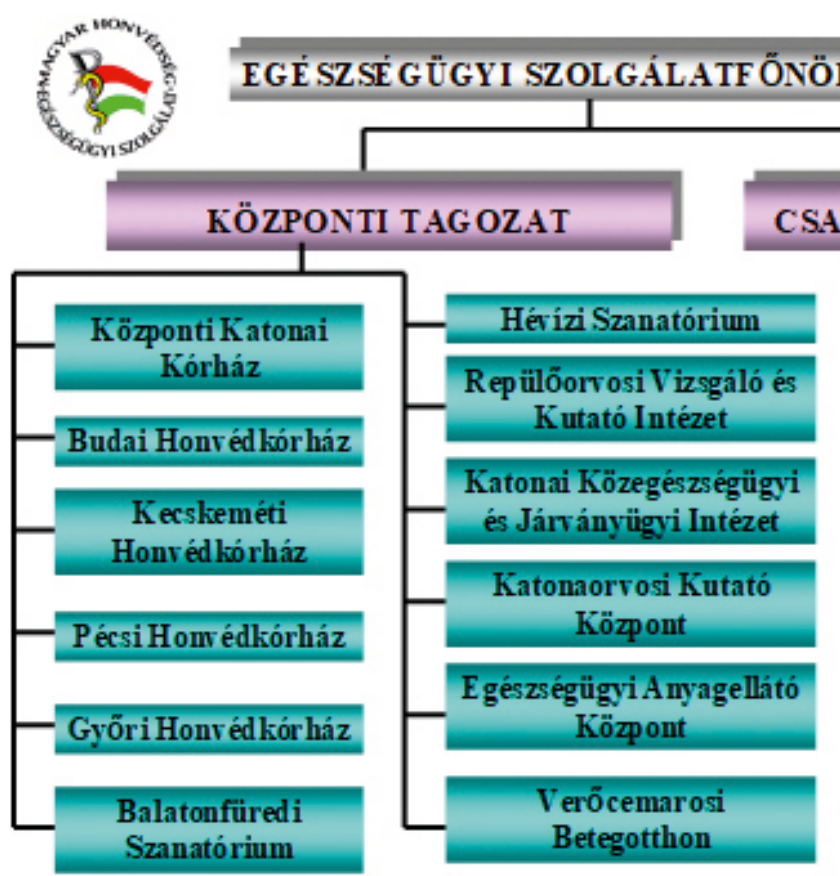

CSAPATTAGOZAT

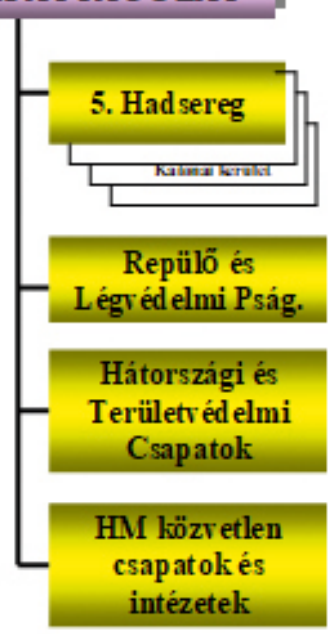

8. ábra. Az MN Eü. szolgálat alárendelt kórházai és intézetei a rendszerváltás idöszakában 

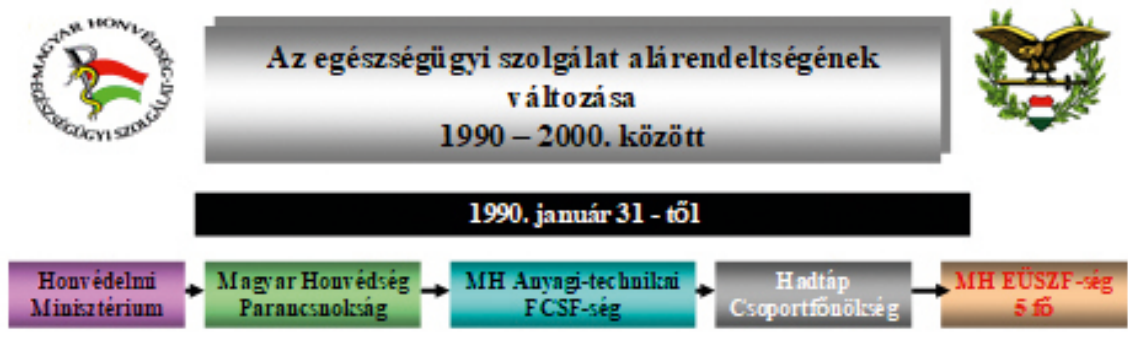

\section{2 február 01 - től}

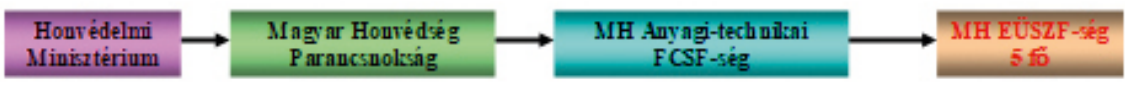

1994. április 01 - tõl

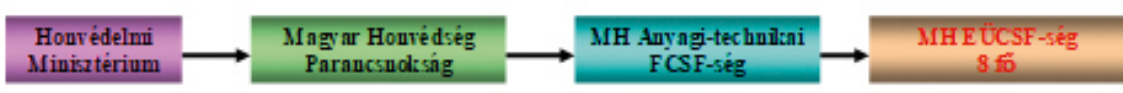

1997. szeptember 01 - töl (2000. október 01-töl)

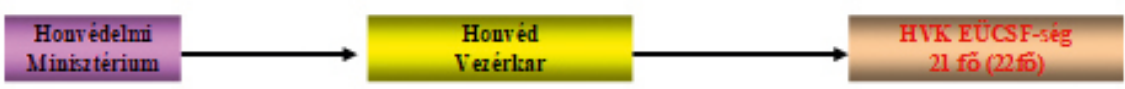

9. ábra. Az MN EÜ.Szolgálat alárendeltsége 1990 január 31-től

( ${ }^{*}$ A 7-9. ábrákat készitette a szerző a Magyar Katona- és Katasztrófa-orvostani Társaság 2000 őszi kongresszusán elhangzott „A MH Egészségügyi Szolgálatának átalakítása az elmúlt évtizedben” címü előadása alapján

Parancsnoka Dr. Villányi Ferenc o. ezds. lett. (EIF alapító határozat MN VKF 00330/1989. sz. int. 1989. augusztus 1.)

A szolgálatfönökség jogosítványa gyakorlatilag a tanácsadás, követelménytámasztás, feltételbiztosítás, ellenőrzés és irányítás funkcióiból állt. Nyilvánvalóan ennek a megmaradt 5 fövel lehetetlen volt eleget tenni.

Az intézeti, illetve a központi tagozat lejtőn való elindulásának kezdőpontja 1989. december volt, mikor is az intézetek megmaradása érdekében az akkor naivan jónak hitt Országos Egészségbiztosító Pénztár (OEP) finanszírozás bevezetésével kapcsolatos szerződést aláírták.

A több hibás pontot is tartalmazó szerződés aláirására nyilvánvalóan a túlélés miatt került sor. Ettől az időponttól kezdve a szolgálat mindennapjait nem a szakmai kihívásoknak, hanem a gazdasági szempontoknak való megfelelésre történő törekvés jellemezte. Fejlesztésről és kiképzésről a folyamatos átszervezések miatt nem lehetett szó.

A csak tartalékosokkal gyakoroltatott háborús intézeti rendszer hatékonyságát az 1989. decemberi romániai forradalom eseményei, illetve az akkor újszerúen jelentkező feladat, nevezetesen a humanitárius segély biztosítása mutatta meg. Az akkor megajánlott sebesültszállító vonat összeállítása és felszerelése rendkívül hosszadalmasan, igen sok problémával valósult meg. Mire a felkészülés közepéig elértünk, addigra az osztrák egészségügyi szolgálat már Romániába küldte vonatát, amelyet azután igénybe sem vettek [2]. 


\section{1. számú melléklet}

Az MN Eü. Szolgálata Központi (intézeti) tagozatának ágystruktúrája, az MN KKK és az 1. sz. KK betegforgalmi mutatóinak alakulása 1980. és 1984. között [Készitette a szerző a 096/1985 sz. MN EüSzF-ségi Előterjesztés (39) fénymásolásával. A Hadtörténelmi Levéltár tulajdona.]

MAGYAR NÉPHADSEREG EGÉSZSÉGÜGYI SZOLGÁLAT

1. sz. melléklet a 096/1985 számhoz FŐNÖKSÉG

\section{AZ MN GYÓGYÍTÓ INTÉZETI ÁGYELLÁTOTTSÁGA 1986-IG}

Ellátandó állomány: 300000 fö

\begin{tabular}{|c|c|c|c|c|c|c|c|c|c|c|}
\hline \multirow[b]{3}{*}{ Fsz. } & \multirow{3}{*}{$\begin{array}{l}\text { SZAKMAI } \\
\text { PROFILOK }\end{array}$} & \multicolumn{9}{|c|}{ ÁGYAK SZÁMA } \\
\hline & & \multicolumn{5}{|c|}{ KÖZPONTI TAGOZAT } & \multicolumn{4}{|c|}{ TERÜLETI TAGOZAT } \\
\hline & & KKK & 1. KK & 4. Szan. & 5. Szan. & $\begin{array}{c}\text { Beteg } \\
\text { otthon }\end{array}$ & 2. KK & 3. KK & 6. KK & $\begin{array}{c}\text { Össze- } \\
\text { sen }\end{array}$ \\
\hline A. & BELGYÓGYÁSZATI & & & & & & & & & \\
\hline 1. & Belgyógyászat & 143 & 70 & - & - & - & 80 & 70 & 80 & 443 \\
\hline 2. & Rheumatológia & - & 6 & 80 & - & - & - & - & - & 86 \\
\hline 3. & Toxikológia & 30 & - & - & - & - & - & - & - & 30 \\
\hline 4. & Tüdőgyógyászat & 40 & - & - & - & - & - & - & - & 40 \\
\hline 5. & Bőrgyógyászat & 60 & - & - & - & - & - & - & - & 60 \\
\hline 6. & Fertőző & 90 & - & - & - & - & - & 20 & - & 110 \\
\hline 7. & Gyermekgyógy. & - & 50 & - & - & - & - & - & - & 50 \\
\hline 8. & Müvese & 5 & - & - & - & - & - & - & - & 5 \\
\hline 9. & Hosszú ápolású & - & - & - & - & 100 & - & - & - & 100 \\
\hline A. & Összesen: & 368 & 126 & 80 & & 100 & 80 & 90 & 80 & 924 \\
\hline B. & $\underline{\text { IDEG - ELME }}$ & & & & & & & & & \\
\hline 10. & Ideggyógyászat & 50 & 30 & - & - & - & 30 & 30 & 50 & 190 \\
\hline 11. & Psychiátria & 50 & 20 & - & - & - & 20 & 10 & 30 & 130 \\
\hline B. & Összesen: & 100 & 50 & - & - & - & 50 & 40 & 80 & 320 \\
\hline C. & SEBÉSZET & & & & & & & & & \\
\hline 12. & Általános & 124 & 60 & - & - & - & 40 & 45 & 40 & 309 \\
\hline 13. & Baleseti & 90 & - & - & - & - & 40 & 55 & 40 & 225 \\
\hline 14. & Ideg & 40 & - & - & - & - & - & - & 40 & 80 \\
\hline 15. & Plasztikai & 50 & - & - & - & - & - & - & - & 50 \\
\hline 16. & Száj & 20 & - & - & - & - & - & - & - & 20 \\
\hline 17. & Égési & 18 & - & - & - & - & - & 20 & 20 & 58 \\
\hline 18. & Urológia & 40 & - & - & - & - & - & - & - & 40 \\
\hline 19. & Szül.-nőgyógy. & - & 60 & - & - & - & - & - & - & 60 \\
\hline 20. & Fül-Orr-Gége & 50 & 20 & - & - & - & 20 & 30 & - & 120 \\
\hline 21. & Szemészet & 55 & - & - & - & - & 20 & - & - & 75 \\
\hline C. & Összesen: & 487 & 140 & - & - & - & 120 & 150 & 140 & 1037 \\
\hline
\end{tabular}




\begin{tabular}{|c|c|c|c|c|c|c|c|c|c|c|}
\hline \multirow[b]{3}{*}{ Fsz. } & \multirow{3}{*}{$\begin{array}{l}\text { SZAKMAI } \\
\text { PROFILOK }\end{array}$} & \multicolumn{9}{|c|}{ ÁGYAK SZÁMA } \\
\hline & & \multicolumn{5}{|c|}{ KÖZPONTI TAGOZAT } & \multicolumn{4}{|c|}{ TERÜLETI TAGOZAT } \\
\hline & & KKK & 1. KK & 4. Szan. & 5. Szan. & $\begin{array}{c}\text { Beteg } \\
\text { otthon }\end{array}$ & 2. KK & 3. KK & 6. KK & $\begin{array}{c}\text { Össze- } \\
\text { sen }\end{array}$ \\
\hline D. & INTENZÍV & & & & & & & & & \\
\hline 22. & Központi Int. & - & 6 & - & - & - & 5 & 7 & 5 & 23 \\
\hline 23. & Örző & 22 & 6 & - & - & - & 6 & - & 10 & 44 \\
\hline \multirow[t]{6}{*}{ D. } & Összesen: & 22 & 12 & - & - & - & 11 & 7 & 15 & 67 \\
\hline & $\underline{\text { REHABILITÁCIÓ }}$ & & & & & & & & & \\
\hline & Általános & - & - & 60 & 50 & - & - & - & - & 110 \\
\hline & Mozgásszervi & - & - & 60 & - & - & - & - & - & 60 \\
\hline & Szív-érrendszeri & - & - & - & 50 & - & - & - & - & 50 \\
\hline & Összesen: & - & - & 120 & 100 & - & - & - & - & 220 \\
\hline \multicolumn{2}{|c|}{ MINDÖSSZESEN: } & 977 & 328 & 200 & 100 & 100 & 261 & 287 & 315 & 2568 \\
\hline
\end{tabular}

\section{MAGYAR NÉPHADSEREG}

EGÉSZSÉGÜGYI SZOLGÁLAT

FÖNÖKSÉG

\section{Az MN KKK Betegforgalmi statisztikája} (1980-1984)

\begin{tabular}{|c|c|c|c|c|c|c|c|c|c|c|c|c|c|}
\hline \multirow{3}{*}{ Év } & \multicolumn{8}{|c|}{ Igényjogosult } & \multicolumn{3}{|c|}{ Nem igényjogosult } & \multicolumn{2}{|c|}{ Mindösszesen } \\
\hline & \multicolumn{2}{|c|}{ Ht. tsz. } & \multicolumn{2}{|c|}{ Sorállomány } & \multicolumn{2}{|c|}{ Kpa. Рa. } & \multicolumn{2}{|c|}{ Egyéb $^{*}$} & \multicolumn{2}{|c|}{ Összesen } & \multirow[b]{2}{*}{ Bp. } & \multirow{2}{*}{ Össz. } & \multirow[t]{2}{*}{ D } \\
\hline & Össz. & Bp. & Össz. & Bp. & Össz. & Bp. & Össz. & Bp. & Fö & $\%$ & & & \\
\hline 1980. & 2214 & 726 & 7829 & 2502 & 2690 & 1824 & 720 & 600 & 5316 & 28,3 & 4278 & 18769 & 9930 \\
\hline 1981. & 2093 & 810 & 7804 & 2766 & 2575 & 1860 & 760 & 742 & 5425 & 29,1 & 4458 & 18657 & 10636 \\
\hline 1982. & 2018 & 1026 & 8070 & 2712 & 2386 & 1974 & 724 & 695 & 5707 & 30,2 & 4188 & 18905 & 10595 \\
\hline 1983. & 1764 & 570 & 6837 & 2262 & 2355 & 1938 & 753 & 739 & 5733 & 32,8 & 3834 & 17442 & 9343 \\
\hline 1984. & 1512 & 744 & 6600 & 2556 & 3414 & 2208 & 1341 & 1265 & 5806 & 31,1 & 3396 & 18675 & 10169 \\
\hline
\end{tabular}

* Megjegyzés: az egyéb kategóriába tartoznak a családtagok, a pártveteránok, a más fegyveres testületek tagjai, valamint a szerződés alapján ellátottak és a külföldi betegek.

MAGYAR NÉPHADSEREG EGÉSZSÉGÜGYI SZOLGÁLAT FÖNÖKSÉG

MN 1. KK Betegforgalmi statisztikája (1980-1984)

\begin{tabular}{|c|c|c|c|c|c|c|c|c|c|c|c|c|c|}
\hline \multirow{3}{*}{ Év } & \multicolumn{8}{|c|}{ Igényjogosult } & \multicolumn{3}{|c|}{ Nem igényjogosult } & \multicolumn{2}{|c|}{ Mindösszesen } \\
\hline & \multicolumn{2}{|c|}{ Ht. tsz. } & \multicolumn{2}{|c|}{ Sorállomány } & \multicolumn{2}{|c|}{ Kpa. Рa. } & \multicolumn{2}{|c|}{ Egyéb ${ }^{*}$} & \multicolumn{2}{|c|}{ Összesen } & \multirow[b]{2}{*}{ Bp. } & \multirow{2}{*}{ Össz. } & \multirow{2}{*}{ Bp. } \\
\hline & Össz. & Bp. & Össz. & Bp. & Össz. & Bp. & Össz. & Bp. & Fö & $\%$ & & & \\
\hline 1980. & 741 & 528 & 96 & 36 & 2683 & 2568 & 827 & 790 & 1704 & 28,1 & 954 & 6051 & 4876 \\
\hline 1981. & 660 & 564 & 73 & 30 & 2456 & 2314 & 1054 & 952 & 1628 & 27,7 & 912 & 5871 & 4772 \\
\hline 1982. & 600 & 546 & 21 & 18 & 2444 & 2358 & 948 & 875 & 1960 & 32,8 & 1074 & 5973 & 4871 \\
\hline 1983. & 601 & 498 & 43 & 12 & 2190 & 2094 & 1084 & 962 & 2019 & 34,0 & 996 & 5937 & 4562 \\
\hline 1984. & 360 & 306 & 25 & 11 & 1038 & 852 & 745 & 734 & 306 & 12,4 & 306 & 2474 & 2209 \\
\hline
\end{tabular}

* Megjegyzés: az egyéb kategóriába tartoznak a családtagok, a pártveteránok, a más fegyveres testületek tagjai, valamint a szerződés alapján ellátottak és a külföldi betegek. 
MAGYAR NÉPHADSEREG

EGÉSZSÉGÜGYI SZOLGÁLAT

FÖNÖKSÉG

Az MN KKK járóbetegforgalmának adatai

(1980-1984)

\begin{tabular}{|c|c|c|c|c|c|c|c|}
\hline \multirow{2}{*}{ Év } & \multicolumn{4}{|c|}{ Igényjogosult } & \multicolumn{2}{|c|}{ Nem igényjogosult } & \multirow{2}{*}{$\begin{array}{c}\text { Mindössze- } \\
\text { sen }\end{array}$} \\
\hline & Ht. tsz. & Sorállomány & Kpa. Рa. & Egyéb & Fö & $\%$ & \\
\hline 1980. & 35540 & 56865 & 23909 & 18093 & 27140 & 16,8 & 161547 \\
\hline 1981. & 28743 & 59993 & 23290 & 15035 & 20341 & 13,8 & 147402 \\
\hline 1982. & 27895 & 56373 & 21793 & 17725 & 21503 & 14,8 & 145289 \\
\hline 1983. & 35638 & 62366 & 24375 & 22190 & 23534 & 14,0 & 168103 \\
\hline 1984. & 36008 & 70588 & 24956 & 27095 & 19608 & 11,0 & 178255 \\
\hline
\end{tabular}

MAGYAR NÉPHADSEREG EGÉSZSÉGÜGYI SZOLGÁLAT

FÖNÖKSÉG

Az MN 1. KK járóbetegforgalmának adatai (1980-1984)

\begin{tabular}{|c|c|c|c|c|c|c|c|}
\hline \multirow{2}{*}{ Év } & \multicolumn{4}{|c|}{ Igényjogosult } & \multicolumn{2}{|c|}{ Nem igényjogosult } & \multirow{2}{*}{$\begin{array}{c}\text { Mindössze- } \\
\text { sen }\end{array}$} \\
\hline & Ht. tsz. & Sorállomány & Kpa.Pa. & Egyéb & Fő & $\%$ & \\
\hline 1980. & 22413 & 695 & 17491 & 78671 & 26415 & 18,1 & 145685 \\
\hline 1981. & 21998 & 1389 & 24340 & 74274 & 23105 & 15,9 & 145106 \\
\hline 1982. & 21913 & 1384 & 22768 & 72334 & 22254 & 15,8 & 140653 \\
\hline 1983. & 18017 & 2346 & 19459 & 73955 & 22032 & 16,2 & 135809 \\
\hline 1984. & 7215 & 145 & 7236 & 19455 & 8312 & 19,6 & 42363 \\
\hline
\end{tabular}

MAGYAR NÉPHADSEREG

EGÉSZSÉGÜGYI SZOLGÁLAT

FÖNÖKSÉG

\section{Az MN-ben EÜ. ellátásra jogosultak katonai kórházi utaltság szerinti megoszlása}

\begin{tabular}{|l|c|}
\hline \multicolumn{1}{|c|}{ Kórházak megnevezése } & Ellátásra utaltak száma (fö) \\
\hline MN Központi Katonai Kórház & 150000 \\
\hline MN 1. Katonai Kórház & 40000 \\
\hline MN 2. Katonai Kórház & 55000 \\
\hline MN 3. Katonai Kórház & 40000 \\
\hline MN 6. Katonai Kórház & 23000 \\
\hline Összesen: & 308000 \\
\hline
\end{tabular}




\section{2. számú melléklet}

Az MN személyi állományának szürővizsgálati, megbetegedési és betegforgalmi adatai 1980-1985. között

[Készitette a szerző a 00179/30/1986 sz. MN EüSzF-ségi „Előterjesztés” (51) fénymásolásával. A Hadtörténelmi Levéltár tulajdona.]

Az MN HT (hivatásos) állomány éves szürővizsgálati adatai EÜ. minősítés szerint (MN szintü összesítés)

\begin{tabular}{|c|c|c|c|c|c|c|c|}
\hline Fsz. & EÜ. minősítés & & 1980 & 1981 & 1982 & 1984 & 1985 \\
\hline \multirow[t]{2}{*}{1.} & \multirow{2}{*}{ Gyakorlatilag egészséges } & fö & 12870 & 13426 & 12457 & 12355 & 12678 \\
\hline & & $\%$ & 63,5 & 61,5 & 69,2 & 63,1 & 62,6 \\
\hline \multirow[t]{2}{*}{2.} & \multirow{2}{*}{ Gondozásra szorui } & fó & 4667 & 5358 & 4227 & 4551 & 4674 \\
\hline & & $\%$ & 23,0 & 24,5 & 21,7 & 23,3 & 23,1 \\
\hline \multicolumn{8}{|c|}{ Ebből: } \\
\hline & \multirow{2}{*}{ Gyógyüdülés javasolt } & fö & 1436 & 1837 & 900 & 1102 & 1341 \\
\hline & & $\%$ & 7,1 & 8,4 & 4,6 & 5,6 & 6,6 \\
\hline & \multirow{2}{*}{ Szanatórium javasolt } & fö & 355 & 485 & 454 & 495 & 302 \\
\hline & & $\%$ & 1,7 & 2,2 & 2,3 & 2,5 & 2,5 \\
\hline \multirow{2}{*}{$1-2$. } & \multirow{2}{*}{ Szolgálatképes } & fö & 17537 & 18784 & 16684 & 16906 & 17352 \\
\hline & & $\%$ & 86,5 & 86,0 & 85,9 & 86,4 & 85,7 \\
\hline \multirow{2}{*}{3.} & \multirow{2}{*}{ Szakorvosi kezelés javasolt } & fö & 2028 & 2362 & 2068 & 1950 & 2176 \\
\hline & & $\%$ & 10,0 & 10,8 & 10,6 & 10,0 & 10,7 \\
\hline \multirow{2}{*}{4.} & \multirow{2}{*}{ Kórházi kezelés javasolt } & fó & 482 & 468 & 466 & 492 & 508 \\
\hline & & $\%$ & 2,4 & 2,1 & 2,4 & 2,5 & 2,5 \\
\hline \multirow{2}{*}{5.} & \multirow{2}{*}{ FÜV. javasolt } & fö & 213 & 251 & 217 & 221 & 223 \\
\hline & & $\%$ & 1,1 & 1,1 & 1,1 & 1,1 & 1,1 \\
\hline
\end{tabular}

\section{Alkalmatlanságot okozó főbb betegségek az MN sorállományánál sorozáskor és a katonai szolgálat során}

\begin{tabular}{|c|c|c|c|c|c|c|c|c|}
\hline \multirow{3}{*}{ ÉV } & \multicolumn{9}{|c|}{ SOROZÁSKOR } & \multicolumn{5}{c|}{ KATONAI SZOLGÁLAT ALATT } \\
\cline { 2 - 10 } & \multicolumn{9}{|c|}{ Az alkalmatlanságot okozó fóbb betegségcsoportok (\%) } \\
\cline { 2 - 10 } & Ideg & Mozgás & Emésztés & Szív & Ideg & Mozgás & Emésztés & Szív \\
\hline 1971 & 15,0 & 11,8 & 10,1 & 22,5 & 22,2 & 25,2 & 14,2 & 7,2 \\
\hline 1978 & 30,3 & 15,0 & 5,1 & 12,6 & 33,9 & 27,7 & 13,3 & 3,1 \\
\hline 1980 & 35,5 & 3,8 & 3,8 & 11,4 & 31,9 & 24,2 & 16,6 & 3,3 \\
\hline 1981 & 38,3 & 12,9 & 1,9 & 12,9 & 35,8 & 21,5 & 16,0 & 2,9 \\
\hline 1982 & 29,0 & 10,4 & 1,7 & 10,1 & 35,4 & 24,6 & 12,7 & 3,9 \\
\hline 1983 & 32,7 & 11,2 & 1,5 & 11,1 & 36,4 & 27,0 & 12,4 & 3,3 \\
\hline 1984 & 30,0 & 11,3 & 1,5 & 11,7 & 39,4 & 22,9 & 13,3 & 3,3 \\
\hline 1985 & 30,9 & 11,2 & 1,3 & 12,4 & 38,4 & 28,9 & 10,1 & 3,9 \\
\hline
\end{tabular}


A HT (hivatásos), TSz. (továbbszolgáló) állományúak körében az alapellátásban leggyakrabban előforduló betegségcsoportok (100 megjelent betegre számolva)

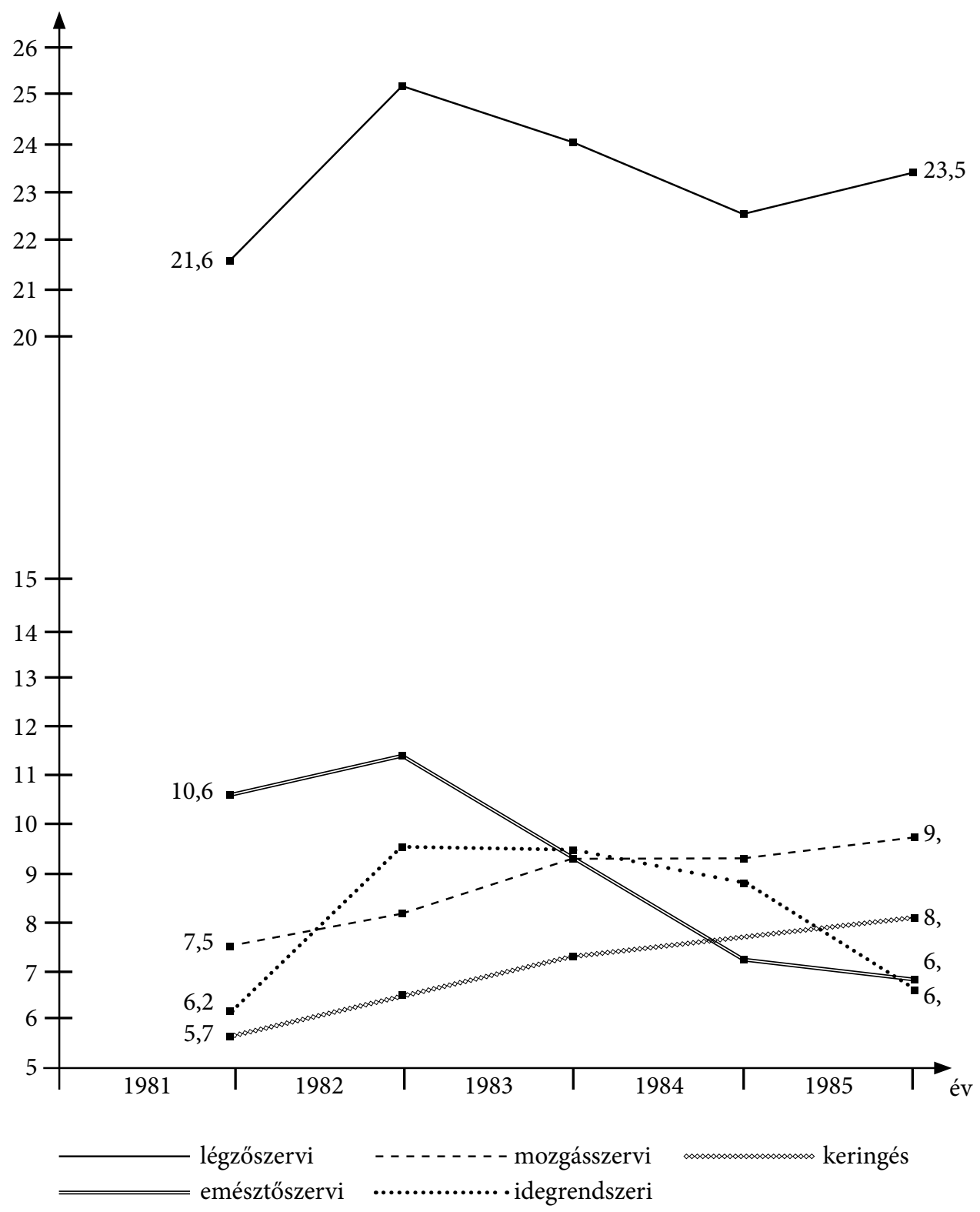




\section{Az MN HT (hivatásos) állományából gyakorlatilag egészségesek aránya} az éves szürővizsgálatok alapján

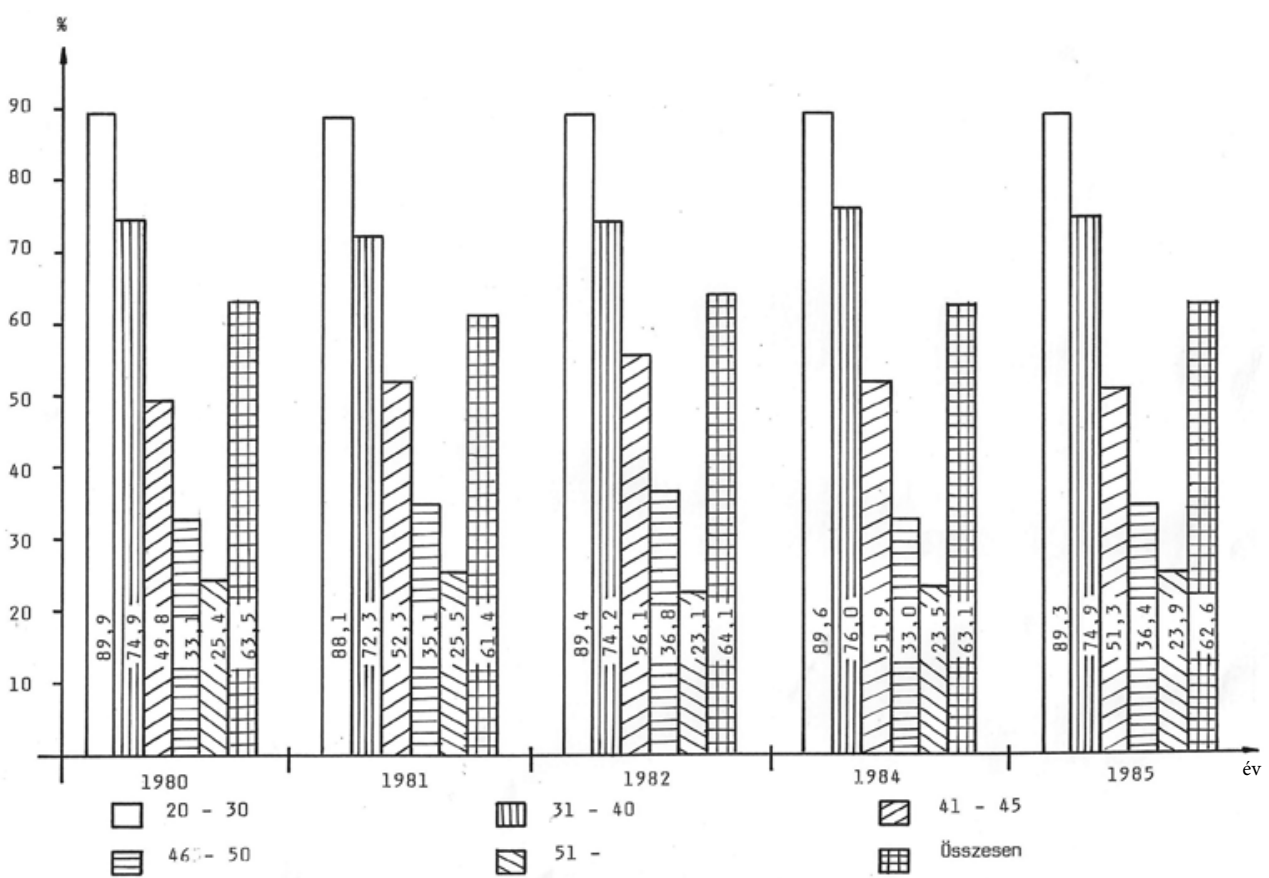

Az MN kórházakban ápolt betegek számának alakulása állománycsoportok szerinti bontásban (1981-1985)

\begin{tabular}{|c|c|c|c|c|c|c|c|c|c|c|}
\hline & \multicolumn{2}{|c|}{1981} & \multicolumn{2}{|c|}{1982} & \multicolumn{2}{|c|}{1983} & \multicolumn{2}{|c|}{1984} & \multicolumn{2}{|c|}{1985} \\
\hline & fö & $\%$ & fö & $\%$ & fö & $\%$ & fö & $\%$ & fö & $\%$ \\
\hline $\begin{array}{l}\text { Hivatalos állomány } \\
\text { tsz. állomány }\end{array}$ & 3360 & 9,8 & 3692 & 10,7 & 3367 & 10,0 & 2990 & 9,6 & 2951 & 8,5 \\
\hline Sorállomány & 11839 & 34,7 & 11519 & 33,3 & 10572 & 31,4 & 10545 & 33,6 & 10972 & 31,8 \\
\hline $\begin{array}{l}\text { Kinevezett polgári-, } \\
\text { polgári alk. }\end{array}$ & 2081 & 6,1 & 2882 & 8,3 & 2075 & 6,1 & 1550 & 4,9 & 1656 & 4,7 \\
\hline Egyéb jogosult & 6178 & 18,1 & 5918 & 17,1 & 5604 & 16,6 & 5927 & 19,1 & 5812 & 16,8 \\
\hline Igényjogosult összesen & 23458 & 68,7 & 24011 & 69,4 & 21618 & 64,1 & 21012 & 67,2 & 21391 & 61,9 \\
\hline Nem igényjogosult & 10558 & 31,3 & 10482 & 30,6 & 11945 & 35,9 & 10102 & 32,8 & 13149 & 38,1 \\
\hline Összesen & 34016 & 100,0 & 34493 & 100,0 & 33563 & 100,0 & 31114 & 100,0 & 34540 & 100,0 \\
\hline
\end{tabular}


A sorállományúak körében az alapellátásban leggyakrabban elöforduló betegségcsoportok (100 megjelent betegre számolva)
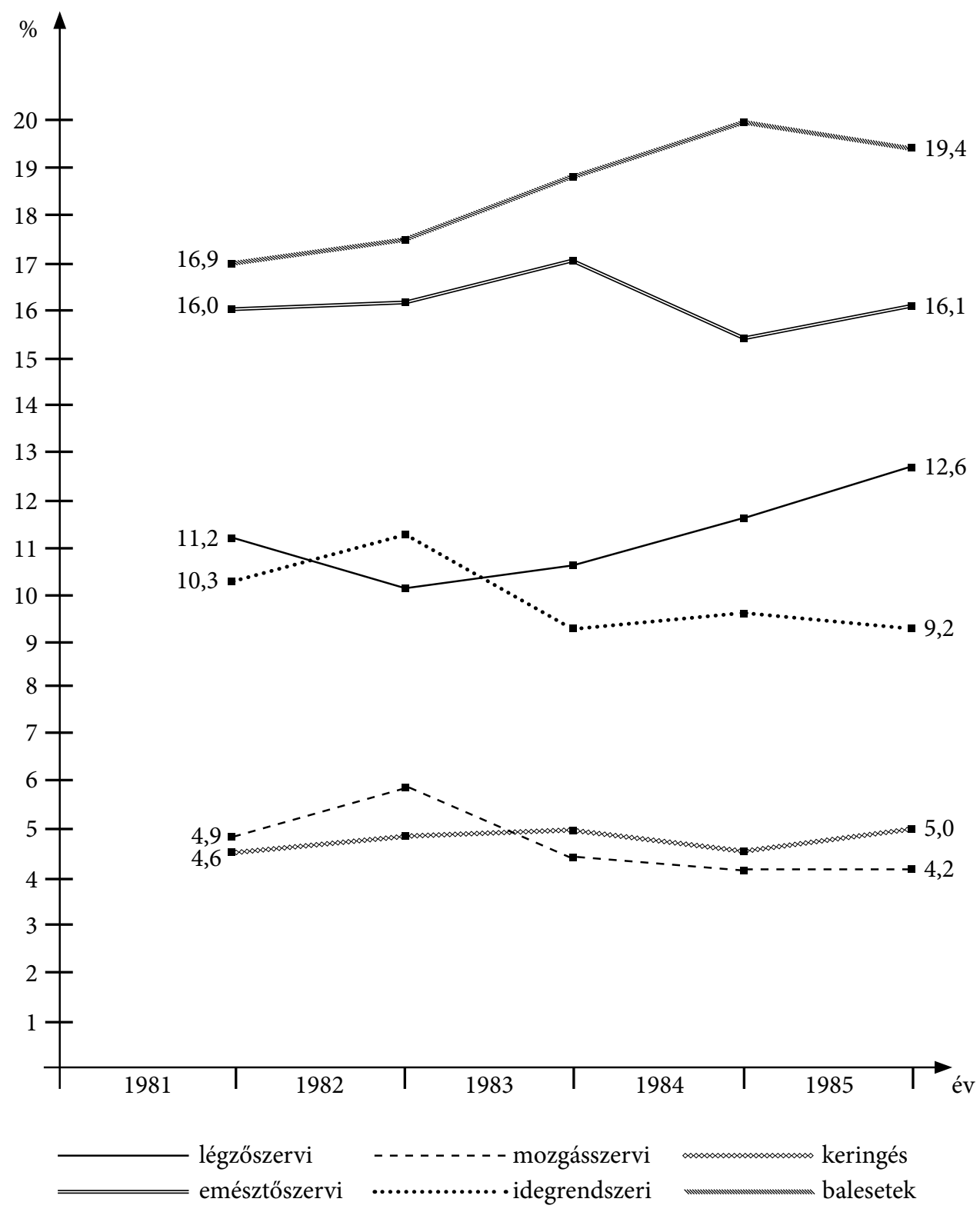
A sorállományúak körében az alapellátásban leggyakrabban előforduló betegségcsoportok (100 megjelent betegre számolva)
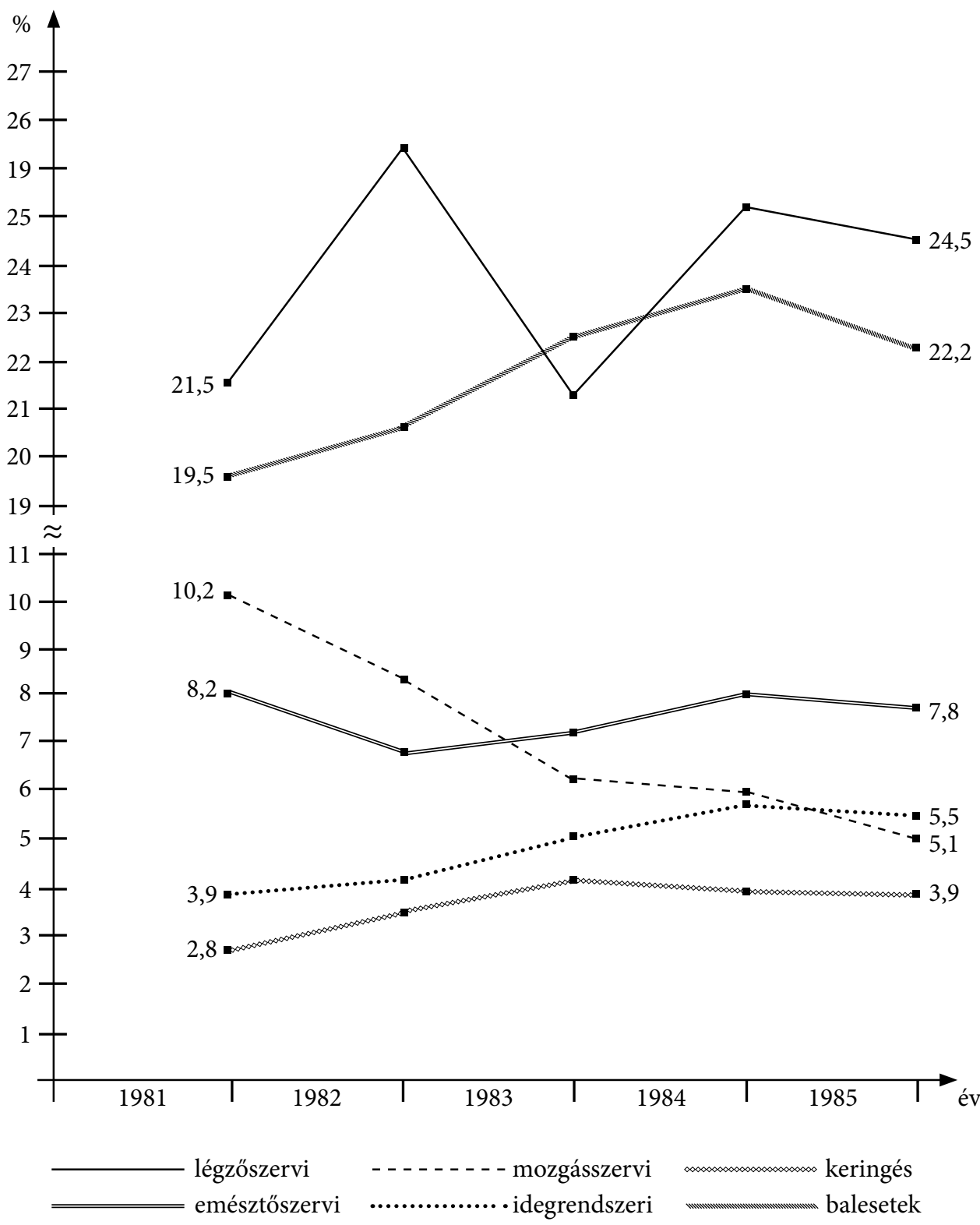


\section{A sorozások és a FÜV alapvető mutatói a sorkötelesekre vonatkozóan}

\begin{tabular}{|c|c|c|c|c|c|c|c|c|c|c|c|c|}
\hline \multirow{3}{*}{ Év } & \multicolumn{8}{|c|}{ Sorozáskor minősített } & & \multirow{2}{*}{\multicolumn{3}{|c|}{$\begin{array}{c}\text { Szolgálat alatt minö- } \\
\text { sített }\end{array}$}} \\
\hline & \multirow{2}{*}{$\begin{array}{c}\text { Behívha- } \\
\text { tó (\%) }\end{array}$} & \multicolumn{3}{|c|}{ Korlátozással alkalmas (\%) } & \multirow{2}{*}{$\begin{array}{c}\text { Alkal- } \\
\text { matlan } \\
(\%)\end{array}$} & \multicolumn{4}{|c|}{ Az alkalmatlanok \% megoszlás szerint } & & & \\
\hline & & B & $\mathrm{C}$ & $\mathrm{D}$ & & Szív & Mozgás & Emésztö & Ideg & K. A. & AN. & $\begin{array}{c}1971 . \\
\text { \%-ában }\end{array}$ \\
\hline 71 & 82,4 & - & 8,2 & - & 17,6 & 22,5 & 11,8 & 10,1 & 15,0 & 400 & 5476 & 100,0 \\
\hline 78 & 90,3 & 2,4 & 2,7 & 0,5 & 9,7 & 12,6 & 15,0 & 5,1 & 30,3 & 562 & 3713 & 67,8 \\
\hline 80 & 88,6 & 2,2 & 2,9 & 0,6 & 11,4 & 11,4 & 3,8 & 3,8 & 35,5 & 733 & 2337 & 42,7 \\
\hline 81 & 90,6 & 2,6 & 4,7 & 0,3 & 9,4 & 12,9 & 12,9 & 1,9 & 28,3 & 901 & 2553 & 46,6 \\
\hline 82 & 88,4 & 2,1 & 2,4 & 0,5 & 11,6 & 10,1 & 10,4 & 1,7 & 29,0 & 894 & 2795 & 51,0 \\
\hline 83 & 89,0 & 2,4 & 2,7 & 0,6 & 11,0 & 11,1 & 11,2 & 1,5 & 32,7 & 956 & 2820 & 51,5 \\
\hline 84 & 88,3 & 2,3 & 2,9 & 0,4 & 11,7 & 11,7 & 11,3 & 1,5 & 30,0 & 953 & 3254 & 59,4 \\
\hline 85 & 88,5 & 2,5 & 3,1 & 0,5 & 11,5 & 12,4 & 11,2 & 1,3 & 30,9 & 1238 & 3192 & 58,3 \\
\hline
\end{tabular}

\section{Az MN kórházakban ápolt betegek száma (összesen) kórházak szerinti bontásban}

\begin{tabular}{|c|c|c|c|c|c|c|c|c|c|c|}
\hline & \multicolumn{2}{|c|}{1981} & \multicolumn{2}{|c|}{1982} & \multicolumn{2}{|c|}{1983} & \multicolumn{2}{|c|}{1984} & \multicolumn{2}{|c|}{1985} \\
\hline & fó & $\%$ & fö & $\%$ & fö & $\%$ & fö & $\%$ & fö & $\%$ \\
\hline $\begin{array}{l}\text { Központi Katonai } \\
\text { Kórház }\end{array}$ & 18657 & 54,9 & 18905 & 54,8 & 17442 & 52,1 & 17227 & 55,5 & 17616 & 50,9 \\
\hline 1. Katonai Kórház & 5871 & 17,3 & 5973 & 17,3 & 5937 & 17,7 & 2655 & 8,5 & 2857 & 8,3 \\
\hline 2. Katonai Kórház & 5100 & 14,9 & 5471 & 15,8 & 5864 & 17,4 & 5773 & 18,6 & 5275 & 15,3 \\
\hline 3. Katonai Kórház & 4396 & 12,9 & 4144 & 12,1 & 4320 & 12,8 & 4505 & 14,5 & 4794 & 13,9 \\
\hline 6. Katonai Kórház & - & - & - & - & - & - & $863^{*}$ & 2,9 & 3998 & 11,6 \\
\hline Összesen & 34024 & 100,0 & 34493 & 100,0 & 33563 & 100,0 & 31023 & 100,0 & 34540 & 100,0 \\
\hline
\end{tabular}

* (1984.09.03-12.31.)

\section{Irodalom}

[1] 1848-2004. A hazáért. A Magyar Honvédség múltja és jelene. (Szaktudás Kiadó Ház Zrt. Budapest, 2006.) 398. o.

[2] Svéd L.: A Magyar Honvédség egészségügyi biztosítása elvének és gyakorlatának változásai, sajátosságai, különös tekintettel a haderő átalakítására, a NATO-ba történő integrálásra, a különböző fegyveres konfliktusok, valamint a békefenntartó, béketeremtő és támogató tevékenységre. $\mathrm{PhD}$ értekezés, $\mathrm{Bu}$ dapest, 2003.

[3] Az MN katona-egészségügyi szolgálata történetének összefoglaló adatai 1956-1980. között. Nyt.sz: 0649/20/1984. KGY.MN. Története $11 / \mathrm{b} .25 \mathrm{~b}$

[4] Remes P., Grósz A., Szabó J.: A magyar repülőés ürorvostan története. 2013, Zrínyi Kiadó
[5] MN történeti interjúk:

Téma: Katona-egészségügy, katonai orvoslás 2003. 05. 19., 06. 05. műv.n.sz. 21/2015.

Dr. Hideg János, Dr. Manninger Jenő, Dr. Vámos László, Dr. Farkas József orvos vezérőrnagyok.

[6] MN EÜSZF 0091/1980. számú intézkedése (1980. szeptember 01.), a tartalékos hadkötelesek kiképzésére, az intézetek és csapatok összekovácsolására és háborús időszakban a harckiképzés megszervezésére és végrehajtására. Hadtörténelmi Levéltár (HL) 1107. doboz (d)/1690 őrzési egység (öe).

[7] MN Hadtáp Főnökség 1981. évi titkos sorozatos rendelkezései HL 1109 d./1696 öe.

[8] MN Hadtáp Főnökség 1982. évi titkos sorszámú rendelkezései HL 1111 d./1701 öe.

[9] 00198/1982. az MN hadrendjének rendszeresített állománya, 1982. augusztus 01., 
MN VK Szervezési Csoportfőnökség, HL 194/0816 HL Az MN rendszeresített és meglévő személyi állomány 1981-1982-19841986-ig HL 472 d./729 öe

[11] MN VK Hadműveleti Főcsoportfönökség miniszteri szemle anyaga, 1984. és a „Kunság-83, Bazalt-83” hadgyakorlatok anyagai, MN V. Hadsereg 002061/1983. sz. gyakorlat értékelés, 31. és 54. old. HL 364 d./588 öe.

[17] MN Hadtáp Főnökség (eü.szolg.) titkos sorszámú rendelkezések, 1983. HL 1114 d./1707 öe.

[19] Jelentés az MN hadtáp helyzetéről 1988. HL 1133 d./1741 öe.

[20] MN HF nyílt sorszámos rendelkezések 1980. HL 1108 d./1692 öe.

[21] MN HF, MN EÜSZF-ség 1980. évi nyílt sorszámos rendelkezések. HL 1108 d./1693 öe.

[22] Htp/16. Csapathadtáp Szakutasítás az állandó harckészültség időszakára. IV. rész. A személyi állomány egészségügyi ellátása.

[23] 026/65/1980. 213/K áll.tbl. (B) MN VK Szervezési Főcsoportfőnökség. HL 400 d./645 öe. 1980.

[24] Magyarország hadtörténete 2. Szerkesztő Tóth Sándor, 1985. Zrínyi Katonai Kiadó 572-574. o.

[25] MN HTPF-ség, EüSZF 1981 évi nyílt sorszámos rendelkezések 1981.HL 1110d./1698 öe.

[26] MN HF nyílt sorszámú rendelkezések 1981. HL 1110 d./1699öe,

[27] MN Hadtápfönökség nyílt sorszámú rendelkezései, MN EüSZF-ség 1982 évi sorszámos rendelkezései HL 1112 d./1703 öe.

[28] MN VK Hadmüveleti csoportfőnökség „Duna-82”, „Duna-83” hadgyakorlat anyagai HL 319 d./540 öe.

[29] MN Hadtápfönökség Egészségügyi szolgálatfőnökség 1983 évi nyílt sorszámos rendelkezések HL 1115 d./1708 öe.

[30] HM Titkárság HM KT ülés anyagai 1983-84. HL 83d./144 öe.

[31] MNHF-ség Intézkedések a MÁTRA-III hadtápbiztosítására 1983 nytsz.0023/21/1983 HL 1108 d./1694 öe.

[32] MN HTPF-ség, MN EüSZF-ség titkos sorszámos rendelkezések 1984 HL 1117d./1711 öe.
[33] MN Eü. szolgálatfönökség nyílt sorszámos rendelkezések 1984 HL 1119d./1715 öe.

[34] HM Titkárság 1984 évi Titkos HM sorszámos rendelkezések HL 7 d./14 öe.

[35] Éves beszámoló jelentések 1970-es-1980-as évek. MN VK Szervezési csportfőnökség HL 638 d./927 öe.

[36] A Hátországi Egészségügyi Alakulatok Parancsnokságának rendeltetése és feladatai háborúban (Dr. Törö István o.alez.) Hadtápbiztosítás, 1985. 2. sz. 107. o. XVIII. évfolyam.

[37] Az MN csapatai és intézetei háborús tevékenysége egészségügyi biztosításának rendje (Dr. Villányi Ferenc o.alez, Dr. László Imre o.alez., Dr. Horváth István o.ezds.) Hadtápbiztosítás, 1985 2. sz. 84. o. XVIII. évfolyam.

[38] Éves beszámoló jelentések. 1970-es-80-as évek. MNVK Szervezési csoportfőnökség. Oláh István vez.ezds. Honvédelmi Miniszter előadói beszéde. Nytsz.0015/27/1985 HDM. HL 638 d./927 öe.

[39] HM Titkárság HM KT ülésének anyagai 1985 HL 10d./31 öe.

[40] MN Hadtápfőnökség (MNHF, EüSZF, KSzF, ÉSzF, ÜSzF) 1985 évi nyílt sorszámos rendelkezések HL 1123d./1722 öe.

[41] A csapat egészségügyi szolgálat helye és szerepe a katona egészségügyi ellátásban. (Dr. Svéd László o.alez.) Hadtápbiztosítás, 1985. 2. sz. 100-102 o. XVIII évf.

[42] MNHF Titkos sorszámos rendelkezések 1985 évi HL 1122 d./1720 öe.

[43] HM Titkárság Vegyes Iratok 1982-85.014/ 1985 sz. jegyzőkönyv HL 11 d./34 öe.

[44] Az „ORION-85” egészségügyi rendszer gyakorlat fóbb tapasztalatai (Dr.Villányi Ferenc o. alez.) Hadtápbiztosítás, 1985 3. sz. 48-49. és 55. o. XVIII évf.

[45-46] Honvédkórház Kórháztörténet 18991999 Jubileumi Emlékkönyv. MN Védelem Egészségügyi Intézet Tudományos könyvtár

[47] MN Hadtápfőnökség, Munkaterv 1986. Bakony-I Hadtápbiztosítás, Hadtáp helyzetjelentés 1986. HL 1131 d./1733 öe.

[48] MN Hadtápfönökség MNHF 1986 évi Titkos sorszámos rendelkezések HL 1126 d./1726 öe. 
[49] MN HTP főnökség nyílt sorszámos rendelkezések 1986 HL 1127 d./1728 öe.

[50] MN http főnökség, MN EüSZF 1986 évi nyílt sorszámos rendelkezések HL 1128 d./1729 öe.

[51] Előterjesztés a Katonai Tanácshoz az MN személyi állományának béke egészségügyi ellátásának helyzetéről és fejlesztésének főbb irányairól HL 1131 d./1734 öe.

[52] MNHF-ség, MN EüSzF-ség 1986 évi Titkos sorszámos rendelkezések HL 1127 d./1727 öe.

[53] Tájékoztató az MN hadtáp vezető állománya részére megtartott a gazdasági-társadalmi kibontakozás feladatait meghatározó értekezletről. 1987. december 9.8-13.old. HL 1133 d./1739 öe.

[54] MN HTP-főnökség személyügyi titkos sorszámú rendelkezések 1988 HL 1132 d./1737 öe.

[55] MN HTP-fönökség 1988 évi munkaterve.053/1988 nytsz.ag. HL 1133 d/1739 öe.

[56] MN HTP -főnök titkos sorszámos rendelkezések 1988 HL 1131 d./1735 öe.

[57] MN EüSzF-ség titkos sorszámú rendelkezések 1988 NL 1132 d./1736 öe.

[58] Szervezési csoportfőnökség szervezési intézkedések a haderő feladataira (Bakony-III, Gerecse-I) 1989, 1990. MN felsőfokú végzettséghez kötött beosztások nomenklatúrája 1979. HL624 d./912 öe.

[59] A Magyar Néphadsereg negyed százada a rendszerváltástól napjainkig. HM Zrínyi Kiadó 2016, 67-69. o.
Lt. Gen. (ret.) Prof. L. Svéd M.D., PhD

History of the Medical Service

of the Hungarian People's Armed

Forces 1980-1989 (Part II.)

Part I of the comprehensive work has outlined ways of implementation and readiness of the medical service and its preparation and conditions for these tasks. Now, based on contemporary documents, I present memories of those special daily tasks of the medical service that are not part of the mission of other services of the military, namely the organization and management of treatment and preventive care for an increasing number of eligible patients and -for some reasons- the civil population. This period is also significant from this point of view, since long lasting infrastructure investments, and regeneration of the peacetime and wartime equipment park took place during this period. Significant progress has also been made in the development of preventive and research activities, which were indirectly considered part of the preparations for wartime period.

Keywords: Hungarian People's Army, military medicine, military hospitals, medical service, health screening, health education, epidemiology and public higiene, sanatoria of the Hungarian People's Army, scholar, reconstruction, troop level medical units, garrison infirmary, organizational tasks, conditioning

Prof. Dr. Svéd László ny. altbgy. PhD 1134 Budapest, Róbert Károly krt. 44. 